\title{
14. SEDIMENTARY AND DIAGENETIC PROCESSES IN THE CENTRAL PANAMA BASIN SINCE THE LATE MIOCENE: THE LITHOLOGY AND COMPOSITION OF SEDIMENTS FROM DEEP SEA DRILLING PROJECT SITES 504 AND 505 ${ }^{1}$
}

\author{
Helmut Beiersdorf, Bundesanstalt für Geowissenschaften und Rohstoffe, D-3000 Hannover 51, \\ Federal Republic of Germany \\ and \\ James H. Natland, Scripps Institution of Oceanography, La Jolla, California
}

\begin{abstract}
Rapidly deposited Miocene and younger siliceous and calcareous sediments at Sites 504 and 505 in the central Panama Basin near the eastern end of the equatorial high productivity belt exhibit marked lithologic variation with increasing depth. At both sites, the sediments are particularly calcareous just above the basaltic basement and were deposited at the highest accumulation rates. Sediments distinctly lower in carbonate and richer in clayey and siliceous components were deposited in the late Pliocene, a period characterized by lower accumulation rates. The sediments became somewhat more calcareous again in the Pleistocene, when accumulation rates rose again. Accumulation rates at Site 505, which is $77 \mathrm{~km}$ north of Site 504, have been enhanced by redeposition from surrounding basement highs, but the patterns of the accumulation rates at the two sites are similar.

The lithologic variations reflect the sensitive interplay of crustal subsidence, fluctuations in the calcite compensation depth, and changes in the geographic location or the quantity of surface-water productivity. Computations using the bulk sediment composition of samples from Site 504 show that the rate of accumulation of biogenic silica increased nearly fourfold during the upper Pliocene, despite the drop in carbonate and overall accumulation rates. This could be explained by the shoaling of the calcite compensation depth beneath a zone of very high surface productivity, which would increase the carbonate dissolution in the water column but leave biogenic opal comparatively unaffected. Chemical data for the sediments also show a slight enrichment in $\mathrm{Mn}, \mathrm{Fe}, \mathrm{Cu}, \mathrm{Zn}$, and other trace metals at about this time, reflecting increases in both hydrogenous and metalliferous ("hydrothermal") components. The biological fixation of seawater sulfate as pyrite, in combination with the high sediment accumulation rates, probably contributed to the enrichment of some of the trace metals.

Chemical data also show that several of the Pleistocene and one of the lower Pliocene ash beds are rhyolitic in composition and represent material derived from the South American eruption of ignimbrites. In all beds except these, however, bioturbation has dispersed ash to uniform and low abundances in the sediments.

Sites 504 and 505 are in contrasting locations of high and low heat flow, respectively. Temperatures near $50^{\circ} \mathrm{C}$ just above basalts at Site 504 have promoted the formation of chert bands intercalated with limestone in the 30 meters above the basalts and have accelerated the induration of nearly 90 meters of sediments above the cherts to chalk. The thickness of the sediments at Site 505 is similar, but the sediments remain oozes nearly down to basement, where temperatures are only about $9^{\circ} \mathrm{C}$.
\end{abstract}

\section{INTRODUCTION}

During DSDP Legs 68 and 69 a group of holes was drilled at Sites 504 and 505 on the southern flank of the Costa Rica Rift in the Panama Basin. The two sites are $77 \mathrm{~km}$ apart on a nearly north-south line between latitudes $1^{\circ} \mathrm{N}$ and $2^{\circ} \mathrm{N}$ at a longitude of $83^{\circ} 40^{\prime} \mathrm{W}$ (Fig. 1). Sites 504 and 505 differ considerably from one another with regard to seafloor topography, heat flow, and basement age as determined by the magnetic anomaly pattern for this area (Langseth et al., this volume). Site 504, which has a basement age of approximately 5.9 m.y., lies in an area of high heat flow $\left(200-240 \mathrm{~mW} / \mathrm{m}^{2}\right)$ and smooth topography. The basement at the site is completely covered with sediments about $\mathbf{2 6 0}$ meters thick. Site 505 is in an area of lower heat flow (15-100 $\mathrm{mW} / \mathrm{m}^{2}$ ) and rough topography, with many basement outcrops piercing the sediment cover. The basement at this site was formed approximately $3.9 \mathrm{Ma}$.

\footnotetext{
${ }^{1}$ Cann, J. R., Langseth, M. G., Honnorez, J., Von Herzen, R. P., White, S. M., et al., Init. Repts. DSDP, 69: Washington (U.S. Govt. Printing Office).
}

The heat flow at Site 504 is close to that predicted for the conductive cooling of the lithosphere (Langseth et al., this volume). In contrast, the lower heat flow at Site 505 , together with the cropping out of basement nearby, suggests that the open convection of cold seawater through the basement is causing a more rapid cooling of the uppermost lithosphere. Because of these contrasting heat flow regimes, we expected to find a greater degree of diagenetic alteration in the warm area (where the sediments covered the basement) than in the cold area. Therefore, one goal of the drilling was to study the influence of the different temperature regimes on the diagenetic processes within the sediments.

Although DSDP Legs 9 and 16 (Hays et al., 1972 and van Andel, Heath et al., 1973) were partially devoted to studying the geological history of the Panama Basin, neither leg drilled in the central part of the basin on ocean crust generated at the Galapagos Spreading Center. Therefore, the other goal of drilling the sediments at Sites 504 and 505 was to provide information on the paleoenvironmental development of this area. The Panama Basin is of particular interest because it underlies a 


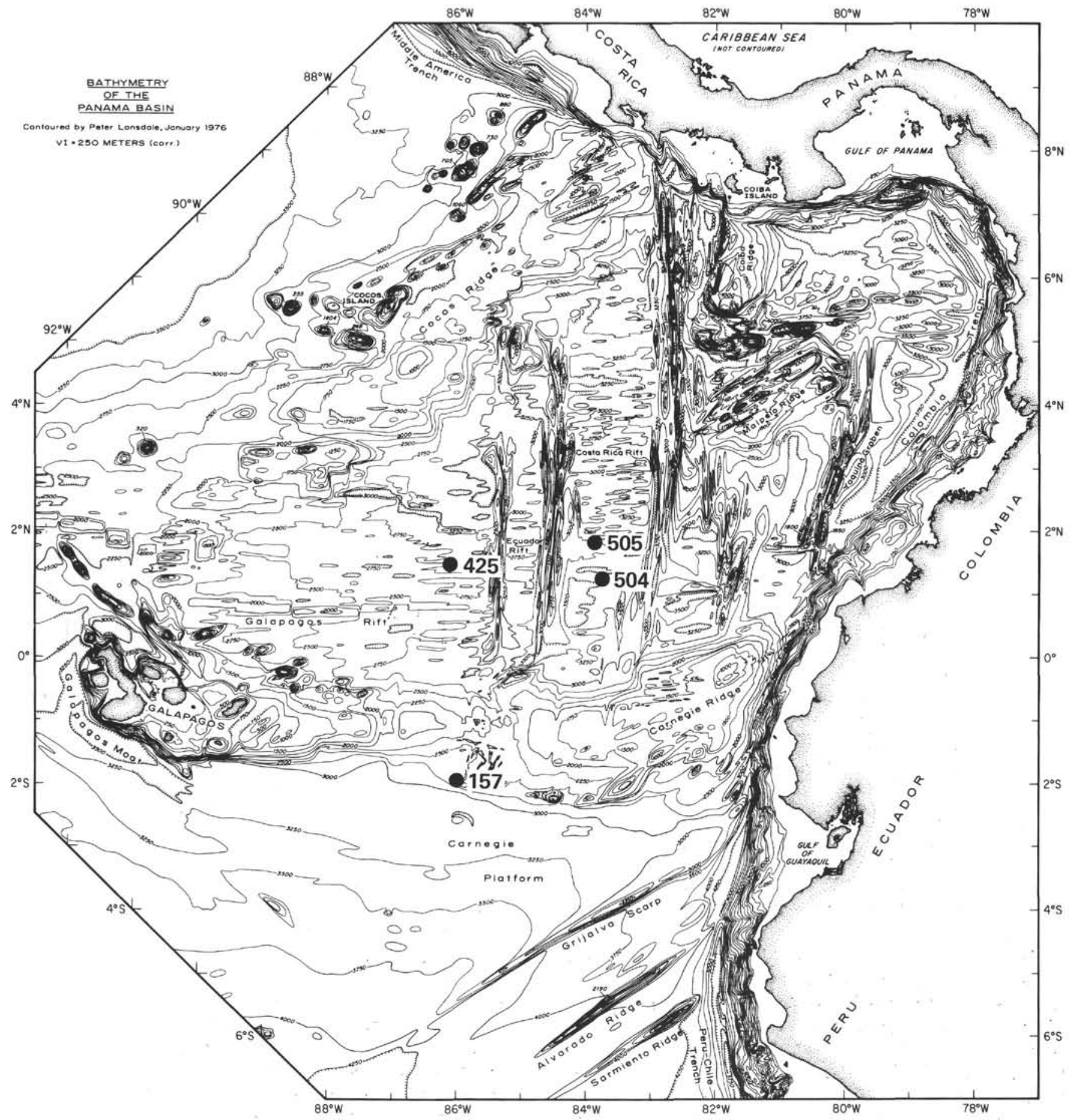

Figure 1. Location of Sites 504 and 505 in the Panama Basin south of the Costa Rica Rift. Bathymetry from Lonsdale and Klitgord (1978). Contour interval is $250 \mathrm{~m}$. Also shown are Sites 157 and 425.

zone of high biological productivity in the seawater associated with the Peru Current and the equatorial divergence (Moore et al., 1973). The water depths of the area (3400-3600 m) are greater than the calcite compensation depth, and calcareous microfossils, though poorly preserved, can still be used (together with siliceous microfossils) for biostratigraphic, paleoenvironmental, and diagenetic studies.
To attain these goals we studied sediments from the following holes: Hole 501 (which was spot cored to basement by the rotary coring technique), Hole 504 (which was continuously hydraulic piston cored until cherts were reached), and Holes 504A, 504B, and 505 (all of which were rotary piston cored). Holes 501 and 504A were continuously cored from the top of cherts into basement. Hole 505 has two uncored intervals where 
heat flow measurements were undertaken $(85-95 \mathrm{~m}$ and 143-153 m sub-bottom), but basaltic basement was reached without encountering cherts.

\section{METHODS}

This study is based on structural and textural descriptions, determinations of the components of the sediments, and $\mathrm{CaCO}_{3}$ content carried out on board ship, shore-based coarse fraction analyses, and major-oxide and trace-element analyses undertaken during and after the cruise. Sedimentary structures were analyzed visually when the cores were split. The texture and bulk composition of unconsolidated sediments were determined from smear slides that were prepared at a sampling rate of one per section (or more when necessary). We studied the texture and composition of consolidated sediments by using thin sections of selected intervals. The "Karbonat-Bombe" (Müller and Gastner, 1971) was used to measure $\mathrm{CaCO}_{3}$.

The coarse fraction analyses are based on 257 samples from Holes 504 and 505. Most of the sections that contained unconsolidated sediment were sampled. The samples were separated by wet sieving into the grain-size fractions $<32 \mu \mathrm{m}, 32$ to $63 \mu \mathrm{m}$, and $>63 \mu \mathrm{m}$. The fractions were then dried in an oven and weighed, and the proportion each made up of the sediment was calculated. Strewn slides from split samples of the coarse fraction $(>63 \mu \mathrm{m})$ were prepared, and the percentages of individual components were calculated from the results of a grain-by-grain line count (300-500 grains per slide).

The weight percentages of the fractions 32 to $63 \mu \mathrm{m}$ and $>63 \mu \mathrm{m}$ as well as the "grain percentages" of components relevant to diagenesis and sedimentation history were averaged for each core for Hole 504 and for the upper and lower three sections of each core for Hole 505 and plotted versus depth. To permit the graphic presentation of the grain-size distribution, weight percentages of the fractions 32 to $63 \mu \mathrm{m}$ and $>63 \mu \mathrm{m}$ are combined in the figures with visual estimates from the smear slides of the size of the clay-sized fraction.

Shipboard and shore-based chemical analyses were performed by $\mathrm{X}$-ray fluorescence spectroscopy (XRF) for both major oxides and trace elements.

All stratigraphic correlations within the sedimentary sequences are based on the diatom biostratigraphy (Sancetta, this volume). The ages of the sediment basalt contacts at both sites were derived from the ages of the magnetic anomalies: 5.9 Ma at Site 504 and 3.9 Ma at Site 505 (Langseth et al., this volume).

Descriptions of the lithostratigraphy of the sediments recovered at Sites 504 and 505 are given in the site chapters. This chapter provides graphic synopses of the general lithostratigraphic descriptions and additional information (Tables 1-10 and Figs. 2-12) and interpretation that are based on all shipboard and shore-based observations and measurements.

\section{SEDIMENTOLOGY OF SITE 504}

\section{Lithologic Units}

The sediments cored at Site 504 consist of three lithologic units (Fig. 2). Unit I, at 0 to 143.50 meters sub-bottom, is made up of upper Pleistocene to lower Pliocene siliceous nannofossil and nannofossil radiolarian oozes and is variably clay bearing. Unit II, at 143.50 to 227.20 meters sub-bottom, is lower Pliocene to upper Miocene siliceous nannofossil chalk. Unit III, at 227.20 to 271 meters sub-bottom, consists of upper Miocene interbedded nannofossil chalk, limestone, and chert. This division is based on sharp diagenetic boundaries (ooze-chalk-limestone). Lithologic Unit I is divided into three subunits because a zone with dark to very dark grayish brown layers appears at depths between 65 and 99 meters subbottom. The subunits are as follows. Subunit Ia, at 0 to 65 meters sub-bottom, is upper to lower Pleistocene nannofossil radiolarian ooze, sometimes clay bearing. Subunit Ib, at 65 to 99 meters sub-bottom, is lower Pleistocene to upper Pliocene clay-bearing nannofossil radio- larian ooze. Subunit Ic, at 99 to 143.50 meters sub-bottom, is upper to lower Pliocene clay-bearing siliceous nannofossil ooze.

\section{Sedimentary Structures}

In the ooze and chalk units, simple beds with sharp boundaries (i.e., primary structures as defined by Bouma, 1975) occur only as ash layers. Ash layers appear at $12.25,14.95,28.75,173,183.40$, and 187.36 meters subbottom (Fig. 2). The thickness of the ash beds ranges from 2 to $13 \mathrm{~cm}$. In the remaining sediments of Lithologic Units I and II, changes in color, $\mathrm{CaCO}_{3}$ content, bulk composition, and grain-size distribution are gradual and probably reflect gradational changes in deposition. Intense bioturbation, in evidence as numerous burrows (secondary structures), has probably destroyed most sharp boundaries between layers. The sharp boundaries of the ash layers suggest that sudden input of volcanic material prevented mixing by benthic organisms.

The frequency of color changes in Lithologic Units I and II decreases with depth (Fig. 2). The most frequent color layering occurs between 10 and 30 meters sub-bottom, where there are 12 layers, and between 50 and 90 meters sub-bottom, where there are 24 layers.

The low frequency of the color changes in the lower part of Lithologic Unit I and throughout Lithologic Unit II may be a consequence of weaker fluctuations in the supply of detrital and ashy materials as well as of the difficulty of distinguishing slight color changes in the intensely mottled light gray, light green, and pale green shades that characterize sediments with high carbonate content.

Zoophycos burrows, among others, are prominent in Lithologic Unit I but are less common in its clay-rich intervals (Fig. 2). They cannot be seen in Lithologic Unit II, probably because the lack of strong color contrasts prevents their recognition. Zoophycos burrows occur again in the limestones of Lithologic Unit III, where they are vertically compressed and were possible to use to determine the degree of vertical compaction (Plate 1). Since the sediments of Lithologic Unit III originated from the same types of materials as the sediments of Lithologic Unit II, it is logical to expect Zoophycos burrows to be there as well.

Another prominent feature of the bioturbation is the appearance of large vertical burrows. These burrows occur in Subunits Ia and Ib, as well as in the upper part of Lithologic Unit II, in intervals where color changes are frequent (Fig. 2).

Large, light-colored burrow halos with purple margins are abundant in the lowermost part of Lithologic Unit I and throughout Lithologic Unit II (Fig. 2). The halos may indicate an early diagenetic mobilization, probably of manganese, which, under reducing conditions, migrates from the inner microenvironment of burrows toward their outer zones (Hartmann, 1979).

The sedimentary rocks in Lithologic Unit III (cherts, limestones, and silicified limestones) are finely laminated or bedded ( $\mathrm{mm}$ to $\mathrm{cm}$ scale) and thus show abrupt changes in composition (Plate 1). Occasionally, the laminae or thin beds terminate at one side (are wedge- 
Hole 504

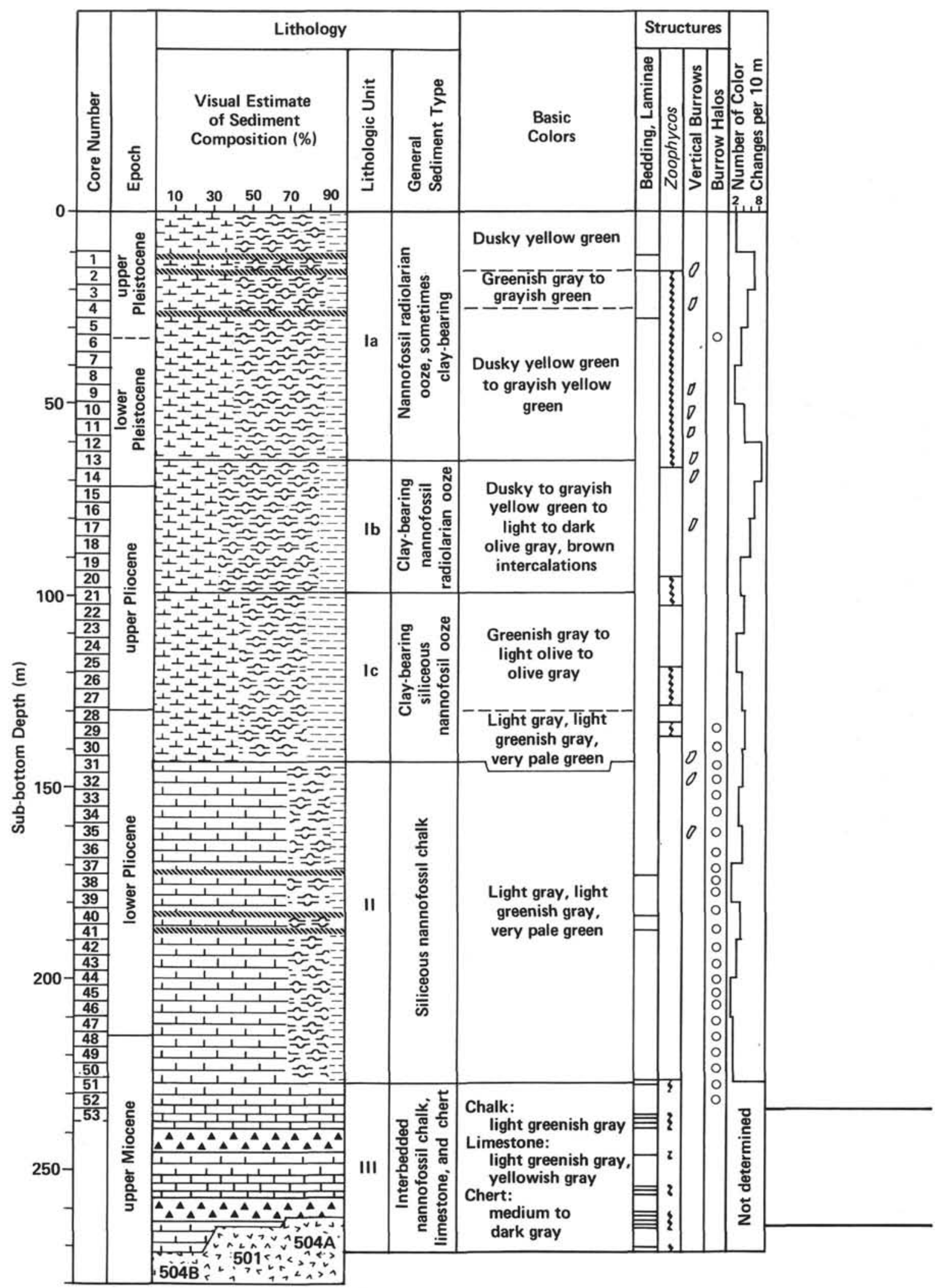

Figure 2. Lithologic summary of Site 504. Given are age, lithology, color, and sedimentary features versus depth and core number. Intervals with cherts in Holes 501, 504A, and 504B are expanded on the right to show the sequence of rock types cored in each hole. 


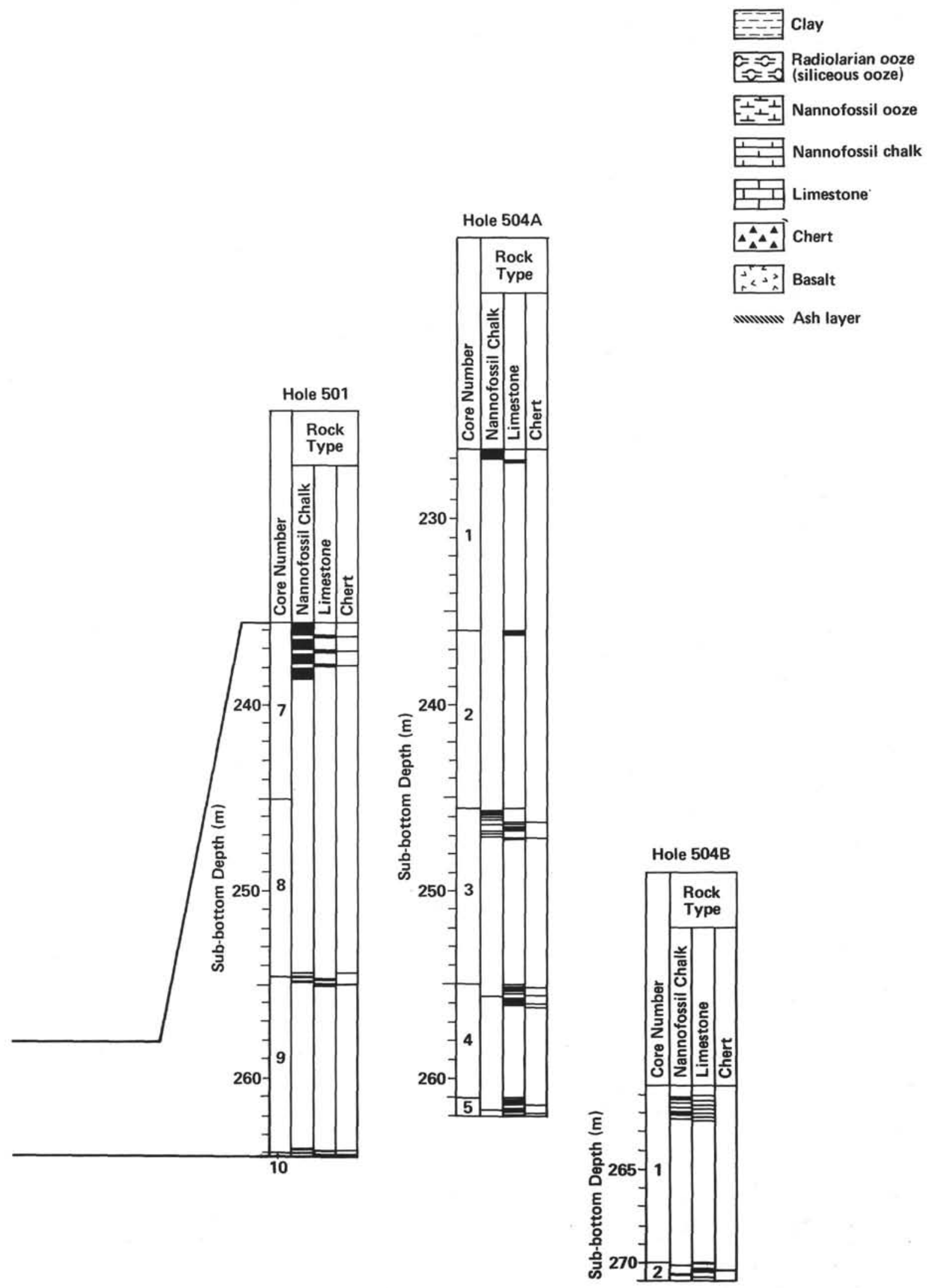

Figure 2. (Continued). 
shaped) or at two sides (are lenticular). The wedgeshaped beds may represent only one side of a bisected lenticular structure. Some of the smaller lenticular shapes may be cross sections of burrows. The compressed Zoophycos burrows sometimes cross cut or penetrate each other or bedding planes. The beds also contain microfossils and pyrite, often in concentrations that run parallel to the laminae. The origin of the fossil inclusions is syn-sedimentary, and that of the pyrite is postsedimentary and authigenic.

Other structural features in Lithologic Unit III are irregular bodies and nodules of chert or porcellanite (Plate 2, Figs. 1 and 2). They are a result of $\mathrm{SiO}_{2}$ mobilization and migration within the sediments; thin sections show that opal-CT lepispheres and quartz have been deposited within foraminifer chambers (Plate 2, Figs. 3 and 4; see also Hein et al., this volume).

\section{Grain-Size Distribution}

Grain-size data for the unconsolidated sediments at Site 504 are listed in Table 1 and shown in Figure 3. The size of the clay-sized fraction $(<2 \mu \mathrm{m})$ is a visual estimate from smear slides and is therefore less accurate than the size of the coarse silt (32-63 $\mu \mathrm{m})$ and sand-sized ( $>63 \mu \mathrm{m}$ ) fractions, which were measurements of weight. Settling-tube tests on some samples show that the size of the clay-sized fraction is consistently underestimated optically and that the actual clay content of a sample is approximately $50 \%$ higher than the estimate.

The clay-sized fraction consists of clay minerals (mainly smectite) and other very fine minerals, such as quartz and feldspar, as well as of very fine, mostly siliceous fossil debris. Intervals occur at depths from 65 to 80 and from 100 to 120 meters sub-bottom (in Subunits Ib and Ic) that are rich in clay-sized material, with values up to 35 and $48 \%$, respectively. All other parts of the unconsolidated sediment sequence have clay-sized percentages of $10 \%$ or less.

The proportion of the sediment that is fine to medium-sized silt (2-32 $\mu \mathrm{m})$ depends to a great extent on the size of the clay-sized fraction, since the fraction larger than $32 \mu \mathrm{m}$ is generally small and shows little variation. Accordingly, the proportion of fine to medium-sized silt decreases to $45 \%$ in the clay-rich intervals. In the rest of the sequence it varies between 70 and $90 \%$.

The percentage of the coarse silt fraction generally decreases with depth from about $10 \%$ within the top 20 meters sub-bottom to less than $5 \%$ below 215 meters sub-bottom. There is an exception between 170 and 180 meters sub-bottom, where values again reach $10 \%$.

The percentage of the sand-sized fraction rarely exceeds $10 \%$ and also decreases with depth. The randomly distributed measurements of higher percentages are caused by layers rich in foraminifers, volcanic glass, or sediment pellets (it is unclear whether the pellets were artificially produced by the sieving process or are natural, produced by burrowing animals). Very low percentages ( $1 \%$ or less) occur below 150 meters sub-bottom.

The silt- and sand-sized fractions are composed mainly of calcareous and siliceous microfossils, such as nannofossils, foraminifers, radiolarians, diatoms, and fragments of these components. Minor but significant com-
Table 1. Grain-size distribution for sediments at Hole 501 (Core 1) and Hole 504.

\begin{tabular}{|c|c|c|c|}
\hline Hole/Core & $\begin{array}{c}\text { Clay }(<2 \mu \mathrm{m}) \\
(\%)^{\mathrm{a}}\end{array}$ & $\begin{array}{c}\text { Coarse Silt } \\
(32-63 \mu \mathrm{m}) \\
\text { (wt. } \%)\end{array}$ & $\begin{array}{c}\text { Sand }(>63 \mu \mathrm{m}) \\
(\mathrm{wt} . \%)\end{array}$ \\
\hline \multicolumn{4}{|l|}{501} \\
\hline 1 & 12 & 9.6 & 7.5 \\
\hline \multicolumn{4}{|l|}{504} \\
\hline 1 & 12 & 10.9 & 7.4 \\
\hline 2 & 8 & 3.9 & 2.8 \\
\hline 3 & 15 & 4.8 & 6.3 \\
\hline 4 & 8.5 & 4.4 & 4.6 \\
\hline 5 & 9 & 3.3 & 3.7 \\
\hline 6 & 9.5 & 5.3 & 5.3 \\
\hline 7 & 7.5 & 6.2 & 4.2 \\
\hline 8 & 12 & 6.5 & 7.6 \\
\hline 9 & 15 & 3.9 & 4.3 \\
\hline 10 & 10 & 4.8 & 10.5 \\
\hline 11 & 13 & 5.5 & 5.5 \\
\hline 12 & 11.5 & 3.3 & 5.2 \\
\hline 13 & 14 & 4.1 & 4.6 \\
\hline 14 & 23 & 4.4 & 3.4 \\
\hline 15 & 15 & 3.7 & 20.8 \\
\hline 16 & 35 & 5.2 & 4 \\
\hline 17 & 10 & 6.4 & 5.3 \\
\hline 18 & 2 & 4 & 3 \\
\hline 19 & 4 & 3.5 & 3.1 \\
\hline 20 & 1 & 4 & 3.6 \\
\hline 21 & 24 & 3.5 & 2.6 \\
\hline 22 & 43 & 2.7 & 2.3 \\
\hline 23 & 40 & 5 & 2 \\
\hline 24 & 48 & 3 & 2 \\
\hline 25 & 32 & 4.4 & 5.1 \\
\hline 26 & 7 & 5.1 & 3 \\
\hline 27 & 14 & 4.6 & 2 \\
\hline 28 & 10 & 3.5 & 2.8 \\
\hline 29 & 10 & 4.3 & 2.2 \\
\hline 30 & 15 & 4.7 & 3 \\
\hline 31 & 13 & 4 & 2.4 \\
\hline 32 & 11 & 4.1 & 2.2 \\
\hline 33 & 11 & 4.4 & 1.4 \\
\hline 34 & 12 & 6.3 & 3.2 \\
\hline 35 & 11 & 4.7 & 4.9 \\
\hline 36 & 10 & 5.7 & 7.9 \\
\hline 37 & 11 & 4.7 & 2.4 \\
\hline 38 & 5 & 9.9 & 6.1 \\
\hline 39 & 5 & 3.8 & 1.4 \\
\hline 40 & 8 & 4.3 & 3.2 \\
\hline 41 & 8 & 5.1 & 2.1 \\
\hline 42 & 5 & 3.5 & 1.9 \\
\hline 43 & 8 & 3.9 & 1.9 \\
\hline 44 & 13 & 4.3 & 2.8 \\
\hline 45 & 10 & 4.2 & 4.2 \\
\hline 46 & 15 & 3 & 1.5 \\
\hline 47 & 15 & 3.6 & 6.1 \\
\hline 48 & 13 & 3.8 & 1.9 \\
\hline 49 & 12 & 3.9 & 2.3 \\
\hline 50 & 12 & 2.6 & 1.8 \\
\hline 51 & 12 & 3.4 & 1.5 \\
\hline 52 & 12 & 3.7 & 1.8 \\
\hline 53 & 5 & 4.4 & 5.1 \\
\hline
\end{tabular}

a Visual estimate.

ponents are sponge spicules, silicoflagellates, silicic volcanic glass, pyrite, and sediment pellets.

The grain-size distribution within the nannofossil chalk beds of Lithologic Unit III is approximately the same as in the lowermost part of Lithologic Unit II. The 
limestones of Lithologic Unit III have a matrix that consists of about $80 \%$ clay-sized grains of unspecified carbonate, $15 \%$ silt-sized material, and $5 \%$ sand-sized material. The silt- and sand-sized material is made up mainly of foraminifers, their fragments, and pyrite.

\section{Smear Slide Summary}

Smear slide data for Site 504 sediments are presented in Table 2 and Figure 3. The siliceous biogenic fraction in Figure 3 is not subdivided because diatoms were often covered by siliceous fossils of optically higher relief, suggesting that they are underrepresented compared with radiolarians, and because silicoflagellates and sponge spicules occur in minor amounts only (Table 2). Miscellaneous fossil groups and minerals were counted collectively and entered under "other components" in Figure 3 and Table 2. Among these components are echinoderm spicules, ostracodes, lamellibranchs, fish remains, pellets, volcanic glass, quartz, feldspar, and pyrite. Volcanic ash layers are excluded from this summary.

Within the calcareous biogenic fraction, nannofossils are the dominant constituent; they always exceed the proportions of foraminifers and unspecified carbonate (mainly foraminifer fragments). Relatively low percentages of less than $30 \%$ are only found at the top of Lithologic Unit I and in the clay-rich intervals of Subunits Ib and Ic. The highest nannofossil proportions occur at the base of Lithologic Unit II, where they sometimes exceed $70 \%$. However, the distinction between fragmented nannofossils and unspecified carbonate grains is often difficult to make. Therefore, some of the nannofossil fraction may be unspecified carbonate. Between the extremes of 30 and $70 \%$, the nannofossil percentages range mainly between 40 and $60 \%$.

Foraminifers occur in various stages of preservation. Benthic foraminifers rarely exceed $2 \%$ of the total foraminifer assemblages, except in the lowermost part of Lithologic Unit II, where they may be as much as $25 \%$ of all foraminifers. From the top of the sediment sequence toward the base of Subunit Ia the foraminifer abundance decreases from $20 \%$ to trace abundances. Below 60 meters sub-bottom, the percentages rarely exceed $5 \%$. At the boundary between Subunits Ib and Ic foraminifers make up $10 \%$ of the sediment composition. Coarse fraction analysis also shows that samples from this part of the sequence have significantly higher foraminifer percentages (Fig. 4) and therefore seem to reflect a short-term change in the depositional regime (see discussion below of changes in accumulation rates between 2.5 and $2.0 \mathrm{Ma}$ ). Between the top of the sediment sequence and the base of Subunit Ib the percentages of unspecified carbonate fluctuate between 3 and $15 \%$. From the top to the middle of Subunit Ic they are less than $3 \%$. Below this interval to a depth of 180 meters sub-bottom, there is a general increase up to $35 \%$. Below this depth the unspecified-carbonate percentages decrease again, but they are never lower than $5 \%$.

Within the siliceous fossil fraction the percentages of diatoms exceed those of radiolarians (Table 2), but each of these fossil groups forms a significantly larger portion than sponge spicules and silicoflagellates, which to- gether form a fraction that is rarely greater than $10 \%$. Sponge spicules are generally more common than silicoflagellates. In Lithologic Unit I the percentages of siliceous fossils mainly range between 20 and $40 \%$ without any significant trend. They are always lower than $30 \%$ in Lithologic Unit II, except at the base of Lithologic Unit II (226.5-337 m sub-bottom), where diatom abundance in individual samples is sometimes as much as $40 \%$.

The distribution of clay percentages is almost identical to that of the clay-sized fraction, which is discussed in the section on grain-size distribution.

Silicic volcanic glass, mainly rhyolitic, and authigenic pyrite, which dominate the percentages of the fraction "other components" in Table 2, are consistently present to a depth of 210 meters sub-bottom. Below this depth they are randomly distributed. The volcanic glass is more common in Lithologic Unit I than in Lithologic Unit II, where the glass content of the sediments is enhanced only in the vicinity of the ash layers.

Pyrite is most common in Subunits Ib and Ic. The high percentage of the fraction "other components" at 87.20 meters sub-bottom (Fig. 2) is caused by a layer sampled in Core 18 that consists of $30 \%$ pyrite. Most of the pyrite found occurs as small spheroids or framboids, which are often concentrated around burrows, or as fossil coatings (Plate 3, Figs. 1-3). One solid layer of large $(>100 \mu \mathrm{m})$ pyrite crystals occurs at 231.30 meters subbottom (Plate 3, Figs. 4-9).

Chitinous copepod fragments (Plate 3, Fig. 10) are restricted to the uppermost sediments. All other minor components are randomly distributed.

Overall, fluctuations in composition between samples are particularly strong between 10 and 30 meters subbottom and between 50 and 90 meters sub-bottom (Subunits $\mathrm{Ia}$ and $\mathrm{Ib}$ ). Color changes are also frequent in these intervals.

\section{Calcium Carbonate Content}

Calcium carbonate $\left(\mathrm{CaCO}_{3}\right)$ percentages from the "Karbonat Bombe" are presented in Table 3 and Figure 3. The $\mathrm{CaCO}_{3}$ curve shows the same general trend as the curve in Figure 3 for the calcareous biogenic fraction estimated from the smear slides (foraminifers + unspecified carbonate + calcareous nannofossils). However, differences in the absolute percentages can be considerable if the curves are compared on a core-by-core basis. The differences are probably caused by uncertainty in the percentages of the calcareous components, which were estimated from smear slides, and by differences between sampling points.

The major declines in $\mathrm{CaCO}_{3}$ content (down to $10 \%$ ) occur in Subunits $\mathrm{Ib}$ and $\mathrm{Ic}$ and correspond to clay-rich intervals. A relatively substantial increase in $\mathrm{CaCO}_{3}$ content occurs within the ooze-chalk transition zone. Below this zone the proportion of calcium carbonate continues to increase moderately, and at the base of Lithologic Unit II it represents 70 to $80 \%$ of the sediment. In Subunit Ia the $\mathrm{CaCO}_{3}$ curve deviates more from the smear slide estimates of calcareous biogenic material than in other parts of the sequence. This seems 
Hole 504
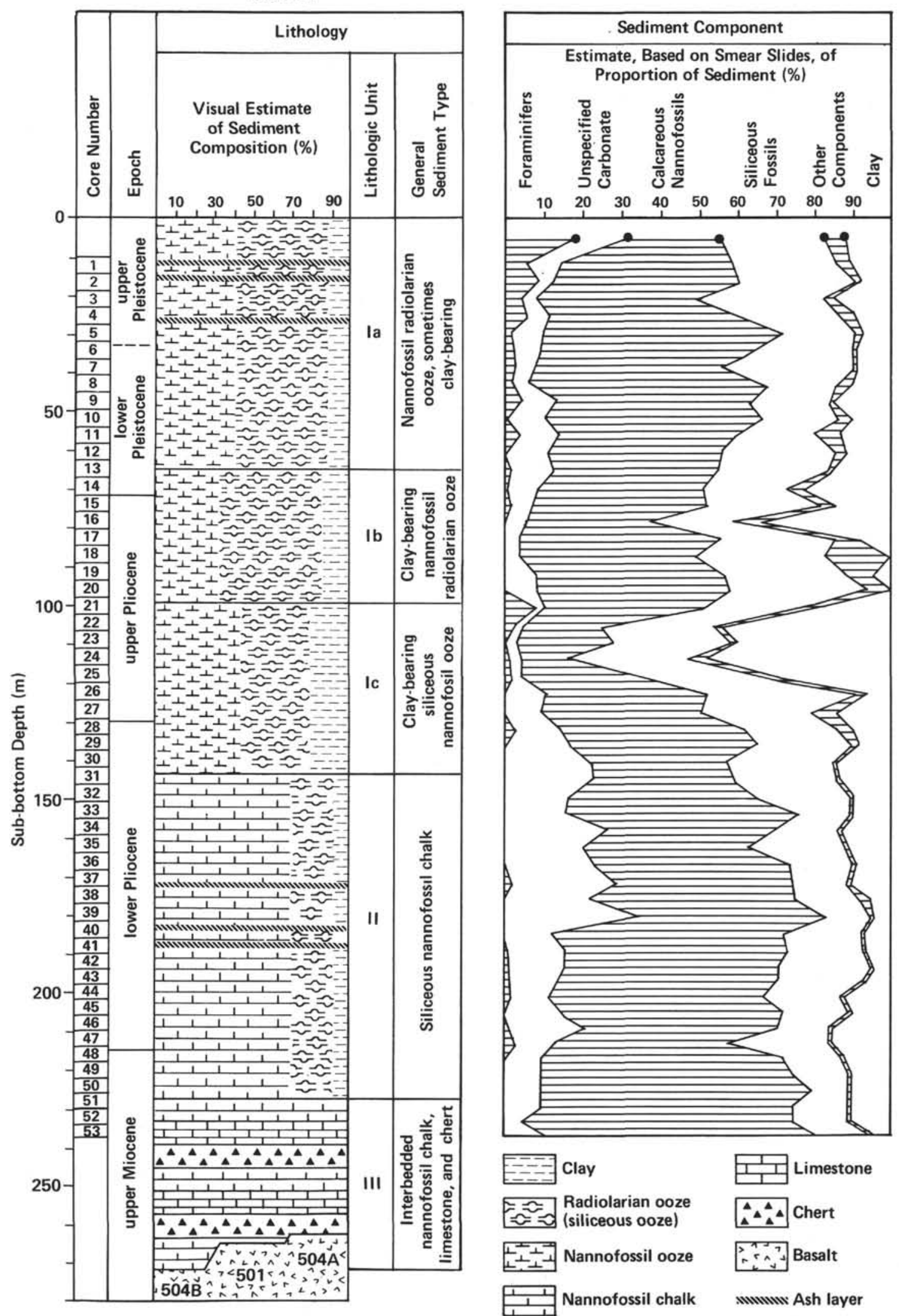

Figure 3. Composition, texture, and calcium carbonate content of the unconsolidated sediments of Hole 504 and Hole 501 (Core 1). Shading is used to augment distinctions between compositional components. 

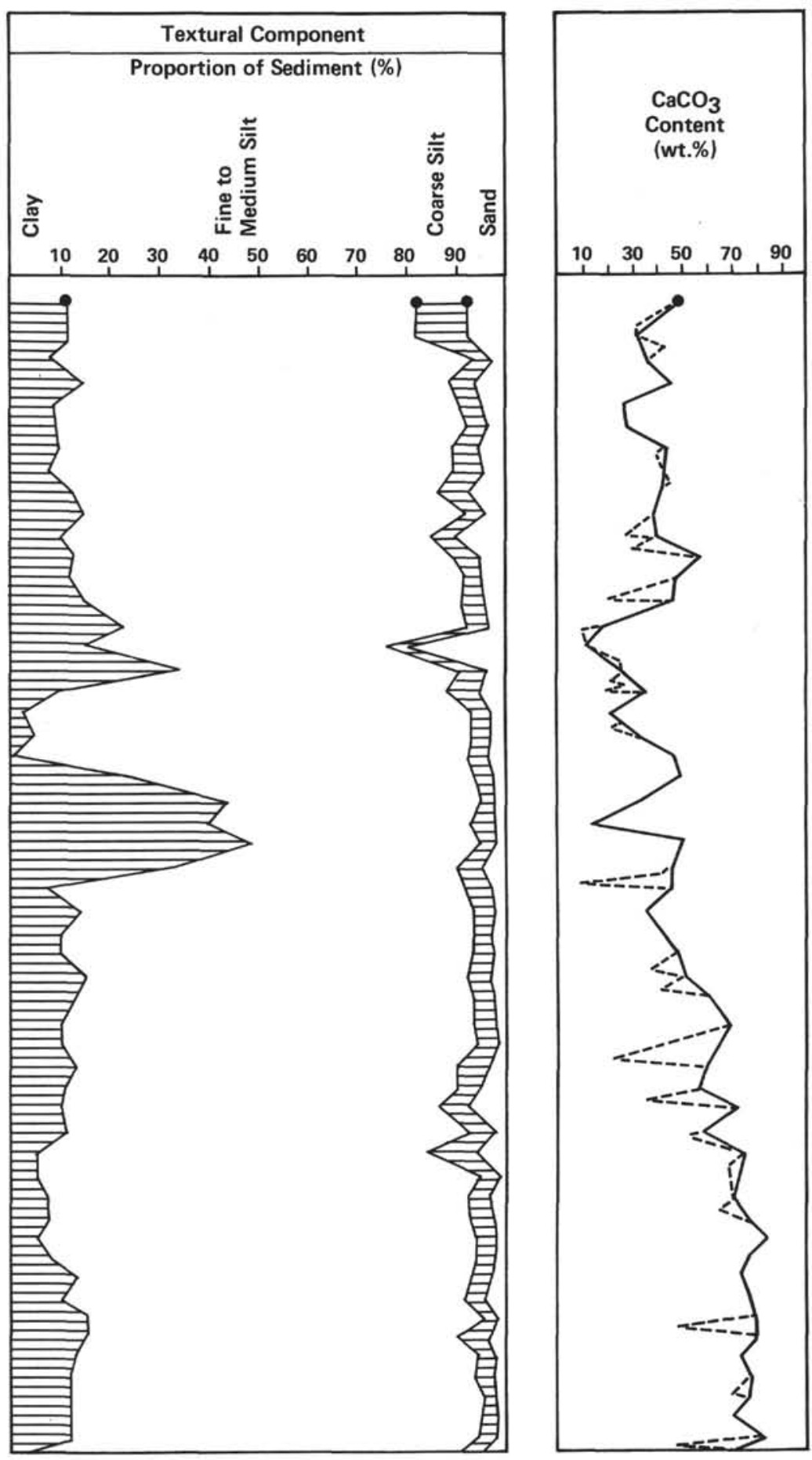

- Data from Hole 501

$\mathrm{CaCO}_{3}$ content determined by "Karbonat Bombe"

- $\mathrm{CaCO}_{3}$ content determined by chemical analysis

Figure 3. (Continued). 
Table 2. Smear slide abundances in sediments from Hole 501 (Core 1) and Hole 504.

\begin{tabular}{|c|c|c|c|c|c|c|c|c|c|c|}
\hline Hole/Core & $\begin{array}{c}\begin{array}{c}\text { Foramin- } \\
\text { ifers }\end{array} \\
\end{array}$ & $\begin{array}{l}\text { Unspecified } \\
\text { Carbonate }\end{array}$ & $\begin{array}{c}\text { Calcareous } \\
\text { Nannofossils }\end{array}$ & $\begin{array}{l}\text { Radio- } \\
\text { larians }\end{array}$ & Diatoms & $\begin{array}{c}\text { Silico- } \\
\text { flagellates }\end{array}$ & $\begin{array}{c}\text { Sponge } \\
\text { Spicules }\end{array}$ & $\begin{array}{c}\text { Total } \\
\text { Siliceous } \\
\text { Fossils } \\
\end{array}$ & $\begin{array}{c}\text { Other } \\
\text { Components }\end{array}$ & Clay \\
\hline & \multicolumn{10}{|c|}{ Average Abundance per Core $(\%)$} \\
\hline 501 & & & & & & & & & & \\
\hline 1 & 18.5 & 13 & 23.5 & 8.2 & 12 & 5.3 & 1.5 & 27 & 6 & 12 \\
\hline \multicolumn{11}{|l|}{504} \\
\hline 1 & 5.2 & 8.6 & 44.8 & 11 & 11 & 3.2 & 1.4 & 26.6 & 5.8 & 10.4 \\
\hline 2 & 8.2 & 3.2 & 48.8 & 8 & 17.5 & 1 & 3 & 29.5 & 5.1 & 8.2 \\
\hline 3 & 4.6 & 3 & 41.4 & 11 & 11.4 & 4 & 6.2 & 32.6 & 9.2 & 15.4 \\
\hline 4 & 5.8 & 5.3 & 51.3 & 11.8 & 13 & 2.5 & 2.3 & 29.6 & 6.3 & 9.3 \\
\hline 5 & 1.5 & 8 & 62.5 & 7.3 & 7.8 & 1.8 & 1 & 17.9 & 3.8 & 7.3 \\
\hline 6 & 2.3 & 6.7 & 55.7 & 10 & 10 & 2.3 & 2.7 & 25 & 3.3 & 9.7 \\
\hline 7 & 2.7 & 5 & 48.3 & 12.3 & 13.3 & 5 & 3.3 & 33.9 & 4.4 & 9 \\
\hline 8 & 2 & 4.3 & 59.3 & 6 & 6.5 & 3 & 2.5 & 18 & 8.9 & 10 \\
\hline 9 & 4 & 8.3 & 50.3 & 6.7 & 7.7 & 3.7 & 3.7 & 21.8 & 4.3 & 15 \\
\hline 10 & $\mathrm{Tr}$ & 10 & 56.3 & 6.3 & 6.3 & 2 & 4.7 & 19.3 & 9.1 & 10 \\
\hline 11 & 3.7 & 10 & 46 & 10 & 10 & 4.7 & 5 & 19.7 & 2.3 & 13.3 \\
\hline 12 & $\mathrm{Tr}$ & 11 & 45 & 9.2 & 12.8 & 3.2 & 4 & 29.2 & 6.8 & 12 \\
\hline 13 & 1.4 & 10.4 & 42.4 & 9.6 & $\begin{array}{l}13.8 \\
\end{array}$ & 2.4 & 3 & 28.8 & 4 & 16 \\
\hline 14 & 0.6 & 7.4 & 42.4 & 7.2 & 9 & 2.6 & 2.8 & 21.6 & 8.2 & 22.6 \\
\hline 15 & 1.7 & 5.7 & 44.7 & 8 & 12 & 3.7 & 5.3 & 29. & 3.9 & 15 \\
\hline 16 & - & 6 & 31 & 6.7 & 7 & 3 & 5.3 & 22 & 6 & 35 \\
\hline 17 & - & 3.7 & 57.7 & 8.3 & 11.6 & 8.3 & 1.7 & 29.9 & $\mathrm{Tr}$ & 8.3 \\
\hline 18 & - & 4 & 45 & 10 & 13.8 & 6.3 & 3.8 & 33.9 & 17.1 & - \\
\hline 19 & - & 8.3 & 48.3 & 10 & 13.3 & 6.3 & 1.7 & 31.3 & 7.1 & 5 \\
\hline 20 & - & 8.3 & 50 & 10.7 & 11.7 & 10 & 3.3 & 35.7 & 6 & - \\
\hline 21 & 8.7 & 2 & 41 & 7.7 & 11.7 & 4.3 & 3 & 26.7 & 3.6 & 20 \\
\hline 22 & 2 & 3 & 20 & 10 & 12.5 & 3 & 3 & 28.5 & 5.5 & 44 \\
\hline 23 & - & 3 & 25 & 10 & 10 & 6 & 5 & 31 & 1 & 40 \\
\hline 24 & 1 & 3 & 12 & 11 & 11 & 7 & 2 & 31 & 7 & 48 \\
\hline 25 & 1.7 & 3.3 & 29.3 & 11 & 15 & 4.7 & 2.7 & 33.4 & 5 & 30 \\
\hline 26 & $\mathrm{Tr}$ & 10.6 & 41.7 & 13.3 & 15 & 3.7 & 8.3 & 40.3 & 9.7 & 6 \\
\hline 27 & $\mathrm{Tr}$ & 9.5 & 40.8 & 9.5 & 12.5 & 4.5 & 6.5 & 28.5 & 9 & 14.2 \\
\hline 28 & 2.5 & 12.5 & 47.5 & 8 & 8.5 & 2.5 & 5 & 24 & 8.5 & 10 \\
\hline 29 & $\mathrm{Tr}$ & 16.7 & 48.3 & 7.7 & 9 & 3 & 4.7 & 24.4 & 77 & 8.3 \\
\hline 30 & $\mathrm{Tr}$ & 22.5 & 34.7 & 8.8 & 8.8 & 3.3 & 6.8 & 27.7 & 6.9 & 15 \\
\hline 31 & - & 23.3 & 35.7 & 9 & 9.3 & 2 & 6.7 & 27 & 7.4 & 13.3 \\
\hline 32 & - & 16.7 & 48.3 & 7 & 7.7 & 3.3 & 6.7 & 24.7 & 7 & 10 \\
\hline 33 & - & 16 & 60.2 & 5.8 & 4.2 & 1.1 & 2.6 & 13.7 & 2.7 & 10 \\
\hline 34 & - & 26.7 & 43.3 & 5 & 6.3 & 2 & 3.3 & 16.6 & 3.4 & 13.3 \\
\hline 35 & - & 20.3 & 42.3 & 10 & 10 & 1.7 & 4 & 25.7 & 4 & 11.7 \\
\hline 36 & - & 23.3 & 50 & 6 & 8.3 & 1.3 & 2.3 & 17.9 & 1.1 & 10 \\
\hline 37 & 1.7 & 28.3 & 45 & 4.7 & 5.7 & 2 & 1.7 & 14.1 & 4.3 & 10 \\
\hline 38 & - & 21.7 & 53.3 & 5.7 & 7 & 2 & 2 & 16.7 & 3.6 & 6.7 \\
\hline 39 & $\bar{z}$ & 35 & 48 & 5 & 5 & 1 & 1 & 12 & 1.0 & $\begin{array}{l}0.1 \\
5\end{array}$ \\
\hline 40 & - & 12.5 & 60 & 6.5 & 9 & $i$ & 3.5 & 20 & 3.5 & 7.5 \\
\hline 41 & 1 & 15 & 57.2 & 6.6 & 8.6 & 2 & 2.5 & 19.7 & 2.6 & 8 \\
\hline 42 & 1 & 15 & 55 & 7.5 & 9 & 5 & 2.5 & 24 & 3.5 & 5 \\
\hline 43 & 1.3 & 12.7 & 56.7 & 7.3 & 8.3 & 3 & 3.5 & 22.1 & 3.7 & 8.3 \\
\hline 44 & 1.7 & 10 & 5.5 & 7.3 & 9.3 & 3.3 & 1 & 20.9 & 1.4 & 13.3 \\
\hline 45 & - & 15 & 57.5 & 4.5 & 8.5 & 2 & 4.5 & 17.5 & 4.5 & 10 \\
\hline 46 & 1 & 20 & 50 & 4 & 5 & 3 & 2 & 14 & 3 & 15 \\
\hline 47 & 3 & 10 & 45 & 8 & 10 & 4 & 5 & 27 & 8 & 15 \\
\hline 48 & - & 10 & 62 & 5.5 & 8 & 1 & 1.5 & 16 & 1 & 12.5 \\
\hline 49 & - & 10 & 65 & 5 & 8 & 1 & 1 & 15 & 1 & 10 \\
\hline 50 & - & 10 & 70 & 2 & 2 & $i$ & 5 & 10 & 5 & 10 \\
\hline 51 & - & 10 & 65 & 3 & 6 & 1 & 5 & 15 & 5 & 10 \\
\hline 52 & - & 5 & 70 & 5 & 7 & i & 2 & 15 & 2 & 10 \\
\hline 53 & - & 10 & 70 & 4 & 8 & 1 & 2 & 15 & 2 & 5 \\
\hline
\end{tabular}

to be a consequence of the rapidity of the fluctuations in composition in the intervals from 10 to 30 meters subbottom and from 50 to 90 meters sub-bottom, which exaggerates the discrepancies due to differences in sampling points.

\section{Coarse Fraction Analysis}

Table 4 and Figure 4 present the results of the analysis of the coarse fractions ( $>63 \mu \mathrm{m}$ ) separated from the unconsolidated sediments of Site 504 (Holes 501 and 504). The presence of coarse fraction components that occur in concentrations too low to permit distribution curves to be drawn is indicated by symbols only. In addition to the distribution curves of significant components, the ratios of foraminifer fragments to whole for- aminifer tests were plotted versus depth to give some impression of the degree of fragmentation.

Over most of the section, foraminifers and their fragments together with radiolarians form more than $60 \%$ of the coarse fraction. The percentages of benthic foraminifers rarely exceed $5 \%$ and never reach $15 \%$ of the coarse fraction. Within these limits they are somewhat more common between 200 and 230 meters sub-bottom than in other parts of the sequence.

The ratio of fragmentary to whole foraminifer tests shows that the number of whole foraminifers exceeds that of foraminifer fragments only between 120 and 140 meters sub-bottom.

In Subunit Ia the average percentage of total foraminiferal material is about $50 \%$ and therefore higher 
Table 3. $\mathrm{CaCO}_{3}$ content $\mathrm{a}^{\mathrm{a}}$ of the unconsolidated sediments of Hole 504.

\begin{tabular}{|c|c|c|}
\hline $\begin{array}{l}\text { Core/Section } \\
\text { (interval in } \mathrm{cm} \text { ) }\end{array}$ & $\begin{array}{l}\mathrm{CaCO}_{3} \\
\text { Content } \\
\text { (wt.\%) }\end{array}$ & $\begin{array}{c}\text { Average } \mathrm{CaCO}_{3} \\
\text { Content per Core } \\
\text { (wt. \%) }\end{array}$ \\
\hline $1-1,46-47^{b}$ & $0)$ & \\
\hline $1-2,26-27$ & 26 & 33.5 \\
\hline $1-3,46-47$ & 41 & \\
\hline $2-1,46-47$ & 301 & \\
\hline $2-2,46-47$ & 38 & 36.3 \\
\hline $2-3,46-47$ & $39)$ & \\
\hline $3-1,46-47$ & 42 & \\
\hline $3-2,96-97$ & 49 & 46 \\
\hline $3-3,76-77$ & 47J & \\
\hline $4-1,96-97$ & 14) & \\
\hline $4-2,96-97$ & 15 & 27 \\
\hline $4-3,96-97$ & $51)$ & \\
\hline $5-1,96-97$ & $41)$ & \\
\hline $5-2,96-97$ & 30 & 28 \\
\hline $5-3,34-35$ & 13 J & \\
\hline $6-1,96-97$ & $30)$ & \\
\hline $6-2,96-97$ & 51 & 43 \\
\hline $6-3,96-97$ & $48)$ & \\
\hline $7-1,96-97$ & $33)$ & \\
\hline $7-2,105-106$ & $51\}$ & 43 \\
\hline $7-3,96-97$ & $45 J$ & \\
\hline $8-1,96-97$ & 37 ) & \\
\hline $8-2,96-97$ & $46\}$ & 42 \\
\hline $8-3,96-97$ & $43 J$ & \\
\hline $9-1,122-123$ & 39 ) & \\
\hline $9-2,96-97$ & 54 & 39 \\
\hline $9-3,96-97$ & 25 & \\
\hline $10-1,136-137$ & 52 & \\
\hline $10-2,96-97$ & $34\}$ & 40 \\
\hline $10-3,46-47$ & $35)$ & \\
\hline $11-1,46-47$ & $46)$ & \\
\hline $11-2,46-47$ & 61 & 57 \\
\hline $11-3,46-47$ & $63)$ & \\
\hline $12-1,26-27$ & $57)$ & \\
\hline $12-2,46-47$ & $43\}$ & 48 \\
\hline $12-3,46-47$ & $44 J$ & \\
\hline $13-1,46-47$ & $50)$ & \\
\hline $13-2,46-47$ & $40\}$ & 46 \\
\hline $13-3,46-47$ & 49) & \\
\hline $14-1,66-67$ & 8 & \\
\hline $14-2,46-47$ & 18 & 19 \\
\hline $14-3,46-47$ & $30 J$ & \\
\hline $15-1,116-117$ & 91 & \\
\hline $15-2,46-47$ & 63 & 12 \\
\hline $15-3,46-47$ & $22 J$ & \\
\hline $16-1,46-47$ & $28)$ & \\
\hline $16-2,46-47$ & $27\}$ & 25 \\
\hline $16-3,46-47$ & 21) & \\
\hline $17-1,46-47$ & 39 & \\
\hline $17-2,46-47$ & 37 & 35 \\
\hline $17-3,46-47$ & $30 J$ & \\
\hline $18-1,46-47$ & $11)$ & \\
\hline $18-2,46-47$ & 8 & 22 \\
\hline $18-3,46-47$ & $48 J$ & \\
\hline $19-1,139-140$ & $32\}$ & 32 \\
\hline $19-2,46-47$ & $34\}$ & 33 \\
\hline $20-1,46-47$ & $43)$ & \\
\hline $20-2,46-47$ & $53\}$ & 47 \\
\hline $20-3,46-47$ & $46 J$ & \\
\hline $21-1,47-48$ & $59)$ & \\
\hline $21-2,47-48$ & $39\}$ & 49 \\
\hline $21-3,47-48$ & 501 & \\
\hline $22-1,47-48$ & $31\}$ & 33 \\
\hline $22-2,47-48$ & $34\}$ & 33 \\
\hline
\end{tabular}

Table 3. (Continued).

\begin{tabular}{|c|c|c|}
\hline $\begin{array}{l}\text { Core/Section } \\
\text { (interval in cm) }\end{array}$ & $\begin{array}{l}\mathrm{CaCO}_{3} \\
\text { Content } \\
\text { (wt.\%) }\end{array}$ & $\begin{array}{c}\text { Average } \mathrm{CaCO}_{3} \\
\text { Content per Core } \\
\text { (wt. } \% \text { ) }\end{array}$ \\
\hline $23-1,47-48$ & 14 & 14 \\
\hline $24-1,47-48$ & 55 & 51 \\
\hline $24-2,47-48$ & 46 & \\
\hline $25-1,47-48$ & 54 & \\
\hline $25-2,47-48$ & $31\}$ & 46 \\
\hline $25-3,47-48$ & $53)$ & \\
\hline & 44 & 46 \\
\hline $26-3,47-48$ & 45 & \\
\hline $27-1,47-48$ & 33 & \\
\hline $27-2,47-48$ & 36 & 36 \\
\hline $27-3,47-48$ & 39 & \\
\hline $28-1,46-47$ & 38 & 44 \\
\hline $28-2,46-47$ & 50 & \\
\hline $29-1,46-47$ & 47 & \\
\hline $29-2,106-107$ & 50 & 48 \\
\hline $29-3,46-47$ & 46 & \\
\hline $30-1,46-47$ & 52 & \\
\hline $30-2,46-47$ & 49 & 51 \\
\hline $30-3,46-47$ & 52 & \\
\hline $31-1,46-47$ & 67 & 61 \\
\hline $31-2,46-47$ & 55 & \\
\hline $32-1,46-47$ & 68 & \\
\hline $32-2,46-47$ & 64 & 69 \\
\hline $32-3,46-47$ & 751 & \\
\hline $33-1,46-47$ & 66 & 66 \\
\hline $34-1,86-87$ & 50 & 60 \\
\hline $34-2,46-47$ & $69\}$ & \\
\hline $35-1,46-47$ & $55)$ & \\
\hline $35-2,46-47$ & $54\}$ & 57 \\
\hline $35-3,46-47$ & 621 & \\
\hline $36-1,47-48$ & 76 & 72 \\
\hline $36-2,47-48$ & $68\}$ & \\
\hline $37-1,47-48$ & 66 & 69 \\
\hline $37-2,47-48$ & $71\}$ & \\
\hline $38-1,47-48$ & 79 ) & 75 \\
\hline $\begin{array}{l}38-2,47-48 \\
38-3,47-48\end{array}$ & $\left.\begin{array}{l}69 \\
76\end{array}\right\}$ & \\
\hline $40-1,47-48$ & 73 & 71 \\
\hline $40-2,47-48$ & $69\}$ & \\
\hline $41-1,47-48$ & $78)$ & \\
\hline $41-2,44-45$ & 67 & 76 \\
\hline $41-3,47-48$ & $84)$ & \\
\hline $42-1,47-48$ & 88 & 84 \\
\hline $42-2,47-48$ & $80\}$ & 84 \\
\hline $43-1,47-48$ & $74)$ & \\
\hline $43-2,47-48$ & 79 & 77 \\
\hline $43-3,47-48$ & 781 & \\
\hline $44-1,47-48$ & $65\}$ & 74 \\
\hline $44-2,47-48$ & $83\}$ & \\
\hline $45-1,47-48$ & $80\}$ & 78 \\
\hline $45-2,47-48$ & $75\}$ & \\
\hline $46-1,47-48$ & 80 & 80 \\
\hline $47-1,47-48$ & 80 & 80 \\
\hline $48-1,47-48$ & 74 & 74 \\
\hline $49-1,47-48$ & 78 & 78 \\
\hline $50-1,46-47$ & 77 & 77 \\
\hline $51-1,46-47$ & 71 & 71 \\
\hline $52-1,46-47$ & 82 & 82 \\
\hline $53-1,32-33$ & 71 & 71 \\
\hline
\end{tabular}

a "Karbonat Bombe" determinations.

b Ash. 
Table 4. Composition of coarse fraction samples from Holes 501 and 504.

\begin{tabular}{|c|c|c|c|c|c|c|c|c|c|c|c|c|c|c|c|c|}
\hline $\begin{array}{l}\text { Hole/ } \\
\text { Core }\end{array}$ & $\begin{array}{c}\text { Fora- } \\
\text { minifers } \\
\text { (whole } \\
\text { tests) }\end{array}$ & $\begin{array}{l}\text { Fora- } \\
\text { minifer } \\
\text { Frag- } \\
\text { ments }\end{array}$ & $\begin{array}{l}\text { Total } \\
\text { Fora- } \\
\text { miniferal } \\
\text { Material }\end{array}$ & $\begin{array}{l}\text { Foraminifer } \\
\text { Fragments }\end{array}$ & $\begin{array}{l}\text { Radio- } \\
\text { larians }\end{array}$ & Diatoms & $\begin{array}{c}\text { Fish } \\
\text { Debris }\end{array}$ & Pellets & $\begin{array}{l}\text { Echino- } \\
\text { derm } \\
\text { Spicules }\end{array}$ & $\begin{array}{l}\text { Sponge } \\
\text { Spicules }\end{array}$ & $\begin{array}{c}\text { Volcanic } \\
\text { Glass }\end{array}$ & Quartz & Feldspar & Mica & Pyrite & $\begin{array}{c}\text { Miscel- } \\
\text { laneous } \\
\text { Components }\end{array}$ \\
\hline
\end{tabular}

Proportion of Coarse Fraction ${ }^{\text {a }}$ Samples (grain \%)

501

\begin{tabular}{|c|c|c|c|c|c|c|c|c|c|c|c|c|c|c|c|c|}
\hline 1 & 2.8 & 42.6 & 45.4 & 14 & 49.4 & 0.3 & 0.3 & 2.2 & 0 & 0 & $\operatorname{Tr}$ & 0 & $\mathrm{Tr}$ & 0 & $\mathrm{Tr}$ & 1.1 \\
\hline 3 & 11.2 & 35.4 & 46.6 & 3.2 & 43.6 & 4.6 & 0.5 & 1.9 & $\mathrm{Tr}$ & $\mathrm{Tr}$ & $\operatorname{Tr}$ & 0 & 0 & 0 & 1.4 & $\mathrm{Tr}$ \\
\hline 4 & 6.4 & 18.3 & 24.7 & 2.9 & 57.9 & 3.6 & 3.2 & 0.4 & $\mathrm{Tr}$ & 0 & 5 & 0 & 0 & 0 & 4.3 & $\mathrm{Tr}$ \\
\hline 5 & 8.7 & 45 & 53.7 & 5.2 & 38.1 & 0.9 & 3.0 & 1.3 & 0 & 0 & 1.3 & 0 & 0 & $\operatorname{Tr}$ & $\mathrm{Tr}$ & $\mathrm{Tr}$ \\
\hline 6 & 12.5 & 28.1 & 40.6 & 2.3 & 50 & 0.5 & 2.1 & 0.5 & 2.1 & 0 & 1.0 & 0 & 0 & 0 & 2.1 & 1.1 \\
\hline 1 & 22.1 & 35.2 & 57.3 & 1.6 & 29.5 & 0.5 & 0.6 & 2.5 & 0 & 0 & 5.7 & 0 & 0 & 0 & 1.3 & 2.4 \\
\hline 2 & 10 & 37.1 & 47.1 & 3.7 & 42.4 & 0.2 & 0.5 & 2.2 & 0 & 0 & 5.1 & 0 & $\mathrm{Tr}$ & 0 & $\mathrm{Tr}$ & 1.8 \\
\hline 3 & 17.2 & 35.9 & 53.1 & 2.1 & 37.5 & 0.6 & 1.4 & 1.5 & 0 & 0 & 3.7 & 0 & 0 & $\mathrm{Tr}$ & 1.6 & $\mathrm{Tr}$ \\
\hline 4 & 21.7 & 30.3 & 52 & 1.4 & 41.4 & 0.9 & 0.8 & 1.2 & 0 & 0 & 1.3 & 0 & $\mathrm{Tr}$ & $\mathrm{Tr}$ & $\mathrm{Tr}$ & 1.2 \\
\hline 5 & 13.8 & 31.1 & 44.9 & 2.3 & 49.1 & 1.8 & 0.5 & 1.5 & 0 & 0 & 0.8 & 0 & $\mathrm{Tr}$ & $\mathrm{Tr}$ & $\mathrm{Tr}$ & $\mathrm{Tr}$ \\
\hline 6 & 8.3 & 44.9 & 53.2 & 5.4 & 40.3 & 2.2 & 0.3 & 1.2 & 0 & 0 & 1.2 & 0 & 0 & 0 & 1.2 & $\mathrm{Tr}$ \\
\hline 7 & 7.5 & 40.2 & 47.7 & 5.4 & 38.8 & 2.8 & 0.2 & 1.0 & 0 & 0 & 8.3 & 0 & 0 & $\mathrm{Tr}$ & $\operatorname{Tr}$ & $\mathrm{Tr}$ \\
\hline 8 & 10 & 42.1 & 52.1 & 4.2 & 44.8 & 0.4 & 0.7 & - & $\mathrm{Tr}$ & 0 & $\mathrm{Tr}$ & 0 & 0 & $\mathrm{Tr}$ & $\mathrm{Tr}$ & $\mathrm{Tr}$ \\
\hline 9 & 18.1 & 36.3 & 54.4 & 2 & 44.1 & 0.6 & 0.3 & 0.1 & 0 & 0 & $\mathrm{Tr}$ & 0 & 0 & 0 & $\operatorname{Tr}$ & 0 \\
\hline 10 & 13.3 & 43.0 & 56.3 & 3.2 & 37.4 & 2 & 0.7 & 1.2 & $\mathrm{Tr}$ & $\mathrm{Tr}$ & 1.9 & 0 & 0 & $\operatorname{Tr}$ & $\operatorname{Tr}$ & 0 \\
\hline 11 & 16.1 & 38.8 & 54.9 & 2.4 & 40.7 & 1 & 0.7 & 0.2 & 0 & $\mathrm{Tr}$ & 1 & 0 & $\mathrm{Tr}$ & $\mathrm{Tr}$ & 1.0 & $\mathrm{Tr}$ \\
\hline 12 & 7.5 & 38.8 & 46.3 & 5.2 & 46.7 & 0.1 & 1.1 & 1.2 & $\mathrm{Tr}$ & $\mathrm{Tr}$ & 2.3 & 0 & $\mathrm{Tr}$ & 0 & 1.2 & $\mathrm{Tr}$ \\
\hline 13 & 9.6 & 34.8 & 44.4 & 3.6 & 42.5 & 1.6 & 1.1 & 1.4 & 0 & $\mathrm{Tr}$ & 5.6 & 0 & 0 & 0 & 2.3 & $\mathrm{Tr}$ \\
\hline 14 & 6.7 & 36.7 & 43.4 & 5.5 & 43.1 & 5.6 & 1.4 & 3.8 & 0 & $\operatorname{Tr}$ & $\mathrm{Tr}$ & 0 & 0 & 0 & 1.2 & $\mathrm{Tr}$ \\
\hline 15 & 13.3 & 31 & 44.3 & 2.3 & 45.5 & 0.9 & 1.0 & 1.5 & $\mathrm{Tr}$ & $\mathrm{Tr}$ & $\mathrm{Tr}$ & 0 & 0 & 0 & 5.1 & $\mathrm{Tr}$ \\
\hline 16 & 6.4 & 23.7 & 29.5 & 3.7 & 56.8 & 4.3 & 1.5 & 1.9 & 0 & 1.0 & $\mathrm{Tr}$ & 0 & 0 & $\mathrm{Tr}$ & 2.4 & 1.1 \\
\hline 17 & 7.6 & 24.5 & 32.1 & 3.2 & 57.2 & 5 & 0.7 & 2.9 & .0 & $\mathrm{Tr}$ & 0 & 0 & 0 & 0 & $\mathrm{Tr}$ & $\mathrm{Tr}$ \\
\hline 18 & 10.3 & 23.3 & 33.6 & 2.3 & 53.6 & 2.1 & 2 & 2.8 & $\mathrm{Tr}$ & $\mathrm{Tr}$ & 1.3 & 0 & $\mathrm{Tr}$ & 0 & 2.7 & 1.2 \\
\hline 19 & 7.8 & 18.9 & 26.7 & 2.4 & 59.4 & 0.2 & 0.8 & 8.8 & 0 & $\mathrm{Tr}$ & 1.0 & 0 & 0 & 0 & 1 & 1.6 \\
\hline 20 & 11.3 & 24.4 & 35.7 & 2.2 & 56.9 & 1.2 & 1.2 & 2 & 0 & $\mathrm{Tr}$ & 0 & $\mathrm{Tr}$ & 0 & $\mathrm{Tr}$ & 1.2 & 1 \\
\hline 21 & 17 & 25.7 & 42.7 & 1.5 & 46.6 & 1.5 & 0.6 & 0.9 & $\mathrm{Tr}$ & $\mathrm{Tr}$ & 3.1 & $\mathrm{Tr}$ & $\mathrm{Tr}$ & $\mathrm{Tr}$ & 2.4 & 1.1 \\
\hline 22 & 10.8 & 22.2 & 33 & 2.1 & 47.9 & 2.6 & 1 & 3 & 0.2 & $\mathrm{Tr}$ & 6.5 & $\mathrm{Tr}$ & $\mathrm{Tr}$ & 0 & 4.1 & 1.3 \\
\hline 23 & 6.9 & 16 & 22.9 & 2.3 & 58.6 & 6.9 & 0.9 & 3.2 & 0 & $\operatorname{Tr}$ & 1.8 & 0 & 0 & 0 & 3.7 & 1.2 \\
\hline 24 & 4.3 & 13.7 & 18 & 3.2 & 61.0 & 3.9 & 2.2 & 2.0 & 0 & 1.4 & 10.4 & 0 & 0 & 0 & 1.1 & 0 \\
\hline 25 & 8.1 & 17.5 & 25.6 & 2.2 & 56.3 & 3.5 & 2.1 & 4.3 & $\mathrm{Tr}$ & $\mathrm{Tr}$ & 1.3 & 0 & 0 & 0 & 4.7 & 1.5 \\
\hline 26 & 11.6 & 10.1 & 21.7 & 0.9 & 59.7 & 10.7 & 1.7 & 3.5 & 0 & 0 & 1.3 & 0 & 0 & $\mathrm{Tr}$ & $\operatorname{Tr}$ & 1.9 \\
\hline 27 & 7.4 & 14.2 & 21.6 & 1.9 & 56.6 & 5.3 & 2.7 & 5.1 & $\mathrm{Tr}$ & 0 & 4.4 & 0 & 0 & 0 & 3.4 & $\mathrm{Tr}$ \\
\hline 28 & 11.9 & 10.5 & 21.6 & 0.9 & 61.3 & 4.8 & 1.5 & 6.5 & 0 & 0 & 1.7 & 0 & 0 & $\mathrm{Tr}$ & $\operatorname{Tr}$ & 1 \\
\hline 29 & 15.1 & 25.7 & 22.4 & 1.7 & 48.0 & 2.4 & 2.8 & 0.8 & 0 & 0 & $\mathrm{Tr}$ & 0 & 0 & 0 & 4.1 & $\mathrm{Tr}$ \\
\hline 30 & 9.5 & 19.5 & 29 & 2.1 & 56.4 & 8.6 & 1.7 & 0.1 & 0 & 1 & $\mathrm{Tr}$ & 0 & 0 & 0 & 1.5 & 1.2 \\
\hline 31 & 6.8 & 38.1 & 44.9 & 5.6 & 45 & 2.8 & 1.5 & 0.2 & 0 & $\mathrm{Tr}$ & $\mathrm{Tr}$ & 0 & 0 & $\mathrm{Tr}$ & 3.4 & 1 \\
\hline 32 & 7.1 & 25.4 & 32.5 & 3.6 & 61.2 & 0.5 & 0.6 & 2 & $\mathrm{Tr}$ & $\mathrm{Tr}$ & 1.2 & 0 & $\mathrm{Tr}$ & 0 & $\mathrm{Tr}$ & 1.3 \\
\hline 33 & 7.3 & 41.3 & 48.6 & 5.7 & 47.6 & 1.2 & 0.4 & 0 & 0 & 0 & 0 & 0 & 0 & 0 & 1.5 & $\mathrm{Tr}$ \\
\hline 34 & 4.4 & 34 & 38.4 & 7.7 & 45.6 & 8.1 & 0.5 & 1.2 & 0 & 0 & 2.9 & $\mathrm{Tr}$ & 0 & 0 & $\operatorname{Tr}$ & 2.6 \\
\hline 35 & 3.9 & 20.2 & 24.1 & 5.2 & 54.8 & 17.2 & 0.2 & 0 & 0 & $\mathrm{Tr}$ & 0 & 0 & 0 & 0 & 1.9 & 1.2 \\
\hline 36 & 8 & 39.8 & 47.8 & 5 & 44.9 & 2.7 & 1.2 & 0 & 0 & $\mathrm{Tr}$ & 1.6 & 0 & 0 & 0 & 1.3 & $\mathrm{Tr}$ \\
\hline 37 & 13.9 & 32.9 & 46.8 & 2.4 & 44.7 & 0.9 & 2.1 & 0 & 0 & $\mathrm{Tr}$ & 2.7 & 0 & 0 & 0 & 1.7 & 1 \\
\hline 38 & 3.8 & 24.7 & 28.5 & 6.5 & 29.3 & 0.5 & 1.2 & 0 & 0 & 0 & 38.9 & 0 & 0 & $\mathrm{Tr}$ & $\operatorname{Tr}$ & $\mathrm{Tr}$ \\
\hline 39 & 9.4 & 33.8 & 42.3 & 3.6 & 47.6 & 0.6 & 3.1 & 0 & 0 & 0 & 1.8 & 0 & 0 & 0 & 3.1 & $\mathrm{Tr}$ \\
\hline 40 & 4.7 & 12.1 & 16.8 & 2.6 & 56.4 & 11.1 & 0.3 & 0 & 0 & 0 & 13.8 & $\mathrm{Tr}$ & 0 & $\mathrm{Tr}$ & $\mathrm{Tr}$ & $\mathrm{Tr}$ \\
\hline 41 & 5.9 & 26.4 & 32.3 & 4.5 & 52.9 & 3.6 & 1.7 & 0 & 0 & $\mathrm{Tr}$ & 6.1 & 0 & 0 & 0 & 1.1 & 2.2 \\
\hline 42 & 8.3 & 36.2 & 44.5 & 6.1 & 42.6 & 9.9 & 0.9 & 0 & $\mathrm{Tr}$ & $\mathrm{Tr}$ & $\mathrm{Tr}$ & 0 & $\mathrm{Tr}$ & 0 & $\operatorname{Tr}$ & $\mathrm{Tr}$ \\
\hline 43 & 7.7 & 26.4 & 34.1 & 3.4 & 47.3 & 13.4 & 1.2 & 0 & 0 & $\mathrm{Tr}$ & $\mathrm{Tr}$ & $\mathrm{Tr}$ & 0 & 0 & $\operatorname{Tr}$ & 1.5 \\
\hline 44 & 7.5 & 21.6 & 29.1 & 2.9 & 48.7 & 18 & 0.8 & 0 & 0 & $\mathrm{Tr}$ & $\mathrm{Tr}$ & $\mathrm{Tr}$ & 0 & 0 & 1.4 & 1.3 \\
\hline 45 & 4.7 & 21.2 & 25.9 & 4.5 & 35.6 & 7 & 1.2 & 0 & 0 & $\mathrm{Tr}$ & 27 & $\mathrm{Tr}$ & 0 & 0 & 1.1 & 2 \\
\hline 46 & 7.2 & 17.5 & 24.7 & 2.4 & 58.6 & 1.2 & 4.0 & 0 & $\mathrm{Tr}$ & 1.9 & 2.8 & 1.2 & 0 & 0 & 2.4 & 2 \\
\hline 47 & 7.9 & 33.4 & 41.3 & 4.2 & 50 & 5.1 & 1 & 0 & 0 & 0 & $\mathrm{Tr}$ & $\mathrm{Tr}$ & 0 & 0 & 0 & 2 \\
\hline 48 & 4.9 & 19.8 & 24.7 & 4 & 65.1 & 4.3 & 1 & 0 & 2 & 1 & 0 & $\mathrm{Tr}$ & 0 & 0 & 0 & 1.6 \\
\hline 49 & 14.1 & 28.6 & 42.7 & 2 & 47.6 & 4.5 & 2.3 & 0 & 1 & 1 & 0 & $\mathrm{Tr}$ & 0 & 0 & 0 & $\mathrm{Tr}$ \\
\hline 50 & 2 & 15.3 & 17.3 & 7.7 & 75.6 & 2 & 1 & 0 & 1 & 1 & 0 & 0 & 0 & 0 & 0 & 2.1 \\
\hline 51 & 15.7 & 26.8 & 42.5 & 1.7 & 49.9 & 0.9 & 1.8 & 0 & 0 & 0 & 0 & $\mathrm{Tr}$ & 0 & 0 & 1.8 & 2.2 \\
\hline 52 & 3.6 & 36.6 & 40.2 & 10.2 & 40.7 & 10.3 & 1.5 & 0 & 3 & 0 & 0 & 2 & 0 & 0 & 1 & 1.3 \\
\hline
\end{tabular}

a $>63 \mu \mathrm{m}$.

than that of radiolarians $(40 \%)$. For most parts of the Subunits Ib and Ic it is considerably lower than that of radiolarians. Only at the top of Subunit $\mathrm{Ib}$ and at the boundary between Subunits Ib and Ic is it close to the radiolarian percentages. In Lithologic Unit II the radiolarian percentages continue to exceed the total foraminifer percentages, but generally by a smaller amount than in Subunits Ib and Ic.

Diatoms occur between trace amounts and $18 \%$. Fluctuations in the diatom percentages are considerable, and they become more frequent below Subunit Ia. Phosphatic fragments of fish teeth, here called fish debris, never exceed $4 \%$. Pellets range between trace abun- dances and $9 \%$ and are most abundant in Subunits $\mathrm{Ib}$ and Ic. Other biogenic components occur in very small amounts (below 2\%). Within this fraction sponge spicules are more common than echinoderm spicules (Fig. 4). Chitinous copepod fragments occur only in the uppermost sediments of Hole 501. Ostracods were found at 23.50 meters and between 180 and 200 meters.

Colorless silicic volcanic glass is the only significant land-derived component in the coarse fraction. It occurs from the top of the unconsolidated sequence to a depth of 215 meters sub-bottom. The glass particles are angular and fresh. Fibrous glass particles as well as particles with (fluid-filled?) bubbles are common. Sometimes the 
glass particles are speckled with an opaque mineral, probably authigenic pyrite.

Quartz, plagioclase, and biotite (which is listed as mica) occur in trace amounts within the terrigenous mineral association of the coarse fraction. In Lithologic Unit I feldspar is more common than quartz; in Lithologic Unit II the reverse is true.

Authigenic pyrite also occurs in the coarse fraction. It occurs as spheroids and framboids, mainly in the form of burrow or microfossil coatings or as single spheroids composed of octahedra and cubes. Within the coarse fraction the pyrite percentages range between trace amounts and $5 \%$. The mineral is more common in Subunits Ib and Ic.

In summary, the composition of the coarse fraction varies considerably, as does the bulk composition. Fluctuations are more pronounced between the top of the sediment sequence and 90 meters sub-bottom than in the sediments below that depth.

\section{SEDIMENT CHEMISTRY AND ASH COMPOSITION OF SITES 504 AND 505}

The major oxide composition of 4 ash beds and 34 sediment samples from Holes 504 and 505 are presented in Table 5. All except one sediment sample and one of the ash beds are from Hole 504. We also obtained the trace element content of 27 of the Hole 504 sediment samples (Table 6). We studied Hole 504 in particular detail to determine the variation through time in sediment bulk composition and to see whether hydrothermal activity at the Galapagos Spreading Center had contributed a metalliferous component to the sediments. Most of the samples were from relatively dark, clay-rich beds within the lithologic units and were therefore somewhat less calcareous than the lighter-colored beds nearby.

The ash beds and the six sediment samples for which we do not have trace element data were analyzed for major oxides on board the Glomar Challenger during Leg 69 by J. Etoubleau. $\mathrm{Na}_{2} \mathrm{O}$ was not determined.

Sites 501, 504, and 505 are near three potential sources of airborne volcanic ash. The two most important of these are the highly active magmatic arc volcanoes of the northern Andes and southern Central America, which have episodically produced large volumes of andesitic to rhyolitic tephra (McBirney and Williams, 1964; Zeil, 1979). The nearness of the Andean volcanoes, which are almost directly to the east, makes them more likely sources for ash than the Central American volcanoes. Silicic volcanism has also occurred on several of the $\mathrm{Ga}$ lapagos Islands (McBirney and Williams, 1969), but it has been in the form of lava flows rather than of ash or ignimbrites. This and the unfavorable southwesterly wind direction make the Galapagos Islands unlikely to be the source of ash found near the Costa Rica Rift.

Ash deposits near the surface of sediments in the Panama Basin have been both recovered by coring and dredging and traced acoustically for long distances (Worzel, 1959). One prominent near-surface reflection has been ascribed to the "Worzel Ash", a layer about $10 \mathrm{~cm}$ thick that lies off Central and South America. The geographic extent of the bed was originally thought to be the result of an "exceptional catastrophe" (Menard, 1964, paraphrasing Ewing et al., 1959), but the layer is now thought to be a composite of ash from both Central and South America. More recent coring has uncovered evidence that more than one ash layer contributes to the "Worzel Ash". The most widespread of these is the "L" ash layer of Ninkovich and Shackleton (1975), which occurs within the upper 15 meters of the sediment column in the northern Panama Basin and has its source in South America.

In Hole 504, where the hydraulic piston corer was used, we expected to recover numerous volcanic ash layers in the cores, allowing us to document silicic volcanism on nearby magmatic arcs from the late Miocene to the present. However, despite the high recovery of undisturbed core material and the ubiquitous occurrence of dispersed volcanic glass in the sediments, few ash layers undisturbed by burrowing organisms were encountered. Our analyses of four of these layers are listed in the first four rows of Table 5. The sample from Hole 505 is from an unusually thick ash bed that lies about 16.5 meters below the seafloor and required circulation to punch through with the drill string. It could well be Ninkovich and Shackleton's " $L$ " ash layer.

Smear slide observations of the ash samples analyzed indicate very little glass alteration and up to $20 \%$ combined quartz, feldspars, and heavy minerals, mainly hornblende and biotite. Such concentrations of minerals can result from the aerodynamic sorting within the stratosphere of particles of ash of different density (Carey and Sigurdsson, 1980). These minerals are also present in dispersed amounts throughout the sediments.

The ash analyses show high loss on ignition, reflecting mostly combined water $\left(\mathrm{H}_{2} \mathrm{O}^{+}\right)$, possibly $\mathrm{CO}_{2}$, and slight alteration and oxidation. The high content of $\mathrm{Fe}_{2} \mathrm{O}_{3}$ in the Pliocene sample from Hole 504 (Sample 504-41-1 (136-137 cm)) is the result of pyritization.

The analyses of all the ash samples are similar and highly silicic. Estimates of normative composition, based on the assumption that $\mathrm{Na}_{2} \mathrm{O}$ abundance equals the difference between the total of the analysis and $100 \%$, indicate that all four would plot near the ternary minimum in the system $\mathrm{Qz}-\mathrm{Or}-\mathrm{Ab}$, within or near the field for analyzed granites (Tuttle and Bowen, 1958). Details of the petrology of the samples await more complete study.

Several characteristics of the ash are of importance to the interpretation of sediment pore-fluid composition, however. They include the low $\mathrm{CaO}$ content of the ash, the generally small fraction of ash in the sediments other than the ash beds, and the apparent weak reactivity of the glass in the ash to the action of pore fluids. The lack of reactivity is evidenced by the fresh appearance of glass in smear slides throughout the sediment column of Hole 504 right to the top of the cherts. Evidently no extensive exchange of $\mathrm{Ca}^{2+}$ in the glass with $\mathrm{Mg}^{2+}$ in the sediment pore fluids has occurred, and the strong gradients of these cations in the pore fluids at Site 504 reflect reactions in the underlying basalts (Mottl, Lawrence, et al., this volume).

The chemical composition of the sediment in Holes 504 and 505 (the remainder of Table 5) was evaluated by 


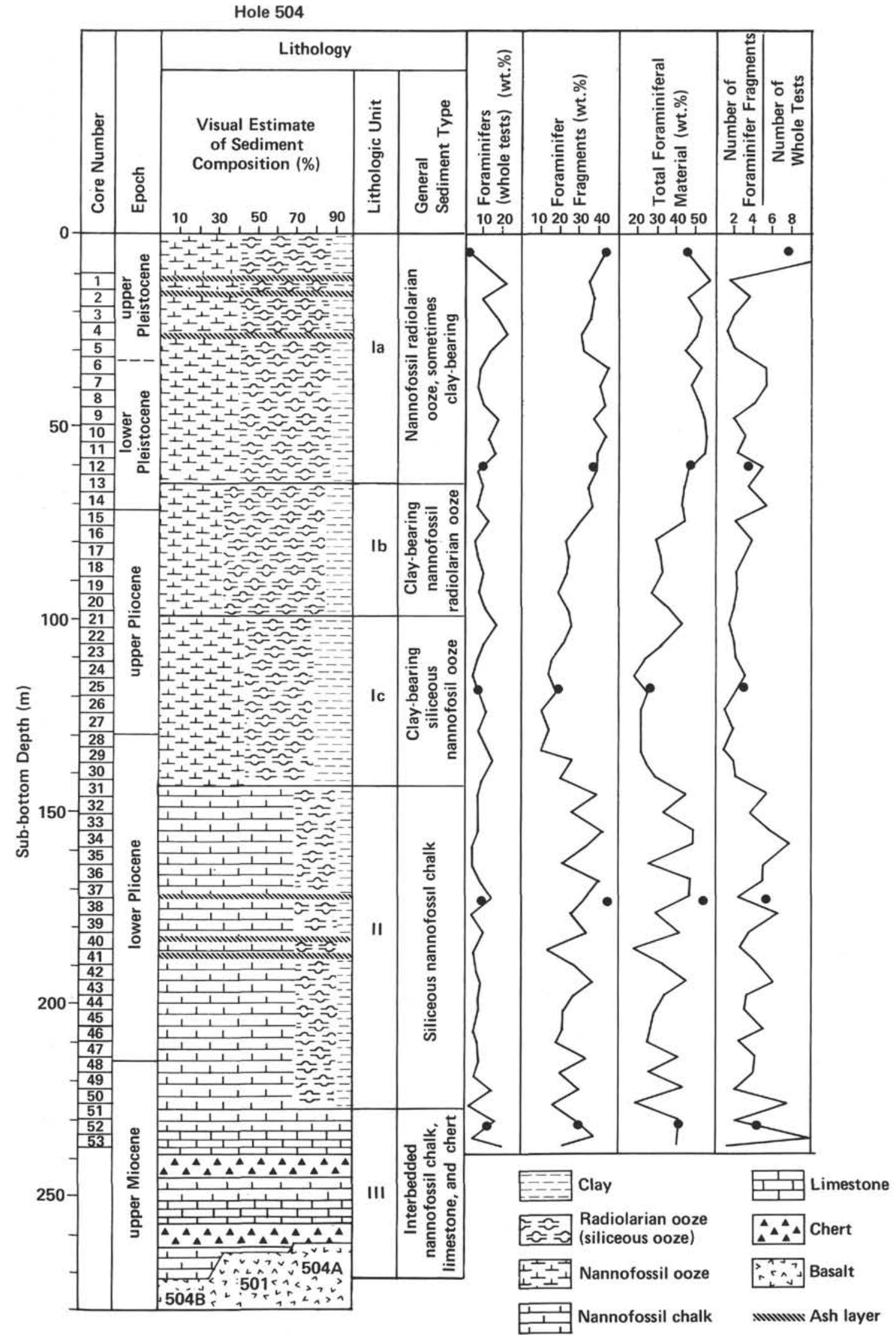

Figure 4. Coarse fraction data for the unconsolidated sediments of Hole 504. 


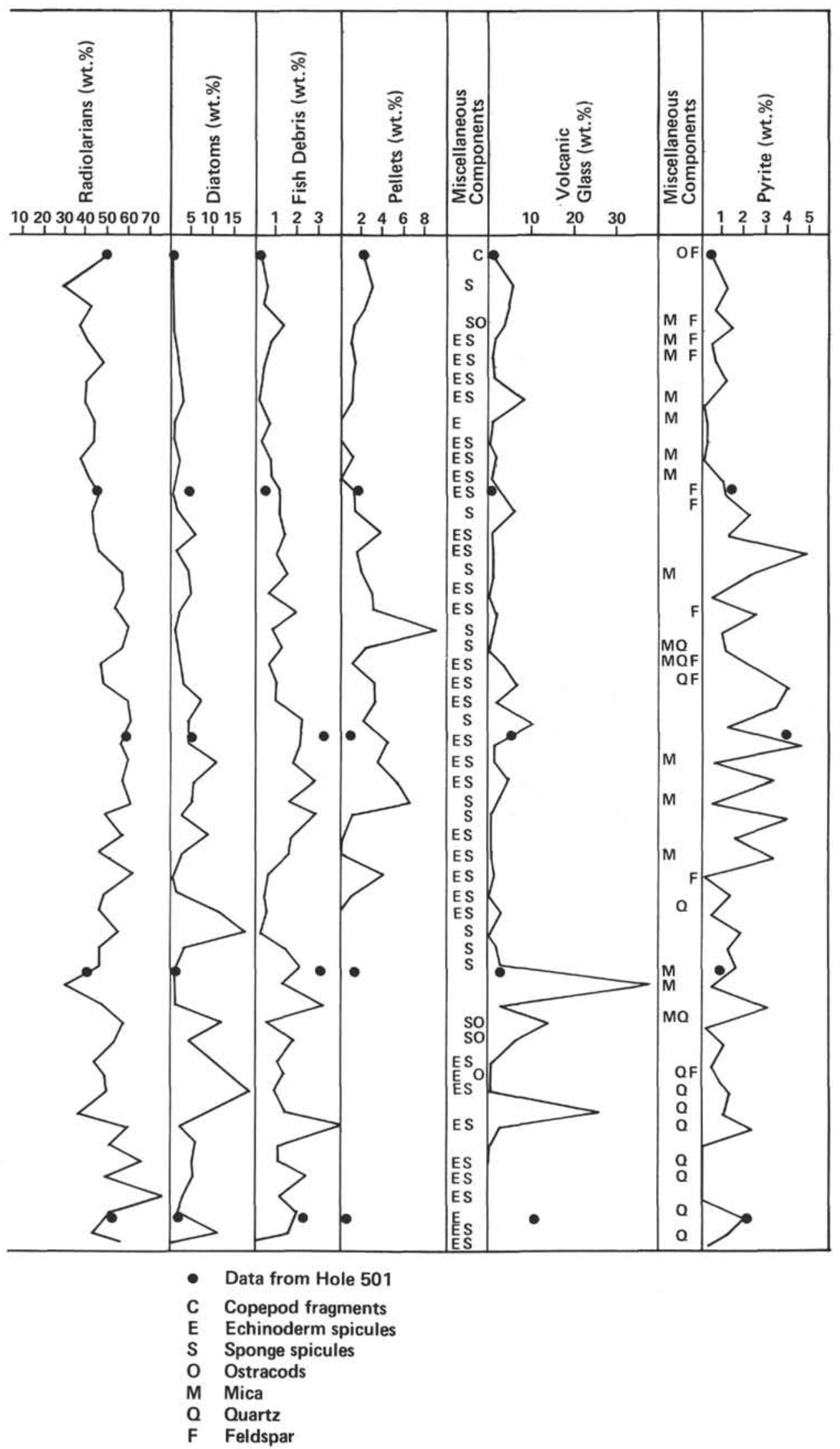

Figure 4. (Continued). 
Table 5. Chemical composition of ashes and sediments in Holes 504 and 505.

\begin{tabular}{|c|c|c|c|c|c|c|c|c|c|c|c|c|c|c|c|c|c|c|c|c|}
\hline \multirow{3}{*}{$\begin{array}{l}\text { Lithologic } \\
\text { Unit }\end{array}$} & \multirow{3}{*}{$\begin{array}{c}\text { Sample } \\
\text { (interval in } \mathrm{cm} \text { ) }\end{array}$} & \multirow{3}{*}{$\begin{array}{l}\text { Sub-bottom } \\
\text { Depth (m) }\end{array}$} & \multirow{2}{*}{\multicolumn{13}{|c|}{ Major Oxides $\left(w . w_{0}\right)^{\mathrm{a}}$}} & \multicolumn{5}{|c|}{ Principal Components } \\
\hline & & & & & & & & & & & & & & & & $\begin{array}{l}\text { Pelagic } \\
\text { Clay }\end{array}$ & $\begin{array}{l}\text { Biogenic } \\
\mathrm{CaCO}_{3}\end{array}$ & $\begin{array}{l}\text { Biogenic } \\
\mathrm{SiO}_{2}\end{array}$ & $\begin{array}{l}\text { Hydrog- } \\
\text { enous }\end{array}$ & $\begin{array}{l}\text { Metal- } \\
\text { liferous }\end{array}$ \\
\hline & & & $\mathrm{SiO}_{2}$ & $\mathrm{TiO}_{2}$ & $\mathrm{Al}_{2} \mathrm{O}_{3}$ & $\mathrm{Fe}_{2} \mathrm{O}_{3}$ & $\mathrm{MnO}$ & $\mathrm{MgO}$ & $\mathrm{CaO}$ & $\mathrm{Na}_{2} \mathrm{O}$ & $\mathrm{K}_{2} \mathrm{O}$ & $\mathrm{P}_{2} \mathrm{O}_{5}$ & $\mathrm{SO}_{3}$ & L.O.I. & Sum & & Proport & on of Sedin & nent $(\%)$ & \\
\hline \multirow[t]{4}{*}{ Ash } & $504-1-2,74-75$ & & 73.18 & 0.30 & & 1.88 & 0.06 & 0.53 & & - & 4.09 & 0.09 & - & $5.68^{b}$ & 96.16 & & & & & \\
\hline & 01.58 & $\begin{array}{l}13.24 \\
14.98\end{array}$ & $\begin{array}{l}73.18 \\
73.39\end{array}$ & 0.26 & $\begin{array}{l}14,30 \\
14.02\end{array}$ & $\begin{array}{l}1.80 \\
1.62\end{array}$ & 0.08 & 0.50 & 1.29 & $\overline{-}+x+x+$ & 4.33 & 0.04 & $=$ & $8.24^{\mathrm{b}}$ & 95.53 & & & & & \\
\hline & $41-1,136-137$ & 187.86 & 73.08 & 0.25 & 13.22 & 4.01 & 0.12 & 0.47 & 1.31 & $=$ & 4.18 & 0.08 & - & $7.80^{\mathrm{b}}$ & 96.72 & & & & & \\
\hline & $505-3-5,57-60$ & 16.5 & 71.88 & 0.30 & 14.27 & 1.96 & 0.08 & 0.80 & 2.20 & $=$ & 4.41 & 0.06 & - & $9.04^{b}$ & 95.96 & & & & & \\
\hline \multirow[t]{7}{*}{ la } & $504-1-1,5-8$ & 10.05 & 39.14 & 0.30 & 7.96 & 3.50 & 0.33 & 2.33 & 17.56 & 2.49 & 1.02 & 0.11 & 0.79 & 24.10 & 99.63 & 53.29 & 31.23 & 14.21 & 1.14 & 0.11 \\
\hline & $2-2,100-102$ & 16.42 & 29.21 & 0.22 & 5.86 & 2.97 & 0.23 & 1.75 & 25.70 & 3.08 & 0.82 & 0.13 & 1.07 & 27.90 & 98.94 & 40.31 & 46.97 & 11.20 & 0.82 & 0.65 \\
\hline & 2. $51-54$ & 25.21 & 35.92 & 0.26 & $\begin{array}{l}6.35 \\
6.35\end{array}$ & 3.37 & 0.38 & 2.30 & 19.00 & 3.19 & 0.97 & 0.13 & 1.31 & 25.10 & 98.78 & 47.66 & 35.12 & 15.29 & 1.37 & 0.54 \\
\hline & 2,52 & 34.02 & 34.14 & 0.20 & 5.32 & 2.73 & 0.39 & 1.77 & 25.61 & 1.01 & 0.63 & 0.13 & 1.03 & 26.60 & 99.56 & 35.12 & 44.91 & 18.06 & 1.33 & 0.58 \\
\hline & & & 32.21 & 0.20 & 5.05 & 2.33 & 0.33 & 1.53 & 26.19 & 1.54 & 0.44 & 0.11 & 0.98 & 28.10 & 99.01 & & 47.06 & 17.34 & 1.15 & \\
\hline & $10-2,52-55$ & 51.62 & 40.80 & 0.33 & 8.19 & 3.53 & 0.20 & 2.13 & 15.67 & 3.44 & 1.26 & 0.12 & 1.61 & & 99.58 & & 28.24 & & & \\
\hline & & 53.12 & 41.24 & & 7.53 & 3.31 & 0.22 & 1.87 & 18.36 & & & & 1.37 & 22.50 & 99.48 & 49.3 & 31.5 & 7.73 & & 0.16 \\
\hline \multirow[t]{10}{*}{ Ib } & $4-14-1,5$ & 67.70 & 47.19 & $0.3 \mathrm{C}$ & 7.66 & 4.66 & & 2.32 & 8.03 & 2.75 & 1.3 & 0.16 & 3.72 & 20.80 & 99.22 & 55.47 & 15.45 & 26.18 & & 1.67 \\
\hline & & 72.28 & 68.91 & 0.36 & 7.61 & 4.87 & & 2.90 & 10.11 & - & 1.11 & 0.20 & - & $17.49^{b}$ & $96.34^{b}$ & 42.34 & 14.94 & 40.20 & 0.95 & 1.58 \\
\hline & & 72.45 & & 0.36 & 9.17 & 6.55 & 0.38 & 3.35 & 7.13 & - & 1.26 & 0.21 & - & $20.54^{b}$ & $98.51^{\mathrm{b}}$ & 50.14 & 10.36 & 35.94 & & 2.49 \\
\hline & $16-1,10$ & 77.05 & 60.17 & 0.30 & 8.07 & 3.95 & 0.64 & 2.44 & 20.47 & 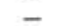 & 0.99 & 0.26 & - & $28.30^{\mathrm{b}}$ & $97.29^{\mathrm{b}}$ & 41.48 & 27.95 & & 1.70 & 0.44 \\
\hline & $16-2,34$ & 77.84 & 44.16 & 0.20 & 5.25 & 2.80 & 0.36 & 1.64 & 16.16 & 2.20 & 0.93 & 0.14 & 1.88 & 23.40 & 99.11 & 36.18 & 30.10 & & & is \\
\hline & $17-2,12$ & 82.92 & 59.23 & 0.34 & 9.24 & 4.98 & 1.15 & 2.37 & 18.14 & - & 0.60 & 0.23 & - & $30.31^{\mathrm{b}}$ & $96.28^{b}$ & 47. & 24. & & & \\
\hline & & 83.74 & 65.82 & 0.19 & 5.19 & 2.70 & 0.48 & 66 & 21.05 & - & 0.56 & 0.24 & - & 32.05 & & & & & & \\
\hline & & 84.04 & & 0.27 & 6.97 & 3.90 & 0.3 & & 11.08 & 2.34 & 1.16 & 0.16 & 4.27 & 23.60 & 98.80 & & & & & \\
\hline & & & 70.50 & 0.20 & 5.10 & 2.47 & 0.21 & 1.46 & 18.10 & & 0.65 & 0.18 & & & & & & & & \\
\hline & $19-1,50-53$ & 89.70 & 52.07 & 0.19 & 4.45 & 2.46 & 0.15 & 1.04 & 12.20 & & 0.87 & 0.12 & 2.71 & & & & & & & \\
\hline \multirow[t]{5}{*}{ Ic } & $504-21-3,115-120$ & & 38.74 & 0.18 & 4.76 & 3.17 & 0.17 & 1.14 & 22.11 & 1.07 & & & 2.64 & & & & & & & \\
\hline & $\begin{array}{l}23-1,36 \\
25-2,95\end{array}$ & 107. & $\begin{array}{l}50.13 \\
41.67\end{array}$ & $\begin{array}{l}0.20 \\
0.12\end{array}$ & $\begin{array}{l}5.25 \\
3.64\end{array}$ & $\begin{array}{l}2.51 \\
1.61\end{array}$ & 0.14 & $\begin{array}{l}1.28 \\
0.80\end{array}$ & 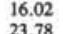 & 1.16 & 0.72 & 0.11 & 1.21 & $\begin{array}{l}20.70 \\
24.80\end{array}$ & $\begin{array}{l}99.44 \\
99.66\end{array}$ & 34. & ${ }_{42 .}^{28 .}(-1)$ & $\begin{array}{l}35.93 \\
32.58\end{array}$ & & $\begin{array}{l}0.47 \\
0.25\end{array}$ \\
\hline & & & & $\begin{array}{l}0.12 \\
0.27\end{array}$ & 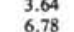 & $\begin{array}{l}1.61 \\
3.25\end{array}$ & $\begin{array}{l}0.26 \\
0.09\end{array}$ & 53 & $\begin{array}{r}23.78 \\
7.34\end{array}$ & $\begin{array}{l}1.25 \\
1.24\end{array}$ & ${ }_{0.8}^{0.6}-3-1$ & $\begin{array}{l}0.13 \\
0.14\end{array}-1$ & $\begin{array}{l}0.99 \\
1.47\end{array}$ & $\begin{array}{l}24.80 \\
14.80\end{array}$ & 62 & & $\begin{array}{l}42 . \\
12 .\end{array}$ & & & $\begin{array}{l}0.25 \\
0.51\end{array}$ \\
\hline & & & & 0.2 & & 2.76 & & & $\begin{array}{r}7.34 \\
20.92\end{array}$ & 1.23 & & $\begin{array}{l}0.14 \\
0.17\end{array}$ & & & & & & & & \\
\hline & & & & 0.22 & & 2. & & 1.34 & 21.7 & 1.31 & & 0. & & & & & & & & \\
\hline \multirow[t]{9}{*}{ II } & 504-34- & & & 0.3 & 8. & 3. & & & 13. & 1.22 & & 0 . & & & & & & & & 0.1. \\
\hline & & & & 0. & 5. & & & & & & & & & & & & & & & \\
\hline & & & & & & & & & & & & & & & 98.55 & & & & & \\
\hline & & & & & & & & & & & & & & & & & & & & 0.45 \\
\hline & 41 & & 21.22 & 0.13 & 2.59 & 1.20 & & 75 & 38 & & 0 & 0. & 0.59 & 33. & & 17. & & & & 0.37 \\
\hline & & & & 0.05 & 1.32 & 0.96 & 0. & 42 & $44.6-610$ & & 0.1 & 0.120 & 0.84 & 36. & & & & & & 4 \\
\hline & & & & 0.0 & 2. & & 0. & 0. & 38. & & & 0.1 & & & & & & & & 0. \\
\hline & & & & 0.1 & 2. & & & & & & & & & & & & & & & \\
\hline & & & & 0. & & 0.7 & & & 43. & $0.1 \quad r$ & & 0. & 0.52 & & & & & & & \\
\hline III & $4-53-1,64-67$ & 235.64 & 41.82 & 0.02 & 0.86 & 0.55 & 0.08 & 0.37 & 27.18 & 0.46 & 0.17 & 0.07 & 0.51 & 26.90 & & 5. & & & & 0.55 \\
\hline 1 & $5-1-1,0-3$ & 0.01 & 54.85 & 0.41 & 11.32 & 5.84 & 1.89 & 2.89 & 17.53 & - & 1.25 & 0.25 & - & $22.18^{\mathrm{b}}$ & $96.23^{\mathrm{b}}$ & 56.74 & 23.34 & 14.47 & 5.90 & 0.71 \\
\hline
\end{tabular}

a All analyses by XRF. Samples analyzed by V. Marchig, H. Rascha, and J. Lodziak except those indicated by Note b. Precision is $2-3 \%$ of the amount present. Samples were sieved through $63 \mu$ mesh before analysis to remove any rust contaminants from the drill pipe. This may have affected $\mathrm{SiO}_{2}$ and $\mathrm{CaCO}_{3}$ abundances slightly.
$\mathrm{J}$. Etoubleau, analyst. Sums do not include L.O.I. (loss on ignition). All other analyses include L.O.I. in sum.

Table 6. Trace element abundances (ppm) in Hole 504 sediments. ${ }^{a}$

\begin{tabular}{|c|c|c|c|c|c|c|c|c|c|c|c|c|c|c|c|c|c|c|c|c|c|c|c|c|}
\hline $\begin{array}{l}\text { Lithologic } \\
\text { Unit }\end{array}$ & $\begin{array}{l}\text { Core/Section } \\
\text { (interval in } \mathrm{cm} \text { ) }\end{array}$ & $\mathrm{Bi}$ & $\mathrm{Cu}$ & $\mathrm{Co}$ & Mo & $\mathrm{Nb}$ & $\mathrm{Ni}$ & $\mathrm{Pb}$ & $\mathrm{Rb}$ & $\mathrm{Sn}$ & $\mathrm{Sr}$ & $\mathrm{Ta}$ & Th & $\mathrm{U}$ & W & $\mathrm{Y}$ & $\mathrm{Zn}$ & $\mathrm{Zr}$ & $\mathrm{Ba}$ & $\mathrm{Ce}$ & $\mathrm{Cr}$ & La & $\mathrm{Sc}$ & v \\
\hline \multirow[t]{7}{*}{ Ia } & $1-1,5-8$ & $<6$ & 132 & 23 & 4 & 4 & 137 & $<5$ & 27 & 40 & 768 & $<5$ & $<5$ & 10 & $<5$ & 17 & 248 & 63 & 2744 & 6 & 52 & 55 & 17 & 137 \\
\hline & $2-2,100-102$ & 6 & 122 & 18 & 4 & 5 & 127 & $<5$ & 17 & 33 & 1114 & $<5$ & $<5$ & 9 & $<5$ & 16 & 208 & 54 & 2845 & 1 & 43 & 9 & 7 & 107 \\
\hline & $4-2,51-54$ & $<6$ & 133 & 25 & 6 & $<3$ & 191 & $<5$ & 23 & 23 & 863 & 6 & $<5$ & 6 & 8 & 18 & 305 & 54 & 3088 & 0 & 41 & 16 & 12 & 164 \\
\hline & $6-2,52-55$ & $<6$ & 318 & 17 & $<3$ & $<3$ & 151 & 5 & 19 & 32 & 1073 & $<5$ & $<5$ & 6 & $<5$ & 16 & 261 & 41 & 2945 & 2 & 38 & 22 & 6 & 128 \\
\hline & $8-2,43-47$ & $<6$ & 155 & 15 & $<3$ & $<3$ & 124 & $<5$ & 12 & 29 & 1011 & $<5$ & $<5$ & 7 & $<5$ & 11 & 204 & 39 & 2391 & 6 & 42 & 22 & 9 & 104 \\
\hline & $10-2,52-55$ & $<6$ & 170 & 28 & $<3$ & $<3$ & 162 & $<5$ & 29 & $<20$ & 770 & $<5$ & $<5$ & 5 & $<5$ & 22 & 204 & 61 & 3269 & 0 & 47 & 19 & 17 & 144 \\
\hline & $10-3,52-53$ & $<6$ & 207 & 25 & $<3$ & $<3$ & 160 & 6 & 29 & 21 & 839 & $<5$ & $<5$ & 8 & 7 & 24 & 312 & 63 & 3554 & 0 & 50 & 23 & 16 & 148 \\
\hline \multirow[t]{4}{*}{$\mathrm{Ib}$} & $14-1,50-53$ & $<6$ & 353 & 25 & 31 & $<3$ & 303 & 8 & 37 & 26 & 601 & $<5$ & $<5$ & 13 & $<5$ & 31 & 303 & 82 & 5958 & 0 & 61 & 28 & 19 & 252 \\
\hline & $16-2,34-37$ & $<6$ & 205 & 21 & 15 & $<3$ & 124 & $<5$ & 25 & 122 & 836 & $<5$ & $<5$ & 18 & $<5$ & 22 & 206 & 49 & 4892 & 0 & 50 & 18 & 13 & 133 \\
\hline & $17-3,64-67$ & $<6$ & 455 & 36 & 65 & $<3$ & 327 & $<5$ & 33 & 114 & 792 & $<5$ & $<5$ & 20 & $<5$ & 32 & 432 & 91 & 6889 & 0 & 63 & 34 & 20 & 277 \\
\hline & $19-1,50-53$ & $<6$ & 200 & 19 & 13 & $<3$ & 138 & $<5$ & 24 & $<20$ & 710 & $<5$ & $<5$ & 12 & $<5$ & 20 & 209 & 53 & 4009 & 0 & 40 & 17 & 11 & 164 \\
\hline \multirow[t]{6}{*}{ Ic } & $21-3,105-110$ & $<6$ & 213 & 23 & 4 & 4 & 194 & $<5$ & 21 & $<20$ & 967 & $<5$ & $<5$ & 5 & $<5$ & 20 & 281 & 55 & 3628 & 0 & 43 & 18 & 7 & 133 \\
\hline & $23-1,36-39$ & $<6$ & 176 & 19 & $<3$ & $<3$ & 100 & 10 & 21 & 48 & 781 & $<5$ & $<5$ & 4 & $<5$ & 19 & 241 & 50 & 4066 & 0 & 40 & 17 & 15 & 116 \\
\hline & $25-2,95-97$ & $<6$ & 97 & 9 & $<3$ & $<3$ & 85 & $<5$ & 19 & $<20$ & 1061 & $<5$ & $<5$ & 5 & $<5$ & 16 & 171 & 36 & 3212 & 0 & 24 & 16 & 8 & 82 \\
\hline & $27-2,15-18$ & $<6$ & 193 & 23 & 3 & $<3$ & 133 & 17 & 28 & 44 & 568 & $<5$ & $<5$ & 10 & $<5$ & 20 & 283 & 57 & 4519 & 0 & 46 & 16 & 16 & 144 \\
\hline & $30-1,7-10$ & $<6$ & 174 & 21 & 6 & 3 & 128 & 11 & 22 & 27 & 989 & $<5$ & $<5$ & 4 & 5 & 29 & 235 & 55 & 4815 & 0 & 38 & 26 & 11 & 112 \\
\hline & $31-2,20-23$ & $<6$ & 195 & 26 & $<3$ & 4 & 119 & 12 & 25 & 29 & 971 & $<5$ & $<5$ & 3 & $<5$ & 23 & 207 & 53 & 3242 & 0 & 37 & 26 & 14 & 105 \\
\hline \multirow[t]{9}{*}{ II } & $34-1,75-78$ & $<6$ & 323 & 35 & $<3$ & $<3$ & 208 & 16 & 36 & 29 & 737 & $<5$ & $<5$ & 8 & 6 & 31 & 353 & 73 & 5135 & 0 & 49 & 29 & 19 & 206 \\
\hline & $35-3,6-9$ & $<6$ & 263 & 22 & $<3$ & $<3$ & 154 & 11 & 23 & $<20$ & 948 & 5 & $<5$ & 3 & $<5$ & 28 & 258 & 49 & 4478 & 0 & 39 & 23 & 15 & 117 \\
\hline & $37-2,17-20$ & $<6$ & 171 & 20 & $<3$ & $<3$ & 125 & 7 & 16 & $<20$ & 1216 & $<5$ & $<5$ & $<3$ & $<5$ & 23 & 155 & 47 & 3354 & 0 & 35 & 26 & 6 & 77 \\
\hline & $39-1,22-25$ & $<6$ & 131 & 10 & $<3$ & $<3$ & 82 & $<5$ & 8 & 48 & 1313 & $<5$ & $<5$ & $<3$ & $<5$ & 17 & 106 & 24 & 2142 & 0 & 24 & 19 & 0 & 48 \\
\hline & $41-2,34-37$ & $<6$ & 107 & 16 & $<3$ & $<3$ & 92 & $<5$ & 7 & 25 & 1340 & $<5$ & $<5$ & $<3$ & $<5$ & 18 & 140 & 28 & 2576 & 0 & 20 & 26 & 0 & 69 \\
\hline & $43-2,51-54$ & $<6$ & 66 & 6 & $<3$ & $<3$ & 52 & $<5$ & 5 & $<20$ & 1241 & $<5$ & $<5$ & $<3$ & $<5$ & 10 & 50 & 16 & 1819 & 11 & 20 & 19 & 0 & 25 \\
\hline & $45-1,33-36$ & $<6$ & 101 & 9 & $<3$ & $<3$ & 50 & $<5$ & 15 & $<20$ & 1179 & $<5$ & 7 & $<3$ & $<5$ & 8 & 54 & 38 & 1510 & 6 & 18 & 32 & 0 & 28 \\
\hline & $47-1,133-136$ & $<6$ & 221 & 12 & $<3$ & $<3$ & 101 & $<5$ & 11 & 52 & 1137 & $<5$ & $<5$ & $<3$ & $<5$ & 23 & 179 & 31 & 4635 & 0 & 26 & 35 & 8 & 78 \\
\hline & $50-1,31-34$ & $<6$ & 58 & 5 & $<3$ & $<3$ & 39 & $<5$ & 3 & $<20$ & 1274 & $<5$ & $<5$ & $<3$ & $<5$ & 12 & 67 & 15 & 1836 & 7 & 11 & 24 & 0 & 32 \\
\hline III & $53-1,64-67$ & $<6$ & 66 & 5 & $<3$ & $<3$ & 47 & $<5$ & 4 & $<20$ & 857 & $<5$ & $<5$ & 4 & $<5$ & 11 & 39 & 14 & 1890 & 0 & 12 & 16 & 2 & 23 \\
\hline
\end{tabular}

${ }^{a}$ Determined by XRF. Analysts were V. Marchig, H. Rascha, and J. Lodziak. Precision is $25 \%$ at detection limits.

using the procedure of Bischoff, Heath, et al. (1979). The sediments can be considered to be a combination of several simple components: (1) a "detrital" component with the composition of pelagic clay; (2) biogenic calcareous material; (3) biogenic siliceous material; (4) hydrogenous (mainly Mn) metals; and (5) metalliferous sediment (the hydrothermal component). The calculation is performed like that of a norm. The pelagic clay is taken to be the average Pacific pelagic clay listed in

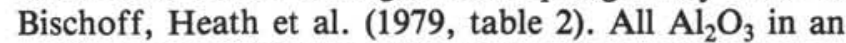
analysis is assumed to reside in the pelagic clay component. The calcareous component is assumed to be pure 
$\mathrm{CaCO}_{3}$, and the siliceous biogenic component is assumed to be pure $\mathrm{SiO}_{2}$. $\mathrm{MnO}$ occurs in both the hydrogenous and metalliferous fractions, but the ratio of $\mathrm{Ni}$ (ppm) to $\mathrm{MnO}(\%)$ is assumed to be $360: 1$ in the hydrogenous fraction, its nominal value in eastern Pacific manganese nodules (Bischoff, Piper, et al., 1979). In the case of our samples, only four have $\mathrm{MnO}$ in very slight excess $(0.01-0.02 \%)$ of that calculated to be hydrogenous on this basis, so we have calculated all $\mathrm{MnO}$ to be hydrogenous, even for those four samples.

$\mathrm{Fe}_{2} \mathrm{O}_{3}$ resides in the pelagic clay, hydrogenous, and metalliferous fractions. Figure 5 plots $\mathrm{Fe}_{2} \mathrm{O}_{3}$ versus $\mathrm{Al}_{2} \mathrm{O}_{3}$ and shows that most of the samples plot near the ratio for Pacific pelagic clay (Bischoff, Heath, et al., 1979). The iron in those samples that plot above the line is considered to be combined metalliferous and hydrogenous in the calculation. Since a few samples plot below the line, however, resulting in negative metalliferous + hydrogenous $\mathrm{Fe}_{2} \mathrm{O}_{3}$ abundances, it is clear that pelagic clay must be somewhat variable in composition. For purposes of calculation we have assumed that the ratio $\mathrm{Fe}_{2} \mathrm{O}_{3}$ / $\mathrm{Al}_{2} \mathrm{O}_{3}$ in Panama Basin pelagic clay is 0.40 , rather than the 0.46 of Pacific pelagic clay. This corresponds to the ratio given by plotting a line through the least iron-rich sample in Figure 5. These reduced iron values cannot be the result of the addition of ash to the samples; as indicated by the line giving the $\mathrm{Fe}_{2} \mathrm{O}_{3} / \mathrm{Al}_{2} \mathrm{O}_{3}$ ratio for average Leg 69 ash and the arrow, a considerable quantity of ash (about $20 \%$ ) would be required to shift the ratio for a typical sample toward that of assumed Panama Basin pelagic clay. The higher $\mathrm{Al}_{2} \mathrm{O}_{3}$ of the latter may reflect the larger amount of illite and kaolinite in proportion to the amount of montmorillonite in airborne dust, the source of which is quite near (the volcanoes of Central and South America; see Griffin and Goldberg, 1963, and Prospero, 1981), or in waterborne materials (Heath et al., 1974; Donnelly, 1982). However, by using a lower ratio, there is at least some metalliferous component calculated to be in every sample except the one used to establish the ratio; this guarantees that no sample has a negative calculated metalliferous component. In Figure 5 , we have also plotted the line corresponding to the $\mathrm{Fe}_{2} \mathrm{O}_{3} / \mathrm{Al}_{2} \mathrm{O}_{3}$ ratio for average Deep Ocean Mining Environmental Study (DOMES) pelagic clay (Bischoff, Heath, et al., 1979). This ratio is even higher than that of Pacific pelagic clay. In all likelihood, the range between the assumed composition of Panama Basin pelagic clay and that of the DOMES pelagic clay reflects real variations in both time and space, and it is impossible to conclude that there is any metalliferous component in samples that range through $6 \mathrm{~m} . \mathrm{y}$. of geologic history and plot between these two extremes. In Hole 504, the only possible exceptions are a few samples from Subunit $\mathrm{Ib}$, which consistently have higher $\mathrm{Fe}_{2} \mathrm{O}_{3} / \mathrm{Al}_{2} \mathrm{O}_{3}$ than other samples.

The actual amount of "excess" $\mathrm{Fe}_{2} \mathrm{O}_{3}$ is calculated by subtracting from total $\mathrm{Fe}_{2} \mathrm{O}_{3}$ the amount that belongs to the pelagic clay component, assuming that $\mathrm{Fe}_{2} \mathrm{O}_{3} / \mathrm{Al}_{2} \mathrm{O}_{3}$ equals 0.4 . An additional small amount of $\mathrm{Fe}_{2} \mathrm{O}_{3}$ is then assigned to the hydrogenous component, assuming that $\mathrm{Fe}_{2} \mathrm{O}_{3} / \mathrm{MnO}$ equals 0.32 , the value in the manganese nodules (Bischoff, Heath, et al., 1979). In the Hole 504 sediments, this is no more than $0.13 \%$ $\mathrm{Fe}_{2} \mathrm{O}_{3}$. The resulting quantity, "metalliferous" $\mathrm{Fe}_{2} \mathrm{O}_{3}$

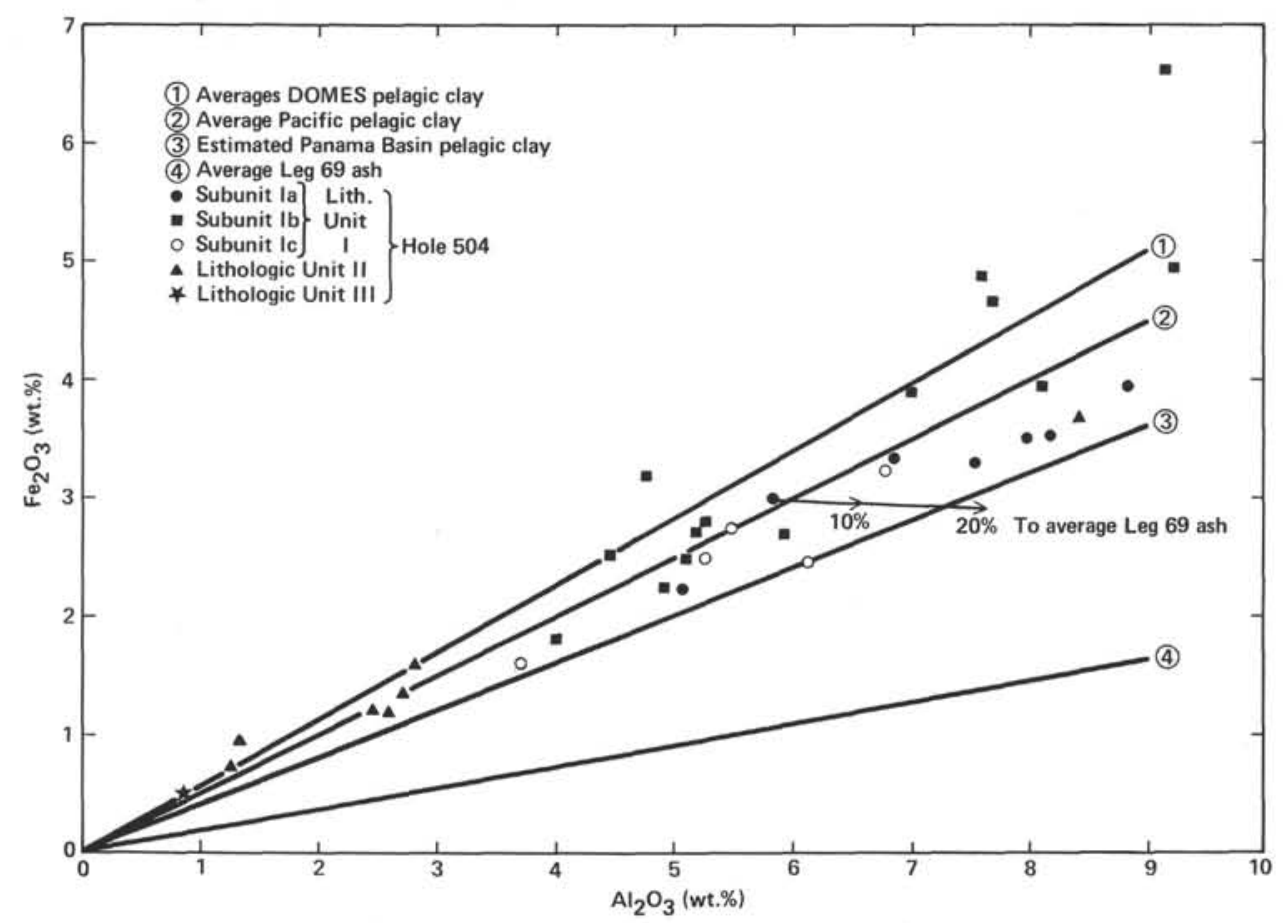

Figure 5. $\mathrm{Fe}_{2} \mathrm{O}_{3}$ versus $\mathrm{Al}_{2} \mathrm{O}_{3}$ for the Hole 504 sediment samples in Table 5. Lines give $\mathrm{Fe}_{2} \mathrm{O}_{3} / \mathrm{Al}_{2} \mathrm{O}_{3}$ ratios for DOMES and Pacific pelagic clay (Bischoff, Heath, et al., 1979), proposed Panama Basin pelagic clay (see text), and average Leg 69 ash (Table 5). 
(excess $\mathrm{Fe}_{2} \mathrm{O}_{3}-0.32 \mathrm{MnO}$ ), is plotted against "excess" $\mathrm{SiO}_{2}$ in Figure 6. The latter is total $\mathrm{SiO}_{2}-3.3 \mathrm{Al}_{2} \mathrm{O}_{3}$, where 3.3 is the ratio of $\mathrm{SiO}_{2} / \mathrm{Al}_{2} \mathrm{O}_{3}$ in average Pacific pelagic clay (Bischoff, Heath, et al., 1979). The slightly higher "metalliferous" $\mathrm{Fe}_{2} \mathrm{O}_{3}$ contents of some Subunit Ib samples are still apparent, but a truer idea of their significance can be seen in the Figure 6 inset, where the abscissa is not nearly so expanded and on which fields for two other DSDP sites are shown. The ratios of $\mathrm{SiO}_{2}$ / $\mathrm{Fe}_{2} \mathrm{O}_{3}$ for the metalliferous sediments from eastern $\mathrm{Pa}$ cific DOMES Site C (Bischoff, Heath, et al., 1979), the Bauer Deep, and the Galapagos mounds hydrothermal field (e.g., Hekinian et al., 1980) are indicated in the fig- ure. Excess $\mathrm{SiO}_{2}$ at Sites 425 (north of the Galapagos Rift in the Panama Basin; Fig. 1) and 504 is clearly dominated by biogenic silica, and compared with Site 420 (at $9^{\circ} \mathrm{N}$, near the crest of the East Pacific Rise), there is hardly any metalliferous component at all, even in samples from Subunit Ib.

Bischoff, Heath, et al. (1979) assigned a certain amount of $\mathrm{SiO}_{2}$ to the metalliferous component in the DOMES area on the basis of analyses of particularly metalliferous sediments from DOMES Site $\mathrm{C}$, which plot close to the trend line of the Figure 6 inset. However, because a number of samples from Site 420 plot below this trend line, Hekinian et al. (1980) inferred that the metallifer-

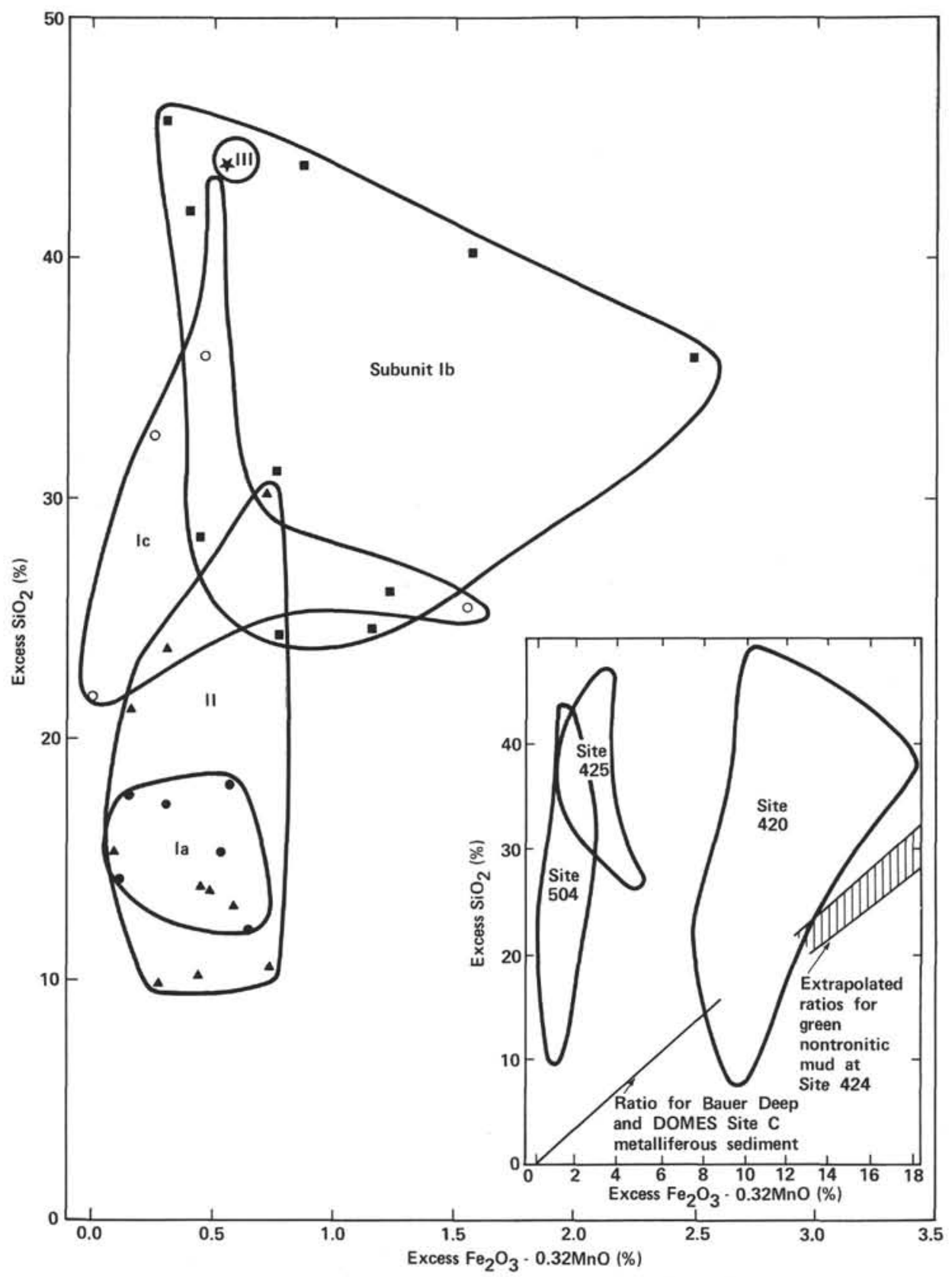

Figure 6. Excess $\mathrm{SiO}_{2}$ versus "'metalliferous" $\mathrm{Fe}_{2} \mathrm{O}_{3}$ (excess $\mathrm{Fe}_{2} \mathrm{O}_{3}-0.32 \mathrm{MnO}$ ) for Hole 504 sediment samples in Table 5. Symbols are as in Figure 5. 
ous component in those sediments was equivalent to the East Pacific Rise iron-hydroxide facies of Boström and Peterson (1966) and Boström et al. (1969), which is notably poor in both $\mathrm{Al}_{2} \mathrm{O}_{3}$ and $\mathrm{SiO}_{2}$. Sediments from DOMES Site $\mathrm{C}$ and the Bauer Deep were interpreted by Hekinian et al. (1980) to be equivalent to the Galapagos mounds iron-nontronite facies, which has nearly fixed ratios of $\mathrm{SiO}_{2} / \mathrm{Fe}_{2} \mathrm{O}_{3}$ and $\mathrm{MgO} / \mathrm{Fe}_{2} \mathrm{O}_{3}$. This facies, if it is like the mounds occurrence, is a local off-axis geothermal precipitate that formed at comparatively low temperatures, unlike the one produced in the high-temperature East Pacific Rise or Costa Rica Rift geothermal regimes (Hekinian et al., 1980). The Site 420 metalliferous component, by contrast, probably precipitated from plumes that were produced at axial hot springs and that originally were highly charged with metalliferous components. These plumes can be traced for thousands of kilometers away from the spreading centers by means of dispersed helium, manganese, and methane (e.g., Lupton et al., 1977, and 1979).

At any rate, the low potential for a metalliferous component in the Site 504 sediment samples makes it impossible to determine from the chemical analyses which facies might have been involved. For simplicity, and because it seems more likely, we have assumed that the small calculated Site $\mathbf{5 0 4}$ metalliferous component is equivalent to the iron-hydroxide facies rather than the iron-nontronite facies. The slight increase in the metalliferous component in the upper Pliocene sediments (Subunit Ib) may have occurred because Site 504 was then closer to the Ecuador Rift (see Fig. 1) than at any other time. If it is assumed that the component is an iron hydroxide, all excess $\mathrm{SiO}_{2}$ (that not in pelagic clay) is biogenic $\mathrm{SiO}_{2}$. Even if the alternative assumption were made, however, the maximum metalliferous $\mathrm{SiO}_{2}$ that would be calculated for any sample would be $4.18 \%$, with most samples having between 1 and $2 \%$.

With this simplification, we calculated the proportions of the principal components of the Hole 504 sediments from their chemical analyses (Table 5). Biogenic $\mathrm{SiO}_{2}$ is all excess $\mathrm{SiO}_{2} . \mathrm{CaCO}_{3}$ is $\mathrm{CaO} \times 1.61$ (adjusting for stoichiometric $\mathrm{CO}_{2}$ ), pelagic clay is $\mathrm{Al}_{2} \mathrm{O}_{3} \times 6.06$, and hydrogenous metals are $\mathrm{MnO} \times 3.12$ (values of factors for $\mathrm{Al}_{2} \mathrm{O}_{3}$ and $\mathrm{MnO}$ are from Bischoff, Heath, et al., 1979, table 4). Metalliferous sediment is excess $\mathrm{Fe}_{2} \mathrm{O}_{3}-0.32 \mathrm{MnO}$ (we have not used the factor of 3.13 of Bischoff, Heath, et al., 1979, because we assume that this component is an iron hydroxide). These proportions are plotted versus depth in Figure 7, after being normalized to $100 \%$. The hydrogenous and metalliferous components have been added for the purposes of the figure, and apart from the small fluctuation in Subunit $\mathrm{Ib}$, they are clearly only a minor portion of the Hole 504 sediments, even when combined.

The proportions of biogenic $\mathrm{SiO}_{2}$, calcium carbonate, and pelagic clay dominate the composition of the sediment, and the fluctuations in these components correspond well to the variations observed in sediment lithology and the results of smear slide and coarse fraction analysis. The low $\mathrm{CaCO}_{3}$ abundances in the Subunit $\mathrm{Ib}$ sediments and the rapidity and extent of fluctua- tions in the biogenic silica and pelagic clay components are clearly manifest in the sharp color fluctuations of that subunit. The higher carbonate content of the Subunit Ia and Lithologic Unit II sediments detected by several procedures show up well here. The most valuable information provided by Figure 7, however, is a quantitative estimate of the size of the biogenic $\mathrm{SiO}_{2}$ and clay fractions. The clay fraction has increased overall since the Miocene, although excursions of 10 to $15 \%$ from sample to sample are common and a decline occurred in the late Pliocene. There are similar excursions in the biogenic $\mathrm{SiO}_{2}$ fraction, but there is no mistaking the broad peak centered on the upper Pliocene in this fraction. In Figure 7, this corresponds to a drop in the proportion of both carbonate and pelagic clay. In the Miocene and lower Pliocene, however, carbonate is clearly dominant, and both the pelagic clay and biogenic $\mathrm{SiO}_{2}$ fractions are reduced in size. We shall return to the consideration of these fluctuations when we discuss carbonate, noncarbonate, and bulk accumulation rates.

Among the minor elements (Table 6), $\mathrm{Sr}$ shows a strong positive correlation with $\mathrm{CaCO}_{3}$ in the Hole 504 samples, with the exception of the sample from Lithologic Unit III. Sr therefore appears to be low in abundance in the pelagic clay and hydrogenous components, although it may have been mobilized in the basal sediments, which have been subjected to high temperatures and extensive diagenesis. $\mathrm{Cu}$ and $\mathrm{Zn}$ are present in abundances in excess of those that would be predicted by the size of the pelagic clay component in the samples if the predictions were based on the abundances of these metals in average pelagic clay (see Cronan, 1969, for $\mathrm{Cu}$ and Turekian and Wedepohl, 1961, for $\mathrm{Zn}$; cited in Bischoff, Heath, et al., 1979, table 2). However, the high $\mathrm{SO}_{3}$ content of the sediment and the abundance of pyrite observed in the smear slides and coarse fraction samples suggest that through biogenic reduction the sulfate in the seawater has become fixed as pyrite in the sediments, a factor that also dominates the alkalinity of the sediment pore fluids at Site 505 (Mottl, Lawrence et al., this volume). $\mathrm{Cu}, \mathrm{Zn}$, and other trace metals could therefore well have been scavenged from seawater during this process (e.g., Goldberg, 1957).

$\mathrm{Ba}$ does not correlate particularly well with either $\mathrm{CaCO}_{3}$ or $\mathrm{Al}_{2} \mathrm{O}_{3}$ (the measure of the pelagic clay component); hence, it appears to have been contributed by more than one fraction. Bischoff, Heath, et al. (1979) attributed it mainly, and about equally, to the hydrogenous and biogenic components, with a small but significant portion to the "detrital" component. X-ray diffraction data (Beiersdorf and Rösch, this volume) indicate that marine barite is a pervasive minor component of the sediments in Holes 504 and 505. Mo, U, and Sn have their highest abundances in Subunit Ib, and in fact one sample in this interval (that from Core 17, Section 3) has the highest abundances of $\mathrm{Cu}, \mathrm{Mo}, \mathrm{Ni}, \mathrm{Co}, \mathrm{Cr}$, $\mathrm{U}, \mathrm{Sc}$, and $\mathrm{V}$ of all the samples analyzed. Most of these metals clearly belong to the metalliferous and hydrogenous fractions. There is no correlation between the abundance of Mo and that of $\mathrm{Pb}$, as there is in the DOMES sediments, where both elements have been included in 


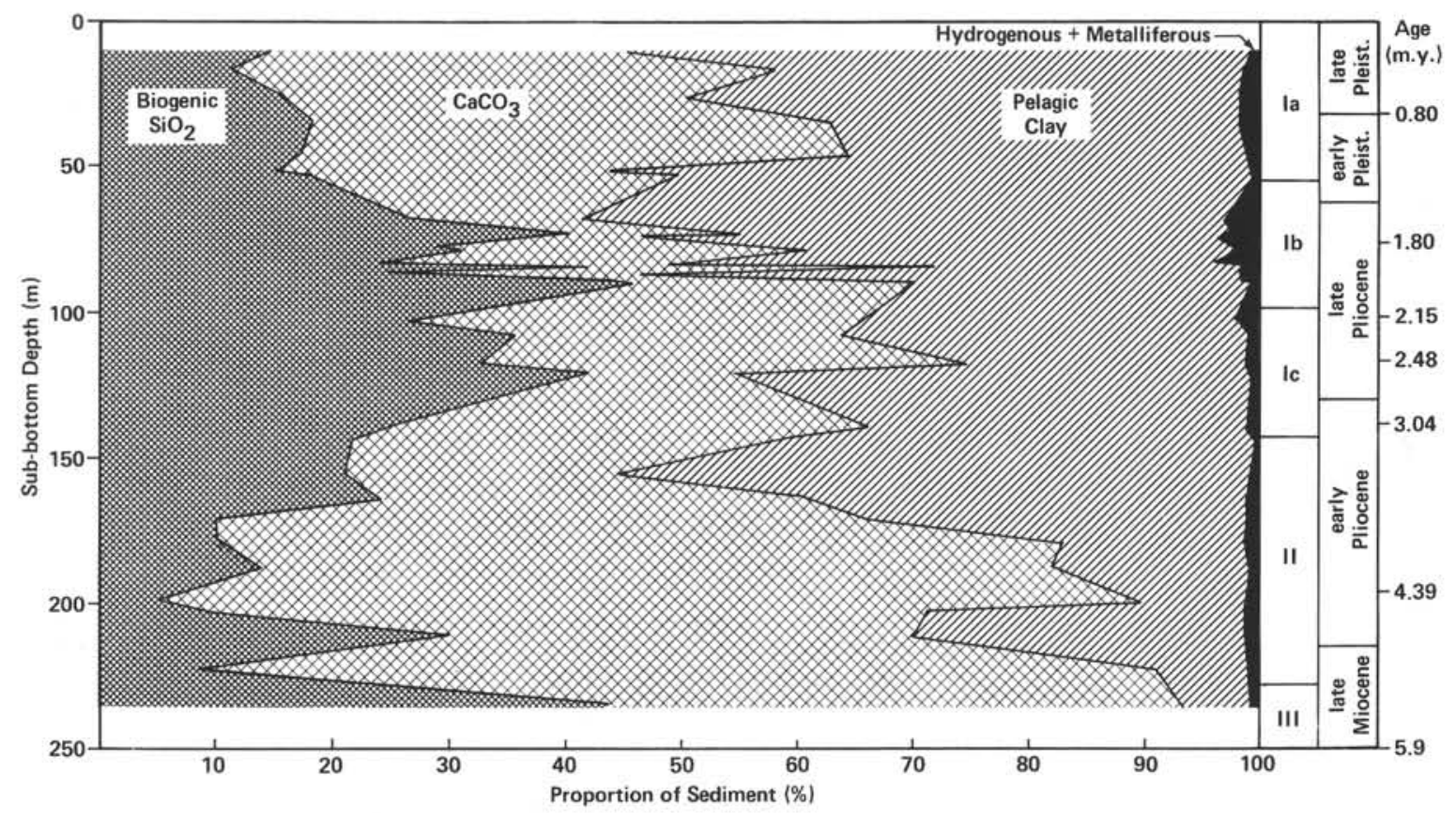

Figure 7. Proportions of principal sediment components in Hole 504 calculated from the compositions of Table 5.

the hydrogenous fraction (Bischoff, Piper, et al., 1979). At Site 504, again, biological factors may have selectively affected $\mathrm{Pb}$ abundances.

Finally, there are strong correlations between $\mathrm{Al}_{2} \mathrm{O}_{3}$ and $\mathrm{TiO}_{2}, \mathrm{~V}$, and (to a lesser extent) Sc, indicating that the abundances of these oxides and trace elements are controlled largely by the size of the pelagic clay fraction in the sediments.

The sample from Site 505 is a mudline sample (i.e., from the very top of the sediments). The sediments are very dark grayish brown. The principal sediment components (normalized to $100 \%$ ) are given in Table 5. The high $\mathrm{MnO}$ content may reflect near-surface diagenetic mobilization (e.g., Bonatti and Joensuu, 1966).

\section{SEDIMENTOLOGY OF SITE 505}

\section{Lithologic Units}

The sequence of sediments at Site 505 consists of three lithologic units (Fig. 8). Unit I, at 0 to 14.50 meters sub-bottom, is made up of upper Pleistocene calcareous marl. Unit II, at 14.50 to 133.50 meters subbottom, is upper Pleistocene to upper Pliocene variably clay-bearing nannofossil siliceous ooze. Unit III, at 133.50 to 232 meters sub-bottom, is upper to lower Pliocene siliceous nannofossil ooze.

\section{Sedimentary Structures}

Drilling disturbance due to rotary coring appears in the sediment as diapiric and flow structures. It is intense and has destroyed most of the original sedimentary structures. However, a few of the structural features were left intact. These features and the intense bioturbation visible in the piston-cored sediments of nearby Site 504 make it obvious that the sediments at Site 505 are bioturbated throughout.
Volcanic ash layers at $3.66,16.45,16.75$, and 26.40 meters sub-bottom are the only examples of simple bedding. Zoophycos burrows occur mainly between 10 and 143 meters sub-bottom (Fig. 8). In addition, a few burrow halos similar to those at Site 504 occur in Lithologic Unit III; they become more frequent with increasing depth. Color changes, changes in $\mathrm{CaCO}_{3}$ content, and changes in the bulk composition of the sediments are gradational. Judging from the characteristics of the sediments at Site 504 this is not a mechanical effect of drilling.

Color changes are frequent in Lithologic Units I and II, particularly at depths between 20 and 40 meters subbottom (17 layers). Toward the base of the sediments the frequency of the color changes decreases to about two changes per 10-meter interval. As at Site 504, color changes are most frequent where fluctuations in bulk composition are most rapid.

\section{Grain-Size Distribution}

Table 7 and Figure 8 present the grain-size distribution of the sediments at Site 505. For visual estimates of the clay-size fraction $(<2 \mu \mathrm{m})$ the same low accuracy can be expected as at Site 504 .

The proportion of the $<2 \mu \mathrm{m}$ fraction is largest in Lithologic Unit I, where it averages $39 \%$ of the sediment (Fig. 8). In Lithologic Unit II, it is always less than $25 \%$ (and averages $10 \%$ ) down to a depth of 72 meters sub-bottom. Between 72 and 119 meters sub-bottom the percentages of the clay-sized fraction increase again, reaching another maximum of $40 \%$. The average for this interval is $24 \%$. These high percentages contain some uncertainty because of the uncored intervals. In the remaining part of Lithologic Unit II the clay-sized percentage averages $13 \%$ and is always less than $25 \%$. The average for Lithologic Unit III is $8 \%$. In this unit 
the percentages decrease generally with depth from about $20 \%$ to $5 \%$.

The proportion of the sediment that is fine to medium-sized silt (2-32 $\mu \mathrm{m})$ ranges between 35 and $85 \%$ and is almost exactly inversely correlated with the size of the clay-sized fraction, because the fraction $>32 \mu \mathrm{m}$ shows only a slight variation (2-12\%). Only in Lithologic Unit I is the clay-sized fraction greater than the fine to medium silt-sized fraction. In the remaining sediments the fine to medium silt-sized fraction is always the largest grain-size fraction.

The size of the coarse silt (32-64 $\mu \mathrm{m})$ fraction is usually somewhat greater than that of the sand-sized $(>63 \mu \mathrm{m})$ fraction, but it is never greater than $10 \%$. A higher percentage of coarse silt-sized material occurs within the upper 56 meters (average: $4 \%$ ). Below this depth the average is $3.5 \%$. The highest percentage of sand-sized material occurs within the upper 16 meters, where the average is $7 \%$, and at the base of the sediments, where the average is $8 \%$. Between these extremes the percentage is always less than $5 \%$.

All of the grain-size fractions have their greatest fluctuations within Lithologic Units I and II. The greatest variations in the size of the coarse silt and sand-sized fractions occur between 20 and 56 meters sub-bottom (the upper part of Lithologic Unit II). The clay-size fraction has its greatest fluctuation between 95 and 120 meters sub-bottom (the lower part of Lithologic Unit II).

\section{Smear Slide Summary}

Since the sediments at Site 505 are similar to those of Site 504, the Site 505 smear slide data are presented in the same way (Table 8 and Fig. 9).

Planktonic and benthic foraminifers occur throughout the sediment sequence. As at Hole 504, benthic foraminifers rarely reach $2 \%$ of the total foraminifer assemblages. Foraminifers are most abundant in Lithologic Unit I, except in its uppermost part. A maximum abundance of $18 \%$ occurs at the base of this unit. In Lithologic Units II and III foraminifers occur in variable amounts from trace abundances to $10 \%$.

In Lithologic Unit I, unspecified carbonate is usually less than $3 \%$ of the sediment composition. In the upper part of Lithologic Unit II, to a depth of about 70 meters sub-bottom, there are rather high percentages of unspecified carbonate (average: $10 \%$ ). In the remaining part of the unit it is significantly lower. In the upper part of Lithologic Unit III, to a depth of about 170 meters sub-bottom, the unspecified carbonate percentages are approximately as high as in the upper part of Lithologic Unit II. From 170 to 220 meters sub-bottom the percentages range between 5 and $10 \%$. Below this, there is a drastic increase in unspecified carbonate, an increase that correlates with the increasing firmness of the sediment. The highest abundance $(\mathbf{4 0 \%})$ is at the basalt/ sediment contact.

In Lithologic Unit I, calcareous nannofossils form from 10 to $40 \%$ of the sediment. Only within the clayrich interval of Unit II do such low values occur again. In the remaining sediments, nannofossils are always more abundant than $50 \%$, with maximum percentages between 70 and $80 \%$.

The siliceous biogenic fraction varies between 8 and $30 \%$; in most cases it is about $20 \%$.

The distribution of clay is the same as for the claysize fraction, with the same uncertainty regarding its abundance as discussed for Site 504. "Other components," as described for Site 504, form generally less than $7 \%$ of the total sediment. Siliceous volcanic glass and authigenic pyrite are present throughout the sequence. The highest concentrations of volcanic glass are within the upper 30 meters, where it can form 2 to $3 \%$ of the total composition. Chitinous copepod fragments are restricted to the uppermost sediments. Toward the base of Lithologic Unit III there is an increase in basaltic volcanic glass. Other components occur as traces and are randomly distributed.

\section{Calcium Carbonate Content}

Table 9 presents the calcium carbonate $\left(\mathrm{CaCO}_{3}\right)$ content determined by the "Karbonat Bombe" method. The data show the same general trend as the optically determined curve for total carbonate (foraminifers + unspecified carbonate + calcareous nannofossils) in Figure 8 (the smear slide summary). Differences are very likely caused by the same factors as at Site 504 (difficulty of estimating percentages optically and sample-tosample variations). Values of calcium carbonate content of less than $20 \%$ can be found within the upper 40 meters and between 100 and 120 meters sub-bottom, depths that correspond to the clay-rich interval. From 120 meters downward there is a general increase in $\mathrm{CaCO}_{3}$ percentages to values between 60 and $70 \%$. The strongest fluctuations in percentages occur within the upper 50 meters of the sequence.

\section{Coarse Fraction Analysis}

The composition of the coarse fraction ( $>63 \mu \mathrm{m}$ ) of the Site 505 sediments (Table 10 and Fig. 9) is similar to that of Site 504. Both the constituents and their relative frequencies are approximately the same, as well as the degree of fluctuation in the individual components.

Foraminifers, foraminifer fragments, and radiolarians are dominant constituents of the coarse fraction and always total more than $70 \%$. The percentages of unbroken foraminifers vary for the most part between 5 and $15 \%$. Percentages at the low end of this range ( 5 to $10 \%$ ) characterize depths between 100 and 130 meters sub-bottom.

The highest percentage of foraminifer fragments $(66 \%)$ is found in Lithologic Unit I. From this maximum, percentages decrease considerably to approximately $24 \%$ at the top of Lithologic Unit II. From there they increase again and vary only little around an average of $35 \%$. Between 80 and 180 meters sub-bottom, they rarely exceed $30 \%$. Between the latter depth and the base of the sediments the percentages of foraminifer fragments are generally greater than $30 \%$.

Since the size of the unbroken foraminifer test proportion is consistently low, the curve for total foraminiferal material is very similar to that for the foraminifer 


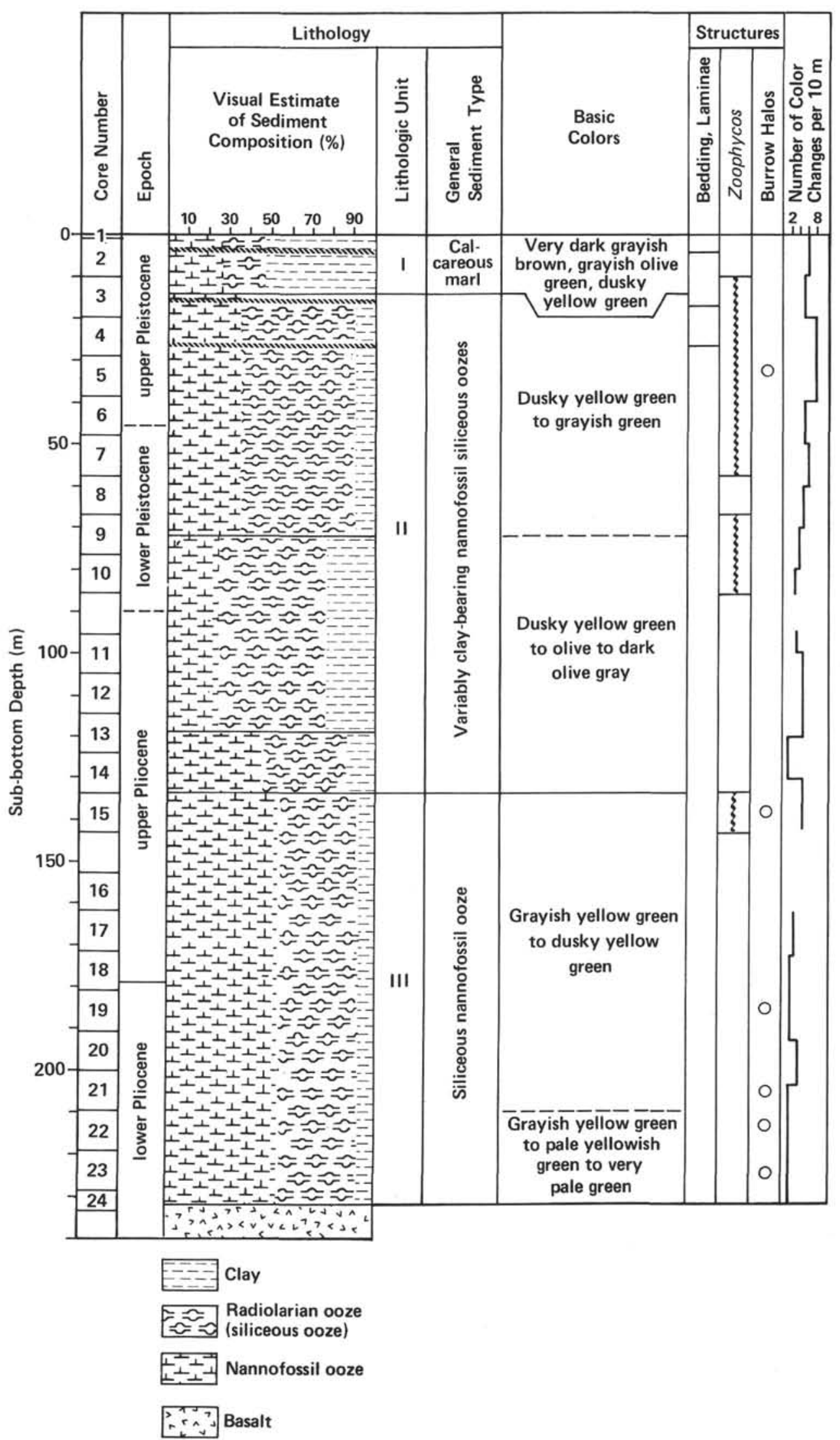

Figure 8. Summary of lithology, composition, texture, and calcium carbonate content of the sediments of Hole 505 . 

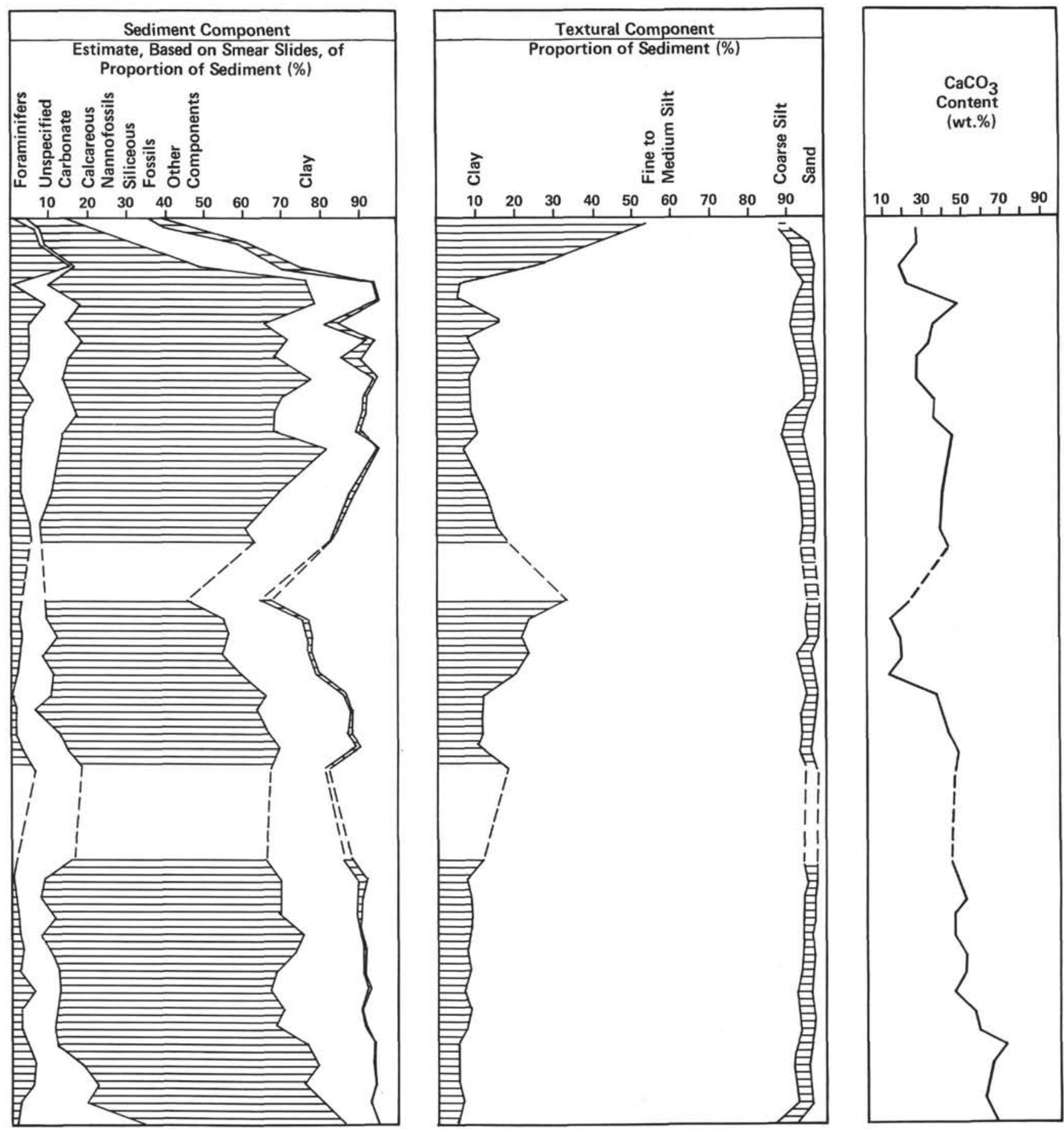

Figure 8. (Continued). 
Table 7. Grain-size distribution for sediments at Hole 505.

\begin{tabular}{|c|c|c|c|c|}
\hline Core & Section & $\begin{array}{c}\text { Clay } \\
(<2 \mu \mathrm{m}) \\
(\%)^{\mathrm{a}}\end{array}$ & $\begin{array}{c}\text { Coarse Silt } \\
(32-63 \mu \mathrm{m}) \\
(w \mathrm{t} . \%)\end{array}$ & $\begin{array}{c}\begin{array}{c}\text { Sand } \\
(>63 \mu \mathrm{m})\end{array} \\
\text { (wt. } \%)\end{array}$ \\
\hline 1 & 1 & 52 & & \\
\hline 2 & $1-3$ & 40 & 2.1 & 9.4 \\
\hline 2 & $4-5$ & 38 & 4 & 4.9 \\
\hline 3 & $1-3$ & 26 & 5.8 & 3.1 \\
\hline 3 & 5 & 6 & 2.2 & 3.4 \\
\hline 4 & $2-3$ & 13 & 4.6 & 3.2 \\
\hline 4 & $4-7$ & 16 & 5.4 & 3.2 \\
\hline 5 & $1-3$ & 8 & 4.6 & 3.6 \\
\hline 5 & $4-6$ & 11 & 4.0 & 2.6 \\
\hline 6 & $1-3$ & 8 & 3.3 & 2.0 \\
\hline 6 & $4-7$ & 9 & 2.8 & 2.4 \\
\hline 7 & $1-3$ & 9 & 4.4 & 4.5 \\
\hline 7 & $4-6$ & 11 & 5.6 & 5.9 \\
\hline 8 & 1 & 7 & 0 & 0 \\
\hline 9 & $1-3$ & 12 & 3.9 & 2.9 \\
\hline 10 & $1-3$ & 15 & 3.2 & 2.4 \\
\hline 10 & $4-5$ & 18 & 3.4 & 2.7 \\
\hline 11 & $1-3$ & 34 & 3 & 1.4 \\
\hline 11 & $4-6$ & 24 & 3.5 & 1.3 \\
\hline 12 & $1-3$ & 22 & 3 & 1.5 \\
\hline 12 & 4 & 24 & 3.9 & 3.8 \\
\hline 13 & $1-3$ & 21 & 3.4 & 2.6 \\
\hline 13 & $4-6$ & 13 & 2.9 & 1.9 \\
\hline 14 & $1-3$ & 12 & 3.7 & 2.2 \\
\hline 14 & $4-5$ & 12 & 2.8 & 2.8 \\
\hline 15 & $2-3$ & 11 & 3.2 & 3.2 \\
\hline 15 & $4-6$ & 18 & 3.1 & 1.8 \\
\hline 17 & $1-3$ & 12 & 3.6 & 2 \\
\hline 17 & $4-8$ & 8 & 2.7 & 1.6 \\
\hline 18 & $1-3$ & 9 & 2.8 & 2.1 \\
\hline 18 & $4-6$ & 9 & 2.3 & 2.1 \\
\hline 19 & $1-3$ & 9 & 2.3 & 2.9 \\
\hline 19 & $4-7$ & 8 & 3.5 & 2.1 \\
\hline 20 & $1-3$ & 9 & 3.5 & 2.2 \\
\hline 20 & $4-7$ & 7 & 3.7 & 2.8 \\
\hline 21 & $1-3$ & 9 & 3.1 & 2.2 \\
\hline 21 & $4-8$ & 8 & 3.2 & 1.9 \\
\hline 22 & $1-3$ & 6 & 4 & 2.4 \\
\hline 22 & $4-6$ & 6 & 4.2 & 3.2 \\
\hline 23 & $1-3$ & 6 & 4.3 & 2.8 \\
\hline 23 & $4-6$ & 7 & 3.7 & 2.5 \\
\hline 24 & $1-2$ & 6 & 5.6 & 6.2 \\
\hline
\end{tabular}

a Visual estimate.

fragments. The curve for radiolarian percentages varies roughly inversely to these.

Diatom percentages are highest between 50 and 75 meters sub-bottom (5-10\%). Elsewhere they form less than $5 \%$ of the coarse fraction. Fish debris shows no particular trend and is always less than $2 \%$. Pellets rarely exceed trace amounts. However, their percentages were plotted because of their significance in determining the degree of diagenesis. Other biogenic components occur as traces only. Within this fraction the proportion of sponge spicules exceeds that of echinoderm spicules. Ostracods occur in two samples only. An unusually high proportion of chitin, up to $15 \%$, occurs in Core 1 . Most of it is fragments, but it consists in part of chaetognath worm jaws and copepod limb segments (written communication, C. Sancetta, 1981) (Plate 3, Fig. 10).
The proportion of silicic volcanic glass is below $5 \%$ for most of the coarse fraction samples. Higher abundances occur only in the immediate vicinity of the ash layers and at sub-bottom depths between 96 and 98 meters, at 121 meters, and between 175 and 178 meters. The increased proportion of volcanic glass at the base of the sediment sequence is due to a high proportion of brown basaltic glass, as mentioned in the smear slide summary. Biotite is more abundant where the silicic glass content of the coarse fraction is high. Plagioclase is more abundant in Lithologic Unit III than elsewhere. Quartz occurs only between 70 and 185 meters sub-bottom. Pyrite occurs in the same form as in the coarse fractions of Lithologic Units I and II of Site 504. It varies between trace abundances and $6 \%$ and is higher in the upper part of Lithologic Unit II than elsewhere.

\section{DISCUSSION}

\section{Provenance of Sediment Components}

The sediments at Sites 504 and 505 àre mainly calcareous, with high proportions of calcareous nannofossils, foraminifers, and foraminifer fragments. Opaline silica in the form of radiolarians, diatoms, silicoflagellates, and sponge spicules, as well as fine inorganic detritus, make up the remainder. The biogenic components stem mainly from planktonic organisms living in a highly productive marine environment. Only a very small fraction of the foraminifers is benthic.

Thin layers of silicic volcanic ash occur in upper Pleistocene sediments at both sites and in lower Pliocene sediments at Site 504, where older sediments were reached than at Site 505. However, the occurrence of silicic glass and volcanic minerals throughout the sediments as far down as the upper Miocene suggests a more or less regular input of airborne ash. As discussed earlier, the most important sources of airborne ash are the highly active volcanoes of the Central and (more particularly) the South American magmatic arcs rather than the volcanoes of the Galapagos Islands, some of which produce silicic lava flows. The presence of compact ash beds in the upper Pleistocene and lower Pliocene sediments but not elsewhere suggests that these periods represent times of increased explosive volcanism in the Central and South American arcs.

The basaltic glass that is common near the base of the sediments at Site 505 was probably derived from the chilled glassy margins of the nearby basalt outcrops or from glassy submarine breccias.

Smectite, the dominant clay mineral at both sites (Beiersdorf and Rösch, this volume), is very likely of continental origin or is authigenic after an originally mixed assemblage of clays of continental origin. In that case it would have been transported to the sites by either water or wind. The smectite may also be partially an alteration product of volcanic debris, but the presence of only fresh volcanic glass and the lack of shard pseudomorphs makes this doubtful.

The pyrite found throughout the sediment columns of both sites is clearly an authigenic product. The green 
Table 8. Smear slide abundances in sediments from Hole 505.

\begin{tabular}{|c|c|c|c|c|c|c|c|c|c|c|c|}
\hline Core & Sections & $\begin{array}{c}\text { Fora- } \\
\text { minifers }\end{array}$ & $\begin{array}{l}\text { Unspecified } \\
\text { Carbonate }\end{array}$ & $\begin{array}{c}\text { Calcareous } \\
\text { Nanno- } \\
\text { fossils }\end{array}$ & $\begin{array}{l}\text { Radio- } \\
\text { larians }\end{array}$ & Diatoms & $\begin{array}{c}\text { Silico- } \\
\text { flagellates }\end{array}$ & $\begin{array}{l}\text { Sponge } \\
\text { Spicules }\end{array}$ & $\begin{array}{c}\text { Total } \\
\text { Siliceous } \\
\text { Fossils }\end{array}$ & $\begin{array}{c}\text { Other } \\
\text { Components }\end{array}$ & Clay \\
\hline
\end{tabular}

\begin{tabular}{|c|c|c|c|c|c|c|c|c|c|c|c|}
\hline \multirow[b]{2}{*}{1} & \multirow[b]{2}{*}{1} & \multicolumn{10}{|c|}{ Average Abundance per Half Core $(\%)$} \\
\hline & & 2 & 3 & 10 & 10 & 10 & 1 & $\mathrm{Tr}$ & 21 & 4 & 60 \\
\hline 2 & $1-3$ & 6.3 & 1.5 & 12.5 & 8.5 & 9 & 1.5 & 1.3 & 20.3 & 6.9 & 52.5 \\
\hline 2 & 4-6 & 8 & 0.2 & 23.3 & 9.3 & 13.3 & 2 & 3 & 27.6 & 2.6 & 38.3 \\
\hline 3 & $1-3$ & 16.7 & 0.3 & 32 & 7.8 & 7.8 & 1.5 & 3.3 & 20.4 & 5.6 & 25 \\
\hline 3 & 4-CC $\mathrm{Ca}^{\mathrm{a}}$ & 0.7 & 8.3 & 67 & 5.3 & 6.7 & 1.3 & 3.3 & 16.6 & 0.7 & 6.7 \\
\hline 4 & $1-3$ & 9.3 & 8.8 & 61.3 & 6.3 & 5.3 & 1.5 & 2.8 & 15.9 & 0.3 & 5 \\
\hline 4 & 4-7 & 5 & 9.6 & 50.4 & 5 & 5.4 & 1.6 & 3 & 15 & 4 & 16 \\
\hline 5 & $1-3$ & 4.5 & 13.8 & 53.3 & 7.3 & 8.5 & 1.5 & 3.5 & 20.8 & 1.3 & 6.3 \\
\hline 5 & 4-CC & 5 & 10.5 & 52.5 & 6 & 6 & 1.5 & 3.5 & 17 & 5 & 10 \\
\hline 6 & $1-3$ & 2.7 & 11.7 & 63.3 & 4.7 & 5.7 & 1.7 & 3 & 16.1 & 0.6 & 5.6 \\
\hline 6 & $4-7$ & 6.3 & 9.5 & 54 & 7 & 7 & 2.5 & 4.5 & 21 & 0.9 & 8.3 \\
\hline 7 & $1-3$ & 4.3 & 13.3 & 51.7 & 7.3 & 9 & 2 & 4 & 22.3 & 0.9 & 8.3 \\
\hline 7 & $4-6$ & 3.7 & 10.7 & 53.7 & 7.7 & 8 & 1.7 & 3.7 & 21.1 & 0.8 & 10 \\
\hline 8 & 1-CC & 3 & 10 & 68 & 5 & 5 & 1 & 3 & 14 & 0 & 5 \\
\hline 9 & $1-4$ & 3 & 8 & 59 & 6.3 & 7 & 1.5 & 3 & 17.8 & 0.9 & 11.3 \\
\hline 10 & $1-3$ & 5.3 & 2.3 & 53.5 & 7.8 & 8 & 4 & 3.3 & 23.1 & 0.8 & 15 \\
\hline 10 & 4-CC & 5.5 & 2.5 & 55 & 6.5 & 7.5 & 3 & 2.5 & 19.5 & 0 & 17.5 \\
\hline 11 & $1-3$ & 3.3 & 6.3 & 35.8 & 6.3 & 7.5 & 1.8 & 4.5 & 20.1 & 2 & 32.5 \\
\hline 11 & 4-CC & 2.5 & 7 & 45.5 & 7 & 8 & 1.8 & 4.8 & 21.6 & 0.9 & 22.5 \\
\hline 12 & $1-3$ & 3.3 & 9 & 44.5 & 7.8 & 7.3 & 1.8 & 4 & 20.9 & 1 & 21.3 \\
\hline 12 & $4-5$ & 2.5 & 6 & 46.5 & 5.5 & 7 & 1.5 & 8 & 22 & $i$ & 22.5 \\
\hline 13 & $1-3$ & 2.3 & 9.3 & 47.7 & 7.3 & 8 & 2.7 & 1.7 & 19.7 & 1 & 20 \\
\hline 13 & 4-CC & 1.2 & 9.4 & 55.4 & 6.4 & 10.2 & 0.8 & 3.2 & 20.6 & 0.4 & 13 \\
\hline 14 & $1-3$ & 1.7 & 5 & 57 & 7.7 & 11.7 & 2.3 & 2.7 & 24.4 & 0.2 & 11.7 \\
\hline 14 & 4-CC & 1.7 & 11.7 & 54 & 6 & 10.7 & 1.7 & 1.7 & 20.1 & 0.8 & 11.7 \\
\hline 15 & $1-3$ & 3.3 & 11.7 & 55 & 5.7 & 8 & 2.7 & 3.3 & 19.7 & 0.3 & 10 \\
\hline 15 & 4-CC & 6.7 & 12.3 & 49 & 3.7 & 6.3 & 1.7 & 2 & 13.7 & 0 & 18.3 \\
\hline 17 & $1-3$ & 1.7 & 15 & 50 & 6.7 & 9.3 & 2 & 2 & 20 & 1.6 & 11.7 \\
\hline 17 & 4-CC & 1 & 7.8 & 61.8 & 5 & 9.8 & 2.3 & 3 & 20.1 & 2.5 & 6.8 \\
\hline 18 & $1-3$ & 1.3 & 6.7 & 62.3 & 7 & 6.7 & 2 & 4.3 & 20 & 0.7 & 9 \\
\hline 18 & 4-CC & 2.7 & 7.3 & 58 & 6.7 & 6.7 & 3.3 & 5 & 21.7 & 1.3 & 9 \\
\hline 19 & $1-3$ & 2.7 & 5 & 68.3 & 5.3 & 4.7 & 1.7 & 3.3 & 15 & 0 & 9 \\
\hline 19 & 4-CC & 3.7 & 7 & 63.2 & 5.4 & 6.4 & 1.4 & 4.6 & 17.8 & 0.7 & 7.6 \\
\hline 20 & $1-3$ & 2.7 & 10 & 56.3 & 7.7 & 9 & 1.7 & 4.3 & 22.7 & 0 & 8.3 \\
\hline 20 & 4-CC & 6.6 & 7 & 54.2 & 8.4 & 10 & 2 & 4.8 & 25.2 & 0.4 & 6.6 \\
\hline 21 & $1-3$ & 3 & 9.3 & 58.7 & 7 & 7.3 & 2 & 4.3 & 20.6 & 0.1 & 8.3 \\
\hline 21 & 4-CC & 3.2 & 8.6 & 57.6 & 7.6 & 8.8 & 2.2 & 4.6 & 23.2 & 0 & 7.4 \\
\hline 22 & $1-3$ & 5.3 & 7 & 65.3 & 5.7 & 6 & 1.3 & 4.3 & 17.3 & 0.1 & 5 \\
\hline 22 & 4-CC & 7 & 11.3 & 61.4 & 5 & 5.5 & 1 & 3.3 & 14.8 & 0 & 5.5 \\
\hline 23 & $1-3$ & 6.3 & 16.7 & 53.3 & 5 & 9.3 & 0.7 & 3.7 & 18.7 & 0 & 5 \\
\hline 23 & 4-CC & 2.5 & 17.5 & 61.2 & 3.8 & 4.5 & 1 & 3 & 12.3 & 0 & 6.5 \\
\hline 24 & $1-3$ & 1.7 & 31.7 & 52.3 & 3 & 2.7 & 1 & 2.3 & 9 & 0 & 5.3 \\
\hline
\end{tabular}

color of the sediment and the strong $\mathrm{H}_{2} \mathrm{~S}$ smell at Site 505 suggest that pyrite formed under reducing conditions by anaerobic bacteria. The pyrite is mostly spheroidal and framboidal, and it fills in fossils and burrows (it is second-order pyrite in the sense of Hein and Griggs, 1972). The only solid layer of cubic pyrite crystals, which was found at Site 504 (at $231.30 \mathrm{~m}$ sub-bottom), is very likely a product of the diagenetic transformation of second-order into third-order pyrite (Hein and Griggs, 1972).

Since X-ray diffraction data (Beiersdorf and Rösch, this volume) show only weak signs of laterally reworked sediments (clinoptilolite at Site 505, magnetite and maghemite at both sites), the sediments of both sites are almost entirely autochthonous, although the thickened sequence at Site 505 suggests redeposition from nearby outcrops. Sediment deposition also must have been continuous, since there are no hiatuses. However, deposition was not uniform, as shown by small- and largescale fluctuations in composition and differences in accumulation rates at the two sites.

\section{Accumulation Rates and Depositional History}

We drew accumulation rate curves for both sites by using 11 time slices for Site 504 and 9 time slices for Site
505 (Fig. 10). The boundary horizons for the time slices are diatom levels (Sancetta, this volume), the zero age for the sediment/water interface, and the basement ages for the basalt/sediment contacts inferred from magnetic anomalies (Langseth et al., this volume). The age and thickness of the time slices are given in Tables 11 and 12, as well as average bulk densities and porosities. Sedimentation rates were corrected for water content and compaction as explained in Table 11 to give accumulation rates. The $\mathrm{CaCO}_{3}$ data given in Tables 3 and 9 were averaged per time slice.

For the Site 505 curves, difficulties arose from the uncertainty of the time of the last $R$. praebergonii and $N$. jouseae occurrences (see Sancetta, this volume), which define the time slices on either side of 1.5 and 2.6 Ma. Both diatom levels occur within the two intervals that were not cored because the heat flow tool sank through the sediments. Therefore, two versions of the curves were constructed. For the first, the tops of the respective diatom occurrences were assumed to be in the middle of each uncored interval; for the second, they were taken to coincide with the base of these intervals.

Van Andel et al. (1975) show decreasing equatorial bulk accumulation rates from about $2.5 \mathrm{~g} / \mathrm{cm}^{2} / 1000 \mathrm{yr}$. at $6 \mathrm{Ma}$ to about $1 \mathrm{~g} / \mathrm{cm}^{2} / 1000 \mathrm{yr}$. today. At any given 
Table 9. $\mathrm{CaCO}_{3}$ content of the unconsolidated sediments of Hole 505 .

\begin{tabular}{|c|c|c|}
\hline $\begin{array}{l}\text { Core/Section } \\
\text { (interval in cm) }\end{array}$ & $\begin{array}{l}\mathrm{CaCO}_{3} \\
\text { Content } \\
{\text { (wt. } \%)^{\mathrm{a}}}^{\text {(w) }}\end{array}$ & $\begin{array}{c}\text { Average } \mathrm{CaCO}_{3} \\
\text { Content per Core } \\
\text { (wt. \%) }\end{array}$ \\
\hline $2-2,73-75$ & $38 \mid$ & \\
\hline $2-3,73-75$ & $16\}$ & 27 \\
\hline $2-4,86-88$ & 271 & \\
\hline $3-2,14-16$ & 19 & \\
\hline $3-3,73-75$ & $17\}$ & 19 \\
\hline $3-5,130-132$ & $21 J$ & \\
\hline $4-2,101-103$ & 47 & \\
\hline $4-3,95-97$ & $50\}$ & 44.6 \\
\hline $4-4,71-73$ & 371 & \\
\hline $4-5,84-86$ & 16 & 34.5 \\
\hline $4-7,73-75$ & $53\}$ & \\
\hline $5-1,73-75$ & $39)$ & \\
\hline $5-2,73-75$ & $24\}$ & 33.3 \\
\hline $\begin{array}{l}5-3,73-75 \\
5-4,73-75\end{array}$ & $\begin{array}{l}37) \\
41)\end{array}$ & \\
\hline $5-5,73-75$ & $25\}$ & 28.3 \\
\hline $5-6,73-75$ & 19 ) & \\
\hline $6-1,53-55$ & 25 & \\
\hline $6-2,73-75$ & $34\}$ & 27.6 \\
\hline $6-3,73-75$ & $24)$ & \\
\hline $6-4,73-75$ & $38)$ & \\
\hline $6-5,73-75$ & 50 & 35.5 \\
\hline $6-6,73-75$ & 32 & \\
\hline $6-7,73-75$ & $22 J$ & \\
\hline $7-1,73-75$ & 31 & \\
\hline $7-2,73-75$ & $33\}$ & 35.7 \\
\hline $7-3,73-75$ & $43 J$ & \\
\hline $7-4,73-75$ & 411 & \\
\hline $7-5,73-75$ & $50\}$ & 45.3 \\
\hline $7-6,73-75$ & 451 & \\
\hline $9-1,100-102$ & $44)$ & \\
\hline $9-2,73-75$ & $49\}$ & 40 \\
\hline $9-3,73-75$ & $27)$ & \\
\hline $10-1,73-75$ & 381 & \\
\hline $10-2,73-75$ & $25\}$ & 39.3 \\
\hline $10-3,73-75$ & 551 & \\
\hline $10-4,73-75$ & $52\}$ & 43 \\
\hline $10-5,73-75$ & 341 & 43 \\
\hline $11-1,100-102$ & 31 & \\
\hline $11-2,73-75$ & $25\}$ & 22.7 \\
\hline $11-3,73-75$ & $12)$ & \\
\hline $11-4,73-75$ & $13)$ & \\
\hline $11-5,73-75$ & $10\}$ & 14 \\
\hline $11-6,73-75$ & $19 J$ & \\
\hline $12-2,37-39$ & $13)$ & \\
\hline $12-3,73-75$ & $23\}$ & 18.3 \\
\hline $12-4,73-75$ & $19)$ & \\
\hline $13-1,73-75$ & $14)$ & \\
\hline $13-3,73-75$ & $15\}$ & 14 \\
\hline $13-4,73-75$ & $13)$ & \\
\hline $13-5,73-75$ & $53\}$ & 49.5 \\
\hline $13-6,73-75$ & $46\}$ & \\
\hline $14-2,73-75$ & $44\}$ & 40.5 \\
\hline $14-3,73-75$ & $37\}$ & \\
\hline $14-4,73-75$ & $39\}$ & 43.5 \\
\hline $14-5,73-75$ & $\begin{array}{ll}48 \\
54\end{array}$ & \\
\hline $\begin{array}{l}15-2,123-125 \\
15-3,73-75\end{array}$ & $\left.\begin{array}{l}54 \\
44\end{array}\right\}$ & 49 \\
\hline $15-4,73-75$ & 601 & \\
\hline $15-5,73-75$ & 48 & 46.9 \\
\hline $15-6,26-28$ & $32)$ & \\
\hline $17-2,73-75$ & $40\}$ & 46 \\
\hline $17-3,73-75$ & 521 & \\
\hline $17-4,73-75$ & $42)$ & \\
\hline $17-5,73-75$ & $\left.\begin{array}{l}46 \\
53\end{array}\right\}$ & 50 \\
\hline $17-7,73-75$ & 531 & \\
\hline
\end{tabular}

Table 9. (Continued).

\begin{tabular}{|c|c|c|}
\hline $\begin{array}{l}\text { Core/Section } \\
\text { (interval in cm) }\end{array}$ & $\begin{array}{l}\mathrm{CaCO}_{3} \\
\text { Content } \\
\text { (wt.\%) }{ }^{\mathrm{a}}\end{array}$ & $\begin{array}{c}\text { Average } \mathrm{CaCO}_{3} \\
\text { Content per Core } \\
\text { (wt. \%) }\end{array}$ \\
\hline $18-1,133-135$ & $43\}$ & 52.7 \\
\hline $18-3,73-75$ & $\begin{array}{l}421 \\
46\end{array}$ & 32.1 \\
\hline $18-4,73-75$ & $\left.\begin{array}{l}46 \\
42\end{array}\right\}$ & 45.5 \\
\hline $18-5,73-75$ & $\left.\begin{array}{l}42 \\
47\end{array}\right\}$ & \\
\hline $18-6,73-75$ & $\begin{array}{l}47) \\
44)\end{array}$ & \\
\hline $\begin{array}{l}19-1,73-75 \\
19-2,73-75\end{array}$ & $\left.\begin{array}{l}44 \\
41\end{array}\right\}$ & 45.7 \\
\hline $19-3,73-75$ & 52 & 70.1 \\
\hline $19-4,73-75$ & $46)$ & \\
\hline $19-5,73-75$ & 52 & 51.3 \\
\hline $19-6,73-75$ & 57 & 51.3 \\
\hline $19-7,73-75$ & 50 & \\
\hline $20-1,73-75$ & 54 & \\
\hline $20-2,73-75$ & 45 & 51 \\
\hline $20-3,73-75$ & $54)$ & \\
\hline $20-4,73-75$ & $43)$ & \\
\hline $20-5,73-75$ & 40 & 46.3 \\
\hline $20-6,73-75$ & 50 & \\
\hline $20-7,73-75$ & 52 & \\
\hline $21-1,73-75$ & 56 & \\
\hline $21-2,73-75$ & 57 & 56 \\
\hline $21-3,73-75$ & 55 & \\
\hline $21-4,73-75$ & 52 & \\
\hline $21-5,73-75$ & 54 & \\
\hline $21-6,73-75$ & 59 & 57.6 \\
\hline $21-7,73-75$ & 59 & \\
\hline $21-8,63-65$ & 64 & \\
\hline $22-1,73-75$ & 72 & \\
\hline $22-2,73-75$ & 72 & 72.7 \\
\hline $22-3,73-75$ & $74)$ & \\
\hline $22-4,73-75$ & $68 \mid$ & \\
\hline $22-5,73-75$ & $68\}$ & 64.7 \\
\hline $22-6,73-75$ & 581 & \\
\hline $23-1,73-75$ & $62)$ & \\
\hline $23-2,73-75$ & $63\}$ & 63.3 \\
\hline $23-3,73-75$ & $65 J$ & \\
\hline $23-4,73-75$ & $61)$ & \\
\hline $23-5,73-75$ & $61\}$ & 62.3 \\
\hline $23-6,73-75$ & $65)$ & \\
\hline $24-1,73-75$ & $65\}$ & 66.5 \\
\hline $24-2,73-75$ & 681 & \\
\hline
\end{tabular}

a "Karbonat Bombe" determinations.

time within this time interval, the bulk accumulation rates of Sites 504 and 505 were higher than the mean equatorial bulk accumulation rates, indicating that there has been a higher primary contribution of remains of planktonic organisms at the east end of the equatorial high-productivity belt than at the west.

Moore et al. (1973) showed that in the greater Panama Basin, a latitudinal band of high biological productivity lying between $4^{\circ} \mathrm{S}$ and $2^{\circ} \mathrm{N}$ and associated with the Peru Current and the equatorial divergence has existed for at least several hundred thousand years. Based on the generally high accumulation rates of Sites 504 and 505 , this band must have existed for the past 5.9 m.y. Since plate tectonics show that the two sites could only have migrated from west to east with respect to a fixed Galapagos melting anomaly (Fig. 11), the sites should have remained within the zone of high primary productivity near the equator throughout their histories. 
Table 10. Composition of coarse fraction samples from Hole 505.

\begin{tabular}{|c|c|c|c|c|c|c|c|c|c|c|c|c|c|c|c|c|c|c|}
\hline Core & Sections & $\begin{array}{c}\text { Fora- } \\
\text { minifers } \\
\text { (whole } \\
\text { tests) }\end{array}$ & $\begin{array}{l}\text { Fora- } \\
\text { minifer } \\
\text { Frag- } \\
\text { ments }\end{array}$ & $\begin{array}{c}\text { Total } \\
\text { Fora- } \\
\text { miniferal } \\
\text { Material }\end{array}$ & $\begin{array}{l}\text { Foraminifer } \\
\text { Fragments } \\
\text { Whole Tests }\end{array}$ & Radiolarians & Diatoms & $\begin{array}{c}\text { Fish } \\
\text { Debris }\end{array}$ & Pellets & $\begin{array}{l}\text { Echinoderm } \\
\text { Spicules }\end{array}$ & $\begin{array}{l}\text { Sponge } \\
\text { Spicules }\end{array}$ & Ostracods & $\begin{array}{l}\text { Volcanic } \\
\text { Glass }\end{array}$ & Quartz & Feldspar & Mica & Pyrite & $\begin{array}{c}\text { Miscel- } \\
\text { laneous } \\
\text { Components }\end{array}$ \\
\hline \multicolumn{19}{|c|}{ Proportion of Coarse Fraction ${ }^{\mathrm{a}}$ Samples (grain \%) } \\
\hline 2 & $1-3$ & 7.8 & 50.1 & 57.9 & 6.4 & 31.3 & 2.4 & 0.8 & 2.6 & 0 & $\mathrm{Tr}$ & 0 & 2.4 & 0 & 0 & 0 & 1.5 & $\operatorname{Tr}$ \\
\hline 2 & $4-5$ & 11.6 & 66 & 77.6 & 5.7 & 18.6 & 1.2 & 0.4 & 0 & 0 & $\mathrm{Tr}$ & 0 & $\mathrm{Tr}$ & 0 & 0 & 0 & 1.2 & $\operatorname{Tr}$ \\
\hline 3 & $1-3$ & 10.9 & 36.7 & 47.6 & 3.4 & 31.6 & 1.5 & 0.7 & 0 & 0 & $\mathrm{Tr}$ & 0 & 15 & 0 & 0 & 0 & 2.2 & 0 \\
\hline 3 & $0-5$ & 7.3 & 24.2 & 31.5 & 3.3 & 58 & 1.7 & 0.6 & 0.7 & 0 & 0 & $\mathrm{Tr}$ & 6.7 & 0 & 0 & 0 & 0.6 & $\operatorname{Tr}$ \\
\hline 4 & $2-3$ & 7.2 & 34.7 & 41.9 & 4.8 & 47.1 & 1.9 & 0.4 & 0.2 & $\mathrm{Tr}$ & $\operatorname{Tr}$ & 0 & 4 & 0 & 0 & $\mathrm{Tr}$ & 3.2 & 2.5 \\
\hline 4 & 4-7 & 8.4 & 47.2 & 55.6 & 5.6 & 23.3 & $\mathrm{Tr}$ & 1.3 & 0 & 0 & $\operatorname{Tr}$ & 0 & 16.5 & 0 & 0 & $\mathrm{Tr}$ & 2.1 & 0 \\
\hline 5 & $1-5$ & 7.7 & 52 & 59.7 & 6.8 & 35.1 & $\operatorname{Tr}$ & 1.1 & 0.1 & $\mathrm{Tr}$ & $\mathrm{Tr}$ & 0 & 2 & 0 & 0 & $\operatorname{Tr}$ & $\operatorname{Tr}$ & 0 \\
\hline 5 & $4-6$ & 7.5 & 39.6 & 47.1 & 5.3 & 45.1 & $\mathrm{Tr}$ & 0.7 & 0 & $\mathrm{Tr}$ & $\mathrm{Tr}$ & 0 & 2.4 & 0 & 0 & $\mathrm{Tr}$ & 2.4 & 1.0 \\
\hline 6 & $1-3$ & 8.2 & 45.8 & 54 & 5.6 & 35.2 & $\mathrm{Tr}$ & 0.7 & 0.6 & 0 & $\mathrm{Tr}$ & 0 & 4.7 & 0 & 0 & $\mathrm{Tr}$ & 4.6 & 7.4 \\
\hline 6 & $4-7$ & 14 & 40.7 & 54.7 & 2.9 & 36.1 & 1.1 & 0.9 & 0.2 & 0 & $\mathrm{Tr}$ & 0 & $\operatorname{Tr}$ & 0 & $\operatorname{Tr}$ & $\operatorname{Tr}$ & 5.8 & 0 \\
\hline 7 & $1-3$ & 3.6 & 43.6 & 47.2 & 12.1 & 45.9 & 3.9 & 0.4 & 0.1 & 0 & $\mathrm{Tr}$ & 0 & $\mathrm{Tr}$ & 0 & $\mathrm{Tr}$ & $\mathrm{Tr}$ & 1.5 & 0 \\
\hline 7 & $4-6$ & 7.9 & 35.7 & 43.6 & 4.5 & 38.3 & 9.8 & 0.6 & 3.1 & $\mathrm{Tr}$ & $\mathrm{Tr}$ & 0 & 1 & 0 & 0 & 0 & 2.9 & $\mathrm{Tr}$ \\
\hline 9 & $1-3$ & 7.7 & 38.2 & 54.9 & 5 & 39 & 8.5 & 0.6 & 0 & 0 & 0 & 0 & $\mathrm{Tr}$ & 0 & 0 & 0 & 4.1 & 1.8 \\
\hline 10 & $1-3$ & 13.7 & 30.8 & 44.5 & 2.2 & 48.9 & $\mathrm{Tr}$ & 0.4 & 0 & $\mathrm{Tr}$ & 0 & 0 & $\mathrm{Tr}$ & 0 & 0 & 0 & 4.9 & $\mathrm{Tr}$ \\
\hline 10 & $4-5$ & 6.1 & 49.7 & 55.8 & 8.1 & 36.7 & $\mathrm{Tr}$ & 0.5 & 0 & $\mathrm{Tr}$ & $\mathrm{Tr}$ & 0 & 1.9 & $\mathrm{Tr}$ & 0 & 0 & 3.4 & $\mathrm{Tr}$ \\
\hline 11 & $1-3$ & 4.6 & 17.4 & 22.1 & 3.8 & 61.8 & $\mathrm{Tr}$ & 0.7 & 0 & $\mathrm{Tr}$ & $\mathrm{Tr}$ & 0 & 11.5 & $\mathrm{Tr}$ & 0 & $\mathrm{Tr}$ & 2.1 & 0 \\
\hline 11 & 4-6 & 5 & 16.1 & 21.1 & 3.2 & 68.2 & $\mathrm{Tr}$ & 1.3 & 0 & 0 & 0 & 0 & 1.5 & 0 & 0 & $\mathrm{Tr}$ & 3 & 4.4 \\
\hline 12 & $1-3$ & 4.6 & 26.4 & 31 & 5.7 & 61.3 & 1.0 & 1.1 & 0.2 & $\mathrm{Tr}$ & $\mathrm{Tr}$ & 0 & $\mathrm{Tr}$ & 0 & 0 & $\mathrm{Tr}$ & 1.9 & $\mathrm{Tr}$ \\
\hline 12 & $0-4$ & 15.5 & 34.3 & 39.8 & 6.2 & 50 & 5.8 & 1.2 & 0.4 & 0 & $\mathrm{Tr}$ & 0 & $\mathrm{Tr}$ & $\mathrm{Tr}$ & 0 & 0 & $\mathrm{Tr}$ & 0 \\
\hline 13 & $1-3$ & 5.8 & 15.2 & 21 & 2.6 & 69.6 & 1.1 & 1.4 & 0.4 & 0 & $\mathrm{Tr}$ & 0 & $\mathrm{Tr}$ & $\mathrm{Tr}$ & 0 & $\mathrm{Tr}$ & 1.8 & 3.3 \\
\hline 13 & $4-6$ & 6.7 & 21.9 & 28.6 & 3.3 & 59.2 & 1 & 0.8 & 0.2 & $\mathrm{Tr}$ & $\mathrm{Tr}$ & 0 & 5.6 & $\mathrm{Tr}$ & 0 & $\mathrm{Tr}$ & 2.1 & $\mathrm{Tr}$ \\
\hline 14 & $1-3$ & 6.6 & 29.3 & 35.9 & 4.4 & 58.8 & $\mathrm{Tr}$ & 0.9 & 0.1 & $\mathrm{Tr}$ & $\mathrm{Tr}$ & 0 & 1.5 & $\mathrm{Tr}$ & 0 & $\mathrm{Tr}$ & 1.3 & $\mathrm{Tr}$ \\
\hline 14 & $4-5$ & 4.6 & 19.5 & 24.1 & 4.2 & 71.8 & $\mathrm{Tr}$ & 0.9 & 0.3 & $\mathrm{Tr}$ & $\mathrm{Tr}$ & 0 & $\mathrm{Tr}$ & 0 & 0 & 0 & 0.9 & $\mathrm{Tr}$ \\
\hline 15 & $2-3$ & 15.3 & 27.7 & 43 & 1.8 & 52.5 & 1 & 0.8 & 0 & $\mathrm{Tr}$ & $\mathrm{Tr}$ & 0 & $\mathrm{Tr}$ & 0 & 0 & 0 & 1.7 & 0 \\
\hline 15 & $4-6$ & 10.1 & 17 & 27.1 & 1.7 & 62.2 & 3.8 & 0.7 & 0.1 & $\mathrm{Tr}$ & 0 & 0 & 1.4 & $\mathrm{Tr}$ & 0 & 0 & 4.1 & 0 \\
\hline 17 & $1-3$ & 8.2 & 17.6 & 25.8 & 2.1 & 66.3 & 2.4 & 1.3 & 0.1 & $\mathrm{Tr}$ & $\mathrm{Tr}$ & 0 & $\mathrm{Tr}$ & $\mathrm{Tr}$ & 0 & $\mathrm{Tr}$ & 2.7 & $\mathrm{Tr}$ \\
\hline 17 & $4-8$ & 13 & 23.7 & 36.7 & 1.8 & 52.9 & 1 & 1.1 & 0.6 & $\mathrm{Tr}$ & $\mathrm{Tr}$ & 0 & 2.8 & $\mathrm{Tr}$ & $\mathrm{Tr}$ & $\mathrm{Tr}$ & 3.5 & $\mathrm{Tr}$ \\
\hline 18 & $1-3$ & 10.4 & 15.5 & 27.9 & 1.7 & 59.3 & $\mathrm{Tr}$ & 1.4 & 0 & $\mathrm{Tr}$ & $\mathrm{Tr}$ & 0 & 7.1 & $\mathrm{Tr}$ & 0 & 0 & 3.2 & 0 \\
\hline 18 & $4-6$ & 6.6 & 21.6 & 28.2 & 3.3 & 52 & 1.4 & 0.6 & 0.5 & $\mathrm{Tr}$ & $\mathrm{Tr}$ & 0 & 13.4 & 0 & 0 & 0 & 3.1 & $\mathrm{Tr}$ \\
\hline 19 & $1-3$ & 10.2 & 20.3 & 30.5 & 2 & 60.2 & $\mathrm{Tr}$ & 0.7 & 0 & $\mathrm{Tr}$ & $\mathrm{Tr}$ & $\mathrm{Tr}$ & 2.5 & $\mathrm{Tr}$ & $\mathrm{Tr}$ & $\mathrm{Tr}$ & 4.4 & 0 \\
\hline 19 & $4-7$ & 11.1 & 19 & 30.1 & 1.7 & 63.2 & $\mathrm{Tr}$ & 0.9 & 0 & $\mathrm{Tr}$ & $\mathrm{Tr}$ & 0 & 2.2 & 0 & $\mathrm{Tr}$ & $\mathrm{Tr}$ & 1.4 & 0 \\
\hline 20 & $1-3$ & 10.9 & 32.2 & 43.1 & 3 & 47 & 2.6 & 0.8 & 0 & $\mathrm{Tr}$ & $\mathrm{Tr}$ & 0 & 2.2 & 0 & $\mathrm{Tr}$ & $\mathrm{Tr}$ & 1.9 & 1.6 \\
\hline 20 & $4-7$ & 6.4 & 30.3 & 36.7 & 4.7 & 53 & 4.4 & 0.7 & 0 & $\mathrm{Tr}$ & $\mathrm{Tr}$ & 0 & 2.5 & 0 & 0 & $\mathrm{Tr}$ & 1.5 & $\mathrm{Tr}$ \\
\hline 21 & $1-3$ & 11.9 & 28.9 & 40.8 & 2.4 & 53 & 1.8 & 0.6 & 0 & $\mathrm{Tr}$ & $\mathrm{Tr}$ & 0 & 1.9 & 0 & 0 & $\mathrm{Tr}$ & 1.3 & 0 \\
\hline 21 & $4-7$ & 9.9 & 30.3 & 40.2 & 3.1 & 52.5 & 2.2 & 0.7 & 0 & $\mathrm{Tr}$ & $\mathrm{Tr}$ & 0 & 2.0 & 0 & 0 & $\mathrm{Tr}$ & 1.5 & $\mathrm{Tr}$ \\
\hline 22 & $1-3$ & 10 & 26.6 & 56.6 & 4.7 & 36.4 & $\mathrm{Tr}$ & 1.4 & 0 & $\mathrm{Tr}$ & $\mathrm{Tr}$ & 0 & 2.6 & 0 & 1.2 & $\mathrm{Tr}$ & $\mathrm{Tr}$ & 0 \\
\hline 22 & 4-6 & 6.7 & 30.7 & 37.4 & 4.6 & 52.2 & 1.8 & 1.3 & 0.4 & $\mathrm{Tr}$ & 0 & 0 & 3 & 0 & 1.2 & 0 & 2.2 & $\mathrm{Tr}$ \\
\hline 23 & $1-3$ & 9.2 & 35 & 44.2 & 3.8 & 46 & $\mathrm{Tr}$ & 1.1 & 0.1 & $\mathrm{Tr}$ & $\mathrm{Tr}$ & 0 & 4.1 & 0 & 2 & 0 & 1.1 & $\mathrm{Tr}$ \\
\hline 23 & $4-6$ & 5.2 & 39.6 & 44.8 & 7.6 & 42.5 & 3.3 & 1.7 & 0 & $\mathrm{Tr}$ & $\mathrm{Tr}$ & 0 & 3.8 & 0 & 1.3 & 0 & 1.3 & $\mathrm{Tr}$ \\
\hline 24 & $1-2$ & 5.4 & 40.3 & 45.7 & 7.5 & 35.6 & $\mathrm{Tr}$ & 0.8 & 0 & $\mathrm{Tr}$ & $\mathrm{Tr}$ & 0 & 9.5 & 0 & 2.8 & 0 & 4.4 & $\mathrm{Tr}$ \\
\hline
\end{tabular}




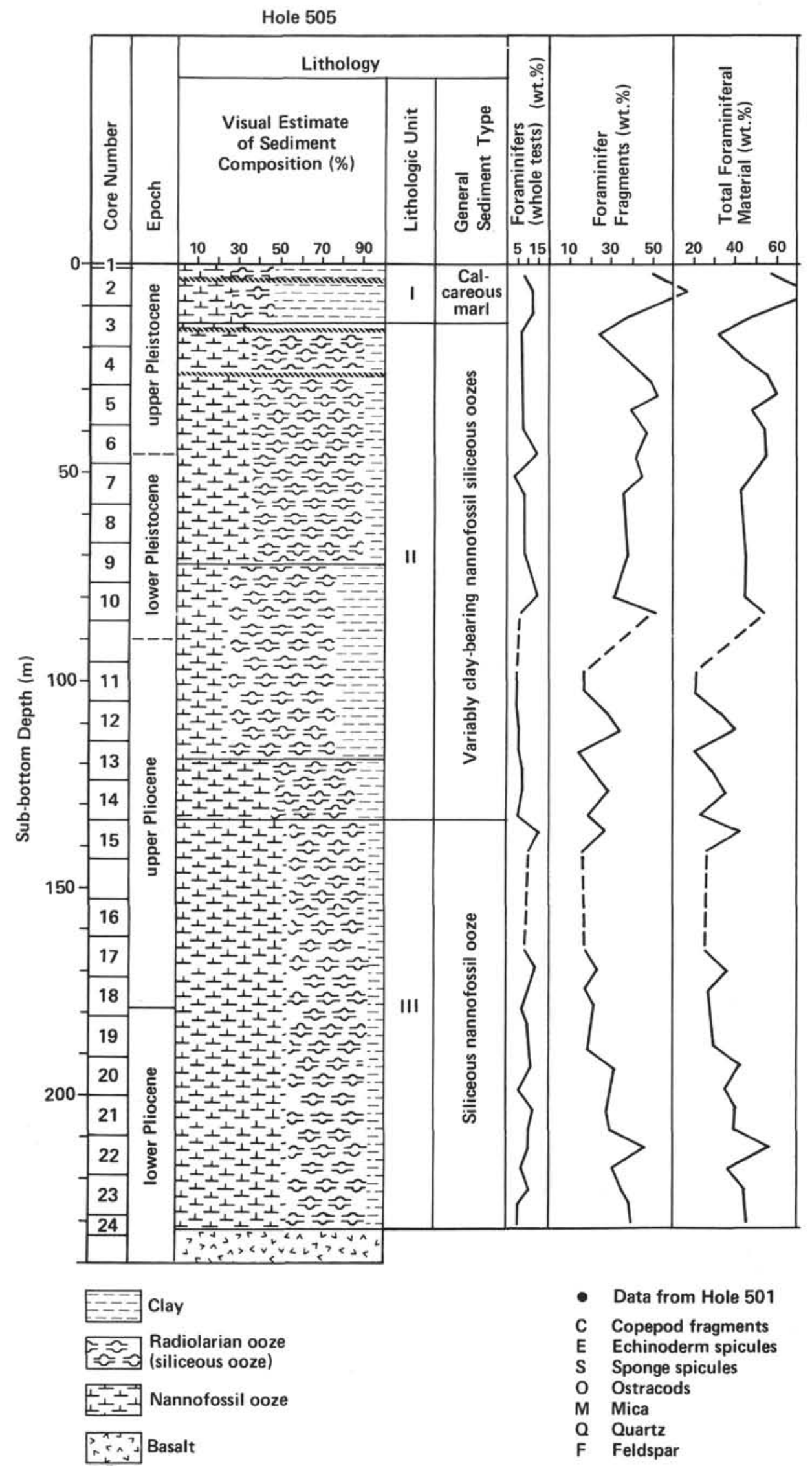

Figure 9. Coarse fraction data for the sediments of Hole 505. 


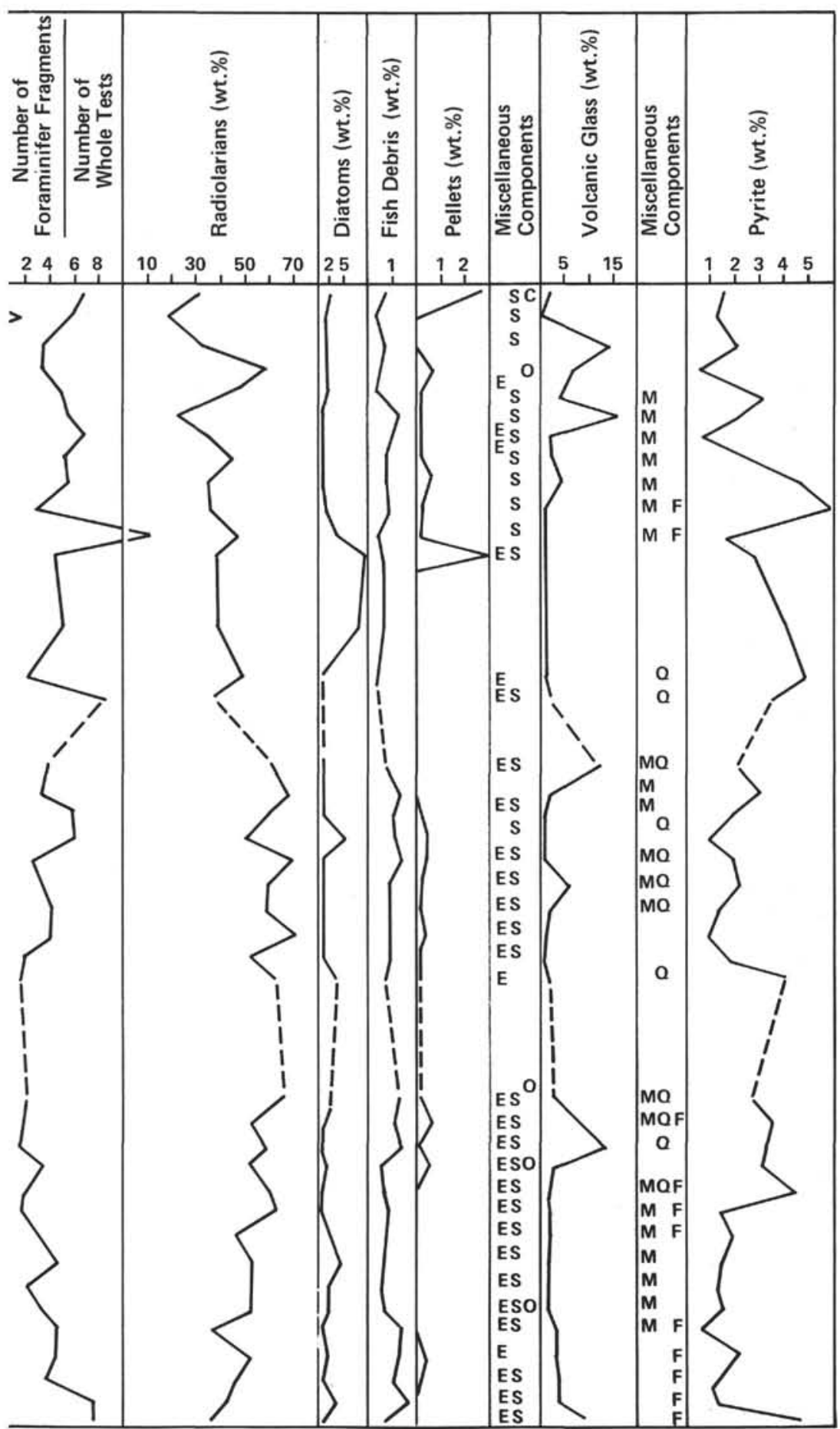

Figure 9. (Continued). 

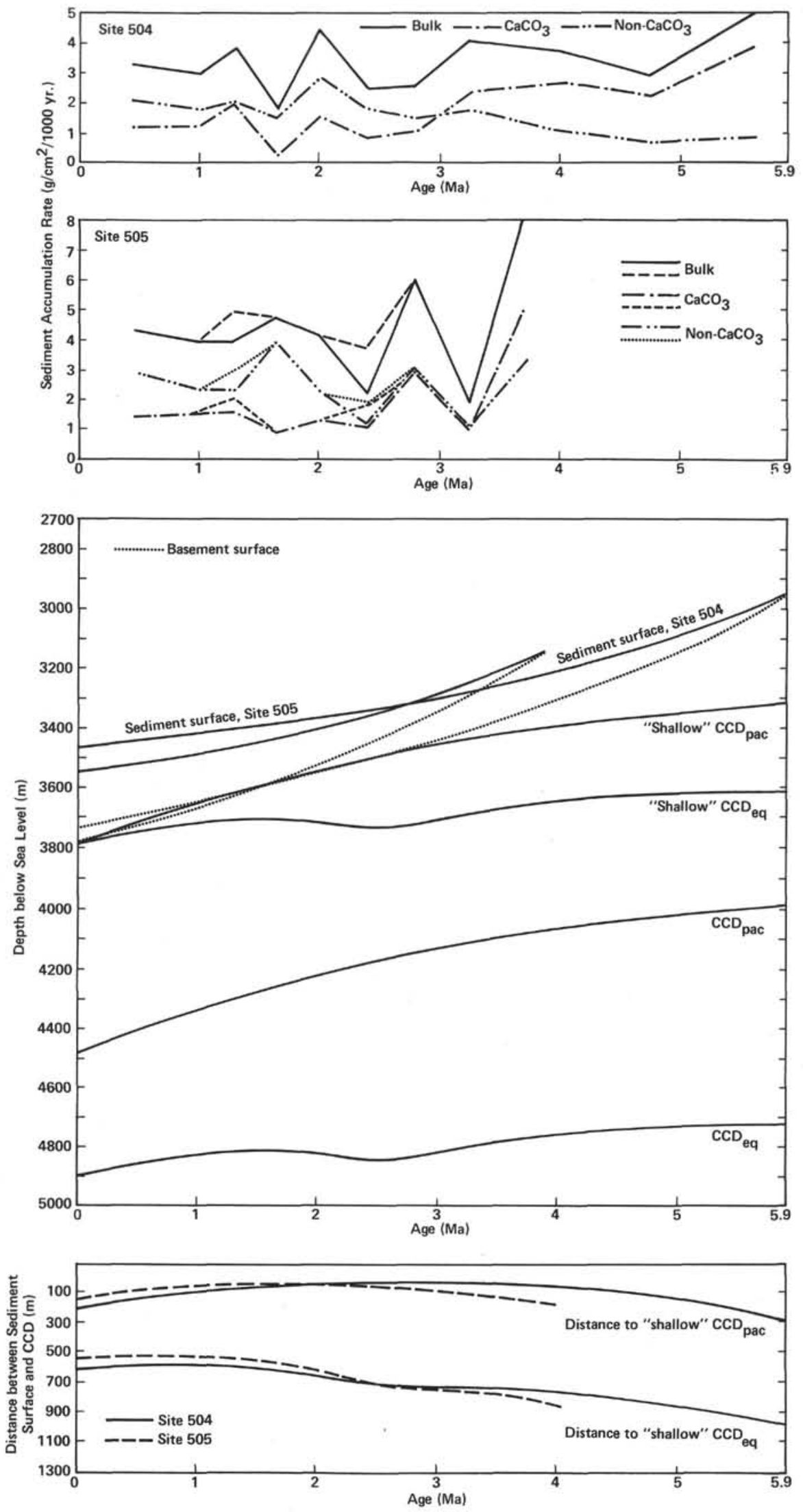

Figure 10. Variation with time of Site 504 and 505 accumulation rates, subsidence curves, and distances between sediment and basement surfaces and CCD levels. $C C D_{p a c}=$ Pacific CCD; $\mathrm{CCD}_{\mathrm{eq}}=$ equatorial CCD, from van Andel et al. (1975). 
Table 11. Accumulation rates for Hole 504.

\begin{tabular}{ccccccccc}
\hline $\begin{array}{c}\text { Time } \\
\text { Interval } \\
(\mathrm{m} . \mathrm{y} .)\end{array}$ & $\begin{array}{c}\Delta \mathrm{T} \\
(\mathrm{m} . \mathrm{y} .)\end{array}$ & $\begin{array}{c}\text { Sediment } \\
\text { Thickness } \\
(\mathrm{m})\end{array}$ & $\begin{array}{c}\text { Wet Bulk } \\
\text { Density } \\
\left(\mathrm{g} / \mathrm{cm}^{3}\right)\end{array}$ & Porosity & $\begin{array}{c}\text { Dry Bulk } \\
\text { Density } \\
\left(\mathrm{g} / \mathrm{cm}^{3}\right)\end{array}$ & $\begin{array}{c}\text { Bulk } \\
\text { Accumulation } \\
\text { Ratea } \\
\left(\mathrm{g} / \mathrm{cm}^{2} / 10^{3} \mathrm{yr} .\right)\end{array}$ & $\begin{array}{c}\text { Mean } \\
\mathrm{CaCO}_{3} \\
(\%)\end{array}$ & $\begin{array}{c}\mathrm{CaCO}_{3} \\
\text { Accumulation } \\
\text { Rate } \\
\left(\mathrm{g} / \mathrm{cm}^{2} / 10^{3} \mathrm{yr}\right)\end{array}$ \\
\hline $0-0.9$ & 0.9 & 40 & 1.32 & 0.8 & 0.73 & 3.24 & 36.7 & 1.19 \\
$0.9-1.1$ & 0.2 & 8 & 1.34 & 0.79 & 0.74 & 2.96 & 40.5 & 1.21 \\
$1.1-1.5$ & 0.4 & 20 & 1.37 & 0.76 & 0.77 & 3.85 & 48 & 1.84 \\
$1.5-1.8$ & 0.3 & 8 & 1.24 & 0.84 & 0.67 & 1.79 & 15.5 & 0.28 \\
$1.8-2.2$ & 0.4 & 25 & 1.29 & 0.8 & 0.71 & 4.44 & 35.2 & 1.55 \\
$2.2-2.6$ & 0.4 & 14 & 1.33 & 0.8 & 0.71 & 2.48 & 32.7 & 0.81 \\
$2.6-3.0$ & 0.4 & 14 & 1.33 & 0.8 & 0.73 & 2.55 & 42.7 & 1.09 \\
$3.0-3.5$ & 0.5 & 27 & 1.35 & 0.75 & 0.76 & 4.10 & 56.5 & 2.34 \\
$3.5-4.5$ & 1.0 & 42 & 1.48 & 0.66 & 0.89 & 3.74 & 71.2 & 2.66 \\
$4.5-5.0$ & 0.5 & 17 & 1.46 & 0.68 & 0.86 & 2.92 & 78 & 2.27 \\
$5.0-5.9$ & 0.9 & 55 & & & & & & \\
\hline
\end{tabular}
a Bulk accumulation rate $=$ Sediment accumulation rate $\frac{\text { Thickness }}{\Delta \mathrm{T}} \times$ Dry bulk density. $\mathrm{CaCO}_{3}-\mathrm{Accum}_{\text {alation }}$
rate $=$ Bulk accumulation $\times \% \mathrm{CaCO}_{3} / 100$.

Table 12. Accumulation rates for Hole 505.

\begin{tabular}{|c|c|c|c|c|c|c|c|c|}
\hline $\begin{array}{l}\text { Time Interval } \\
\text { (m.y.) }\end{array}$ & $\underset{(\mathrm{m} . \mathrm{y} .)}{\Delta \mathrm{T}}$ & $\begin{array}{l}\text { Sediment } \\
\text { Thickness } \\
\text { (m) }\end{array}$ & $\begin{array}{l}\text { Wet Bulk } \\
\text { Density } \\
\left(\mathrm{g} / \mathrm{cm}^{3}\right)\end{array}$ & Porosity & $\begin{array}{c}\text { Dry Bulk } \\
\text { Density } \\
\left(\mathrm{g} / \mathrm{cm}^{3}\right)\end{array}$ & $\begin{array}{c}\text { Bulk } \\
\text { Accumulation } \\
\text { Rate } \\
\left(\mathrm{g} / \mathrm{cm}^{2} / 10^{3} \mathrm{yr} \text {. }\right)\end{array}$ & $\begin{array}{c}\text { Mean } \\
\mathrm{CaCO}_{3} \\
(\%)\end{array}$ & $\begin{array}{c}\mathrm{CaCO}_{3} \\
\text { Accumulation } \\
\text { Rate } \\
\left(\mathrm{g} / \mathrm{cm}^{2} / 10^{3} \mathrm{yr} .\right)\end{array}$ \\
\hline $0-0.9$ & 0.9 & 57.5 & 1.27 & 0.84 & 0.68 & 4.34 & 33.1 & 1.43 \\
\hline $0.9-1.1$ & 0.2 & 10.5 & 1.35 & 0.8 & 0.74 & 3.89 & 40 & 1.56 \\
\hline $1.1-1.5$ & 0.4 & $\begin{array}{l}22 \\
(27.5)^{\mathrm{a}}\end{array}$ & 1.32 & 0.82 & 0.72 & $\begin{array}{c}3.96 \\
(4.99)\end{array}$ & 40.8 & $\begin{array}{c}1.62 \\
(2.02)\end{array}$ \\
\hline $1.5-1.8$ & 0.3 & 21.5 & 1.24 & 0.85 & 0.66 & 4.73 & 18.3 & 0.85 \\
\hline $1.8-2.2$ & 0.4 & 20.5 & 1.30 & 0.82 & 0.71 & 3.63 & 36.8 & 1.34 \\
\hline $2.2-2.6$ & 0.4 & $\begin{array}{l}15 \\
(20.5)\end{array}$ & 1.34 & 0.80 & 0.74 & $\begin{array}{l}2.22 \\
(3.79)\end{array}$ & 48 & $\begin{array}{c}1.07 \\
(1.82)\end{array}$ \\
\hline $2.6-3.0$ & 0.4 & 32 & 1.35 & 0.79 & 0.75 & 6.00 & 48.2 & 2.88 \\
\hline $3.0-3.5$ & 0.5 & 13 & 1.39 & 0.77 & 0.78 & 2.03 & 47.6 & 0.97 \\
\hline $3.5-3.9$ & 0.4 & 40 & 1.46 & 0.73 & 0.83 & 8.3 & 61.4 & 5.06 \\
\hline
\end{tabular}

a Numbers in parentheses are alternatives for washed intervals.

The $\mathrm{CaCO}_{3}$ accumulation rates have generally decreased since the onset of sediment accumulation at both sites, and they became smaller than the non- $\mathrm{CaCO}_{3}$ accumulation rates at about $3 \mathrm{Ma}$. They reached minima at the two sites about $2 \mathrm{Ma}$ but have increased somewhat since. These trends are obviously related to the subsidence history of the sites and fluctuations in the calcite compensation depth in the Panama Basin.

After the creation of the basement at the ancient Costa Rica Rift, both sites subsided as a result of the cooling of the lithosphere. The subsidence curves, which were constructed by using the empirical formula for fast-spreading ridges of LePichon et al. (1976), show that the present depths of basement (corrected for sediment load) are deeper at both sites than an ideal subsidence curve that starts at 2750 meters and follows the empirical formula would suggest. The present Costa Rica Rift is about $\mathbf{3 0 0 0}$ meters deep (Lonsdale and Klitgord, 1978), and it probably was at about this depth when Sites 505 and 504 were at the rift axis 3.9 and 5.9 $\mathrm{Ma}$, respectively. The basement of Site 505, however, is deeper than that of Site 504, although it is covered by sediment that has ponded to nearly equal thickness. There must have been a very rapid local subsidence of the area immediately around the site at the time of the formation of the graben in which the site is located. This was probably shortly after the removal of the site by spreading from the vicinity of the active rift. Since that time, subsidence rates for the two sites have probably followed more ideal subsidence curves.

A unified history of the calcite compensation depth (CCD) for the Panama Basin has not yet been established. Therefore it is difficult to relate the fluctuations in accumulation rates to the CCD and the history of subsidence. Moore et al. (1973) determined that the present CCD in the Panama Basin is at about 3800 meters. This is much shallower than the 4500 -meter and 4700-meter CCD's found in the south and equatorial Pacific (van Andel et al., 1975). However, if a CCD curve is applied that starts at $\mathbf{3 8 0 0}$ meters and runs parallel to the Pacific CCD curve as derived by van Andel et al. (1975), the distances between the sediment surfaces of the sites and the CCD were least between 3.4 and $1.3 \mathrm{~m} . \mathrm{y}$. ago (Fig. 10). Within this time interval the major events in the accumulation rate curves occur (the rate of non- $\mathrm{CaCO}_{3}$ accumulation exceeds that of $\mathrm{CaCO}_{3}$ accumulation, and there are major drops in the bulk accumulation rate). This would not have been so if a "shallow" equatorial type of CCD (starting at $3800 \mathrm{~m}$ ) had existed (Fig. 10). The presence of a "shallow" Pacific CCD matches best the inferred history of carbonate accumulation and dissolution features of Holes 504 and 505.

More deep sampling, however, will be needed to define the CCD in the Panama Basin. The histories of our two sites, though generally similar, cannot be related to 


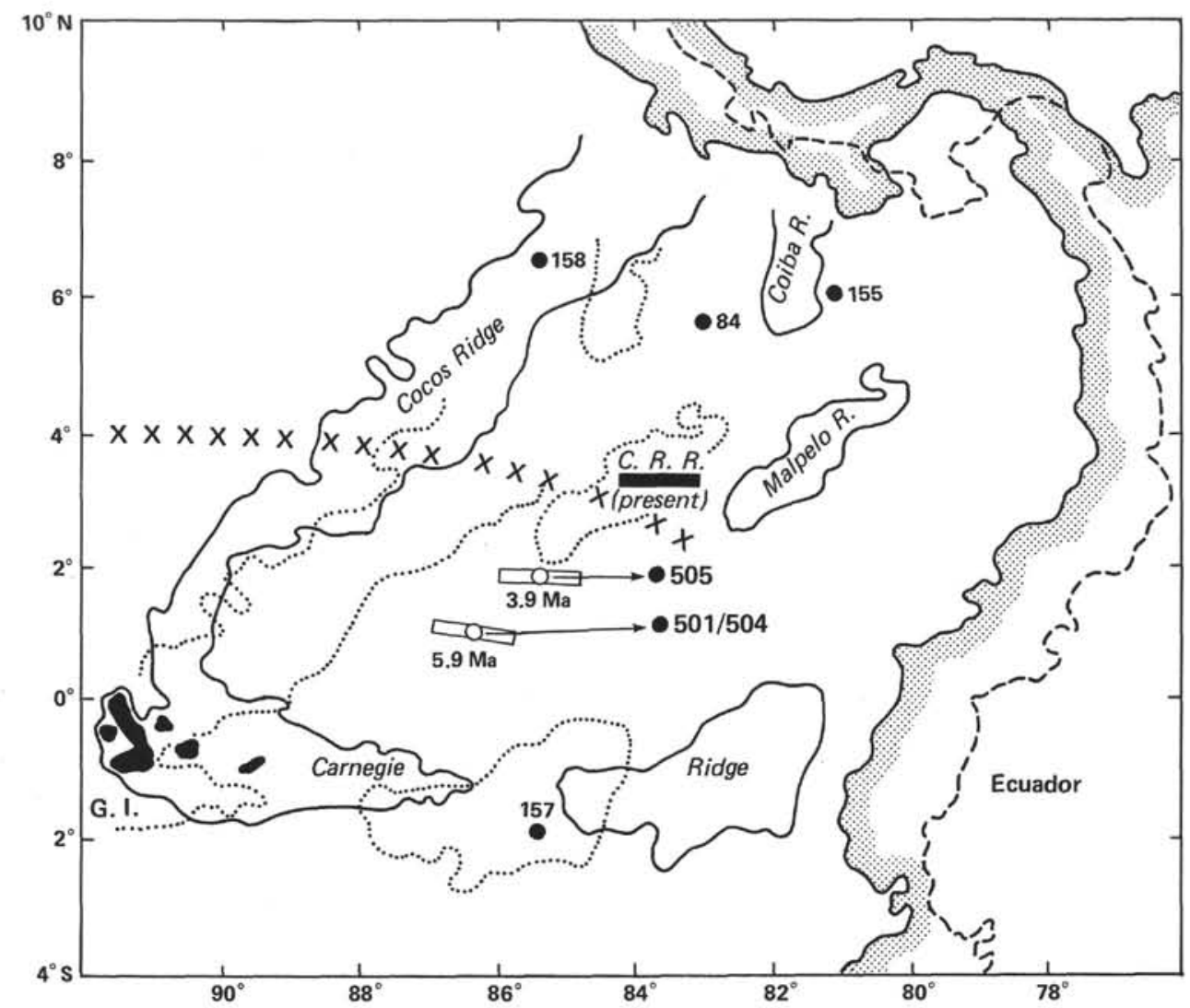

Figure 11. Migration of the Costa Rica Rift (C.R.R.) and of Sites 504 and 505 (arrows) since their basement formation 5.9 and $3.9 \mathrm{Ma}$, respectively. Aseismic ridges are delineated by the approximate 2000 $\mathrm{m}$ contour (heavy lines: present situation; dotted lines: $6 \mathrm{Ma}$ ). The dashed line is the approximate mainland coast at $6 \mathrm{Ma}$. Finite rotation reconstruction after Hey (1977). G. L., Galapagos Islands. xxxx, approximate boundary between Peru Current and the equatorial countercurrent (Defant, 1961). Heavy dots are DSDP sites with numbers as shown. Open circles show site locations at the time their basement was forming. Boxes around open dots are past positions of the Costa Rica Rift (filled box is the present position) when Sites 505 and 504 were at the rift axis, 3.9 and $6.9 \mathrm{Ma}$, respectively.

the curves in Figure 10 in quite the same ways. The higher accumulation rates at Site 505 and the lack of correspondence of the peaks and troughs in the accumulation rate curves for Sites 504 and 505 suggests that other factors complicated the depositional histories of the sites. The higher accumulation rates at Site 505 are very likely a consequence of the position of this site in a graben, which allowed additional sediment to be winnowed in from surrounding basement highs.

Of our two sites, then, Site 504 is the more likely to reflect genuine fluctuations in the CCD and surface-water productivity. The basement is unusually flat, with no more than 20 to 30 meters of relief for 20 to $30 \mathrm{~km}$ both north and south of the site. The thickness of the sediment is quite uniform for this entire distance, although it thickens slightly to the south, where the crust is older. However, the gross patterns of the accumulation rates at Sites 504 and 505 are similar. For example, the accumulation rates for both sites display a pronounced dip between 2.2 and $2.6 \mathrm{Ma}$. The lithologies of the corresponding intervals are very similar at the two sites (i.e., they are clay rich). Even if one places the topmost occurrence of $N$. jouseae at the base of the lower uncored interval of Site 505, a dip in the accumulation rate remains (Fig. 10), although it is less pronounced.

At these times, if the CCD is assumed to be of the "shallow" Pacific type, the CCD is very close to the sediment surfaces of both sites. The corrosion of foraminifers at sub-bottom depths between 105 and 120 meters at Site 504, the low abundance of foraminifers at both sites (Figs. 3, 4, 8, and 9), and the relatively high percentages of fish debris in the coarse fraction indicate considerable calcite dissolution. However, carbonate dissolution alone does not seem to be responsible for the reduction in accumulation rates during the late Pliocene at both sites.

Earlier it was mentioned that bulk chemical compositions indicated that the proportion of biogenic $\mathrm{SiO}_{2}$ was highest in late Pliocene sediments (Subunits Ib and Ic, Fig. 7). This increase occurred at the expense of both $\mathrm{CaCO}_{3}$ and pelagic clay. A comparison of Figure 7 with the accumulation rate curves in Figure 10 makes it clear that there was a considerable increase in the precipitation of biogenic silica at these times and that the biogenic fraction of the Hole 504 sediments increased despite the reduction in $\mathrm{CaCO}_{3}$ accumulation rates. This is 
indicated by Figure 7, which is based on individual samples, more clearly than by Figure 10 , which is based on time-slice averages.

It is well known that carbonate deposition is considerably affected by fluctuations in the calcite compensation depth, whereas opal, despite evidence of dissolution in the water column, has no corresponding compensation depth (Heath, 1974). The CCD also may shoal beneath regions of high productivity (e.g. Berger, 1970 and 1973) as a response to the higher productivity of calcareous microorganisms in surface waters, particularly if there is an upwelling of the cold, corrosive, oxygendepleted bottom waters that supply nutrients to the surface waters. In other cases, such as the equatorial Pacific west of the Panama Basin, the CCD is deeper beneath highly productive surface waters, but this could be because deeper waters there are not so corrosive. Thus, although the equatorial Pacific CCD is now and has long been deeper than the standard Pacific CCD west of the Panama Basin (van Andel et al., 1975), at the eastern end of the equatorial belt the CCD may well have shoaled considerably in response to the intensification of coldwater upwelling along the South American coast. This would induce high surface productivity but also produce a shallower CCD. The only indication of high surface productivity would then be an increase in the rate of accumulation of biogenic $\mathrm{SiO}_{2}$ and perhaps of fish debris. The carbonate fraction would be reduced, and what was left of it would show major signs of dissolution. The situation may have been quite different to the west beneath the equatorial belt, even at the same time. We see no need for carbonate accumulation rates or preservation at Site 504 to match those of other high productivity areas at the same times. We note that low $\mathrm{CaCO}_{3} \mathrm{ac}$ cumulation rates in the equatorial belt to the west corresponded to a cold period in the Miocene but that this is not the case today (Moore et al., 1982). We see a situation similar to that of the Miocene only in the upper Pliocene sediments of Holes 504 and 505. However, we do not suggest that this was a global effect.

There is some evidence for cold water in the form of climatic indicators in the Hole 504 sediments. The low abundance of foraminifers of the Globorotalia menardii group and common occurrences of Globigerina bulloides together with other "low-temperature" foraminifers in some of the cores of Subunits Ib and Ic (Hole 504, Cores 18,31 , and 22) indicate a cool period. This is very likely the same late Pliocene $(2-2.3 \mathrm{Ma})$ glacial maximum described by Keigwin (1979), who worked with the ${ }^{18} \mathrm{O}$ content of benthic foraminifers at nearby Site 157 , and Shackleton and Hall (this volume), who also worked with the Hole 504 sediments. The existence of a cool period is in accordance with the glaciation of the Northern Hemisphere between 2.8 and $3.3 \mathrm{Ma}$, which induced a global cooling (Shackleton and Opdyke, 1977).

We therefore speculate that this climatic deterioration caused either an intensification of surface productivity over the Panama Basin or a shift in the locus of the most intense productivity closer to Site 504 in the late Pliocene. Differences in the accumulation rates between Sites 504 and 505 therefore could reflect not only the effects of redeposition at Site 505 but a steep and rapidly varying calcite compensation surface between the sites. For example, after the late-Pliocene low in accumulation rate, the bulk accumulation rate of Site 504 shows another marked drop at about the Plio-Pleistocene boundary (Fig. 10), whereas that of Site 505 continues to increase. However, even the increase at Site 505 was inhibited. The sediments at both sites show low $\mathrm{CaCO}_{3}$ contents, high clay abundances, and poor fossil preservation in the corresponding intervals, characteristics that suggest another cooling period. The foraminifer association in Core 13 of Hole 504 also indicates a cool surface water temperature.

From about $1 \mathrm{Ma}$ to the present the accumulation rate curves and lithologies of the two sites are similar. However, the accumulation rates at Site 505 are about $20 \%$ higher because of the graben position of the site. At both sites a minor drop at about $1 \mathrm{Ma}$ may indicate an early stage of late Pleistocene cycles in deposition related to glaciation (Keigwin, 1979). The pronounced fluctuations in the bulk composition and the composition of the coarse fraction and the frequent color changes at both sites may reflect these climatic cycles. In addition, the increased fragmentation of foraminifers in the coarse fractions of both sites indicates a slight shoaling of the CCD.

The early accumulation rate history of the two sites differs markedly. The strong dip in the Site 505 curve at about 3.2 Ma may be the result of the temporary exposure of the site to the relatively warm and weakly saline equatorial countercurrent, with its reduced biological productivity, at a time when Site 504 remained in the high productivity regime. Or it may mark a time of graben formation and rapid local subsidence.

At Site 504, the high accumulation rates between 5.9 and $5 \mathrm{Ma}$ indicate high primary productivity that ceased shortly after the Miocene. Sancetta (this volume) proposes a major shift in the pattern of productivity and upwelling because of a sharp decrease in the abundance of diatoms of the Thalassionema group. A shift is also indicated by the reduction in the total biogenic fraction in Figure 7 after the late Miocene. Apart from this, however, the decrease of the total foraminiferal material in the coarse fraction and the bulk composition and the signs of corrosion on foraminifers are not clear evidence for other climatic changes or fluctuations in the CCD at these times.

In summary, climatic events and the distance between the sediment surface and the CCD are probably responsible for changes in accumulation rates, particularly at Site 504, where local redeposition was probably minor. The history of bottom water circulation is a probable complicating factor. Large volumes of cold bottom waters, which are corrosive to biogenic carbonate skeletal debris, enter the Panama Basin almost exclusively via the Carnegie Passage (the trench between Ecuador and the Carnegie Ridge; Lonsdale, 1977). The rate of supply of these bottom waters, and therefore their residence time in the Panama Basin, is rigorously controlled by the heating of bottom waters along the Galapagos Spreading Center, the advective circulation of these heat- 
ed waters upward, and the sill depth and width of passage at the trench, which allows an influx of cold water to replace water heated at the spreading axis (Lonsdale and Klitgord, 1978). Clearly, if the sill depth has shoaled or the passage has narrowed, the residence time of bottom waters in the Panama Basin could have increased. The mixing of cold bottom water with warmer intermediate water should have been more complete, and warmer waters should have covered a greater proportion of the floor of the Panama Basin than in the past. This would have caused an effective local increase in the depth of the CCD. A sequence of events like this may explain the slight Pleistocene increase in the sediment accumulation rates, inasmuch as Lonsdale and Klitgord (1978) believe that the Carnegie Ridge has only recently reached the trench, constricting the Carnegie Passage and raising sill depths.

Another factor potentially complicating the reconstruction of depositional conditions in the Panama Ba$\sin$ is the closure of the Isthmus of Panama. Keigwin (1978) believes that until about 3.1 Ma there was a surface water communication between the Atlantic and $\mathrm{Pa}$ cific. The complete closure of the Isthmus may have influenced both the biological productivity of the Panama Basin and the circulation of water at every depth. It is difficult to trace the sequence of events from the few data available, however.

\section{Diagenesis of Sediments at Sites 504 and 505}

The lithologic unit boundaries at Site 504 are diagenetic boundaries. The ooze-chalk transition is marked by sudden changes in porosity, shear strength, and thermal conductivity (Wilkens and Langseth, this volume). The calcareous fossils, particularly the foraminifers, are intensely fragmented in the chalks (see the distribution of unspecified carbonate as well as of foraminifer fragments in Figs. 3 and 4), a characteristic that is typical of an early stage of diagenetic calcite dissolution (Schlanger and Douglas, 1974). Strongly corroded foraminifers occur from 168.40 meters sub-bottom downward, and thick calcitic overgrowths on Discoasters occur below 190 meters sub-bottom (Fig. 12). Thus, calcite dissolution and reprecipitation have occurred. A strong increase in the percentage of unspecified carbonate occurs with increasing depth and coincides with the increase in the occurrence of corroded foraminifers and overgrown Discoasters. This is probably a result of intensified calcite dissolution, leading to fragmentation into still smaller particles. These particles are easily confused optically with calcareous nannofossil debris and therefore were probably counted as calcareous nannofossils. The occurrence of overgrowths on Discoasters as well as their thickness increase with depth. The highest degree of calcitic overgrowth occurs within the chalks of Lithologic Unit III.

The limestones of Lithologic Unit III represent the final stage of carbonate mobilization and cementation. The vertical compaction of the nannofossil chalk and limestone resulting from the diagenesis of this unit was intense, as can be judged from compressed Zoophycos burrows (Plate 1) and collapsed foraminifer chambers.
Comparison of the undeformed Zoophycos burrows of Lithologic Unit I, which have average diameters of around $1 \mathrm{~cm}$, and the compressed burrows of Lithologic Unit III, which have diameters of about $2 \mathrm{~mm}$, suggests a vertical compaction of strata of about $80 \%$. However, the presence of many open calcitic foraminifer chambers within the limestones show that carbonate mobilization and cementation were not complete.

Silica was mobilized within the sediments of Lithologic Unit III in addition to the carbonate, as indicated by the occurrence of porcellanites, chert, and opal-CT lepispheres and the presence of chalcedony/quartz within foraminifer chambers (Plate 2, Figs. 3 and 4). The various diagenetic effects within the interbedded chalk, limestone, and chert beds of Site 504 are described in detail by Hein et al. (this volume).

The solid pyrite layer at 231.30 meters sub-bottom, near the top of Lithologic Unit III, may be the result of the diagenetic transformation of burrow- and fossil-filling spheroidal and framboidal pyrite. This pyrite, which consisted originally of small pyrite octahedra (Plate 3, Fig. 3), was transformed into large $(>100 \mu \mathrm{m})$ cubic pyrite crystals (Plate 3, Figs. 4-9).

Though considerably deformed by compaction, some burrow halos also occur in Lithologic Unit III. Before compaction they were obviously of the same type as the abundant halos in Lithologic Unit II, where they probably indicate an early diagenetic mobilization of manganese (see the discussion of Site 504 sedimentary structures).

The cherts and cherty limestones appear abruptly, without transition. There were no gradual changes in the form of the dissolution of siliceous fossil remains in the siliceous nannofossil chalk (Lithologic Unit II). No opal-CT can be detected either visually or by means of X-ray diffraction techniques in Lithologic Unit II (Beiersdorf and Rösch, this volume).

Hein and Yeh (this volume) argue that the high temperatures near the base of the sediment sequence at Site 504 are responsible for the silicification process. In sediments this young (Pliocene/Miocene), the opal-A/opalCT boundary in carbonate facies that undergo average deep-sea heat flow conditions occurs only below a burial depth of 400 meters (Riech and von Rad, 1979). Therefore, the silicification process at Site 504 must have been accelerated by increased heat flow or other factors. The average opal-CT formation temperatures cited in the literature are 25 to $50^{\circ} \mathrm{C}$, well within the range of the temperatures at the base of the sediments at Site 504 (which reached $\approx 50^{\circ} \mathrm{C}$; Becker et al., this volume). We therefore presume that the sharp increase in the rate of transformation of opal-A to opal-CT and thence to quartz at Site 504 results mainly from the abnormally high in situ temperatures. The televiewer experiment (Zoback and Anderson, this volume) revealed that the chert and silicified limestones are concentrated along bedding planes. This observation was confirmed by the recovery of pieces of chert that were flat in shape (Plate 2, Fig. 1).

At Site 505, in contrast, there is no chert and the temperatures in the deepest sediments are very low $\left(\approx 9^{\circ} \mathrm{C}\right.$; Site 505 chapter, this volume). At Site 504, the ooze- 


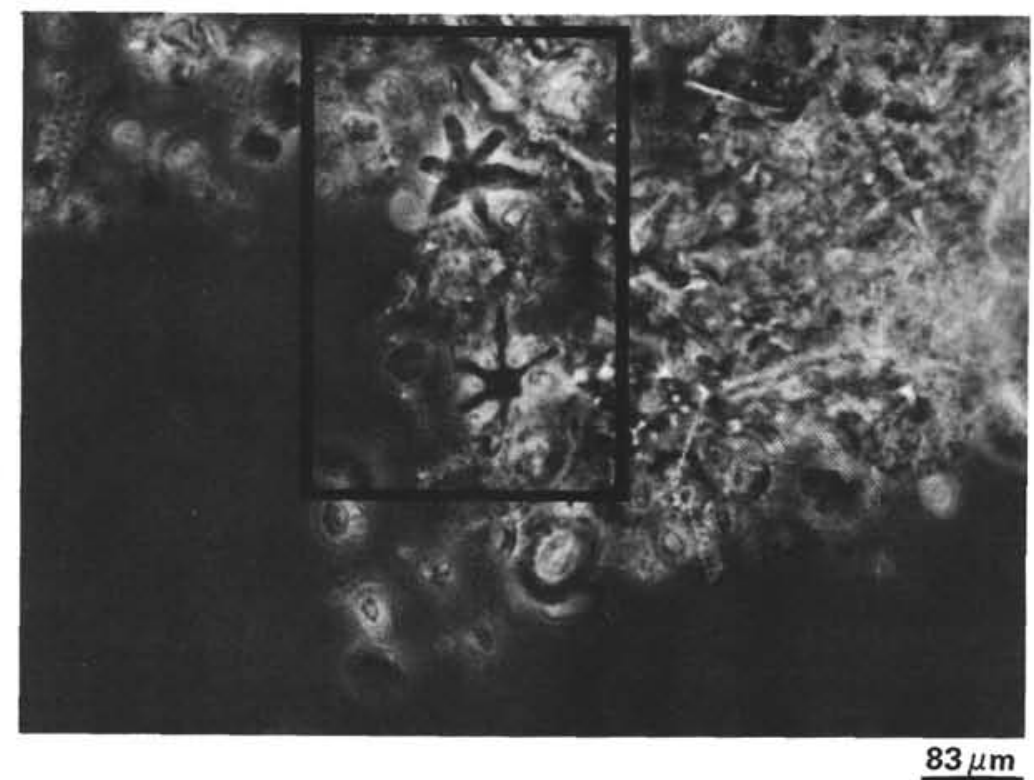

Figure 12. Phase-contrast microphotograph showing calcitic overgrowth on Discoasters in siliceous nannofossil chalk of Site 504. Sample 504-42-1 (106 cm).

chalk transition occurs rather abruptly at a depth of about 130 meters sub-bottom; at Site 505, the transition is considerably deeper $(\approx 210 \mathrm{~m}$ sub-bottom). It is also more gradational, with the sediments becoming firmer and the burrow halos becoming more abundant above the level where the abundance of unspecified carbonate increases. The age of the sediment at the ooze-chalk transition is approximately 3 m.y. at Site 504 and 3.5 m.y. at Site 505 . If only age and burial depth were responsible for the early transformation of oozes into chalk at Site 504, it would be logical to expect the oozechalk transition at Site 505 to occur 30 to 80 meters higher in the sediment column than it does.

Although the origin of the pellets found in the coarse fractions of both sites is uncertain, the increase in their percentages above the ooze-chalk transition at Site 504 may indicate more advanced diagenesis. The higher diagenetic potential of the site may have led to more enhanced agglutination of sediment particles (mainly clay minerals and fine siliceous debris) than at Site 505.

\section{CONCLUDING REMARKS}

We used a variety of observational data, $\mathrm{CaCO}_{3}$ measurements, and bulk chemical compositions to reconstruct the history of the deposition of sediments at Sites 504 and 505 in the Panama Basin and to draw inferences about the oceanographic conditions that affected that sedimentation. The sediments consist primarily of the remains of siliceous and calcareous microorganisms and have a detrital component with a composition we have formally equated to that of pelagic clay. According to chemical analyses, there are also minor hydrogenous and metalliferous fractions, some dispersed silicic ash, and several ash beds derived from South American magmatic-arc volcanism.

Sites 504 and 505 are located near the eastern end of an equatorial belt of high sedimentation in the Pacific.
Despite being in the nearly enclosed Panama Basin, where depositional conditions may have been affected by restrictions on the influx of bottom water and the closure of the nearby Isthmus of Panama, the sites are in a critical position with respect to the surface currents that influence productivity. That is, they are near the region where the Peru Current, which hugs the coast of much of western South America, abruptly shifts to the west along the equator. The cool waters of this current warm up and become steadily more depleted in nutrients as they move to the west. Thus, sediments at the eastern end of the equatorial belt, such as those at Sites 504 and 505 , should be highly sensitive records of biological responses to changes in the temperature and nutrient supply of the water and to shifts in the geographic location of the current.

We believe that the greatest fluctuations in sediment lithology and accumulation rates at Sites 504 and 505 occurred in the late Pliocene. With the cooling of global climate, the CCD shoaled in response to an enhanced supply of colder, more nutrient-rich surface waters in the easternmost equatorial Pacific. Differences between the sites are related to the position of one of them (Site 505 ) in a graben accessible to the redeposition of sediments from nearby basement highs. The present complexity of the surface currents in the vicinity suggests that the differences may also be the result of steep gradients in surface-water temperatures, productivity, and the depth of the CCD, gradients that would have been affected by the position of the Peru Current and the equatorial countercurrent (the Cromwell current) relative to the sites. This is one of the few places in the ocean where such sharp contrasts in depositional conditions might exist within a few tens of kilometers.

In addition to fluctuating with climatic change, the carbonate and noncarbonate accumulation rates at the sites show a general pattern of decline since the forma- 
tion of basement at the Costa Rica Rift. This decline is related to the general subsidence of the sites with respect to the CCD.

Because the sites are in an area of extremely high surface productivity, accumulation rates have been sufficient to blanket the area near Site 504 with about 250 meters of sediment. The more rugged basement relief near Site 505 has caused the ponding of the sediments to quite variable depths and has left many basement outcrops in the area. The topography has directly affected the thermal and diagenetic histories of the sites. At Site 504 , the sediments form a nearly impermeable seal for the basement rocks and provide a cap for basement geothermal activity, conditions that confine the circulation of fluids almost entirely to the basement. The temperature gradients at Site 504 are therefore conductive, and because of the high sediment accumulation rates they have become so on younger crust, and at higher temperatures, than almost anywhere else in the ocean. At Site 505 , however, vigorous geothermal exchange is still occurring between the basement rocks and seawater because of the basement outcrops. Despite being closer to the Costa Rica Rift, Site 505 is cohsequently characterized by low heat flow. The sediments at the two sites thus have markedly different diagenetic features. Most notably, cherts and limestones occur in the 30 meters of sediment above the basalts at Site 504 (an interval characterized by measured temperatures of about $50^{\circ} \mathrm{C}$ ), and oozes are present nearly to basement at Site 505 (where basal sediment temperatures are only about $6^{\circ} \mathrm{C}$ ). At the latter site, the biogenic reduction of seawater sulfate is rapidly fixing pyrite in the sediments, and it has radically affected pore fluid alkalinity (Mottl, Lawrence, et al., this volume). The pore fluid gradients at Site 504 do not have the same alkalinity profile. Instead, the pore fluids are undergoing exchange with the basement formation fluids, producing strong lateral gradients in $\mathrm{Ca}^{2+}$ and $\mathrm{Mg}^{2+}$. However, there is abundant pyrite in most of the Hole 504 sediments. Early diagenesis must have been more like that at Hole 505, and pore fluid gradients must have been similar. Alkalinity would also have been controlled by the burial of organic carbon beneath rapidly accumulating sediment before it could break down in contact with oxygenated bottom waters. Ultimately, however, high temperatures, a conductive thermal gradient, and exchange with basement formation fluids overrode these initial conditions of diagenesis at Site 504 and caused cherts, chalks, and limestones to form at the base of the sediments.

\section{ACKNOWLEDGMENTS}

We thank Dr. Vesna Marchig, Dr. Helmut Raschka, and Mr. Julian Lodziak for providing geochemical data and Dr. Barbara Zobel for providing information on climatic change based on foraminiferal faunal assemblages. We also thank Dr. T. C. Moore, Dr. Constance Sancetta, Dr. Lloyd Keigwin, Dr. Ulrich von Rad, and Dr. Ellen Thomas for reviewing the manuscript and improving it substantially. Dr. Sancetta also provided the SEM micrographs. J. H. N. is grateful to Yves Lancelot, Ellen Thomas, and Miriam Baltuck, who provided guidance in interpreting the geochemical data. H. B. is grateful to the Deutsche Forschungsgemeinschaft, Bonn, which provided the travel funds that permitted his participation on Leg 69.

\section{REFERENCES}

Berger, W. H., 1970. Biogenous deep-sea sediments; fractionation by deep-sea circulation. Geol. Soc. Am. Bull., 81:1385-1402. 1973. Cenozoic sedimentation in the eastern tropical $\mathrm{Pa}$ cific. Geol. Soc. Am. Bull., 84:1941-1954.

Bischoff, J. L., Heath, G. R., and Leinen, M., 1979. Geochemistry of deep-sea sediments from the Pacific manganese nodule province: DOMES Sites A, B, and C. In Bischoff, J. L., and Piper, D. Z. (Eds.), Marine Geology and Oceanography of the Pacific Manganese Nodule Province: New York (Plenum), 398-436.

Bischoff, J. L., Piper, D. Z., and Quinterno, P., 1979. Nature and origin of metalliferous sediment in DOMFS Site C, Pacific manganese nodule province. In La Gènese des Nodules de Manganèse, Colloques Internationaux du C.N.R.S., 289:119-137.

Bonatti, E., and Joensuu, O., 1966. Deep-sea iron deposit from the South Pacific. Science, 154:643-645.

Boström, K., and Peterson, M. N. A., 1966. Precipitates from hydrothermal exhalations on the East Pacific Rise. Econ. Geol., 61: 1258-1265.

Boström, K., Peterson, M. N. A., Joensuu, O., and Fisher, D. E., 1969. Aluminum-poor ferromanganoan sediments on active oceanic ridges. J. Geophys. Res., 74:3261-3270.

Bouma, A. H., 1975. Sedimentary structures of Philippine Sea and Sea of Japan sediments, DSDP Leg 31. In Karig, D. E., Ingle, J. C., Jr., et al., Init. Repts. DSDP, 31: Washington (U.S. Govt. Printing Office), 471-488.

Carey, S. N., and Sigurdsson, H., 1980. The Roseau ash: deep-sea tephra deposits from a major eruption on Dominica, Lesser Antilles arc. J. Volcan. Geotherm. Res., 7:67-86.

Cronan, D. S., 1969. Average abundances of $\mathrm{Mn}, \mathrm{Fe}, \mathrm{Ni}, \mathrm{Co}, \mathrm{Cu}, \mathrm{Pb}$, $\mathrm{Mo}, \mathrm{V}, \mathrm{Cr}, \mathrm{Ti}$ and $\mathrm{P}$ in Pacific pelagic clays. Geochim. Cosmochim. Acta, 33:1562-1565.

Defant, A., 1961. Physical Oceanography (Vol. I): Oxford (Pergamon Press).

Donnelly, T. W., 1982. Worldwide continental denudation and climatic deterioration during the late Tertiary: evidence from deepsea sediments. Geology, 10:451-454.

Ewing, M., Heezen, B. C., and Ericson, D. B., 1959. Significance of the Worzel Deep Sea Ash. Proc. Nat. Acad. Sci., 45:355-361.

Goldberg, E. D., 1957. Biogeochemistry of trace metals. In Hedgpeth, J. W. (Ed.), Treatise on Marine Ecology and Paleoecology. Geol. Soc. Am. Mem., 67:345-358.

Griffin, J. J., and Goldberg, E. D., 1963. Clay-mineral distributions in the Pacific Ocean. In Hill, M. N. (Ed.), The Sea (Vol. 3): New York (Wiley), 728-741.

Hartmann, M., 1979. Evidence for early diagenetic mobilization of trace metals from discolorations in pelagic sediments. Chem. Geol., 26:277-293.

Hays, J. D., et al., 1972. Init. Repts. DSDP, 9: Washington (U.S. Govt. Printing Office).

Heath, G. R., 1974. Dissolved silica and deep-sea sediments. In Hay, W. W. (Ed.), Studies in Paleo-oceanography. Soc. Econ. Paleontol. Mineral. Spec. Publ., 20:77-93.

Heath, G. R., Moore, T. C., and Roberts, G. L., 1974. Mineralogy of surface sediments from the Panama Basin. J. Geol., 82:145-160.

Hein, J. R., and Griggs, G. B., 1972. Distribution and scanning electron microscope (SEM) observations of authigenic pyrite from a Pacific deep-sea core. Deep-Sea Res. Oceanogr. Alistr., 19: 133-138.

Hekinian, R., Rosendahl, B. R., and Natland, J. H., 1980. Ocean crust geothermal processes: a perspective from the vantage of Leg 54 drilling. In Rosendahl, B. R., Hekinian, R., et al., Init. Repts. DSDP, 54: Washington (U.S. Govt. Printing Office), 395-422.

Hey, R., 1977. Tectonic evolution of the Cocos-Nazca spreading center. Geol. Soc. Am. Bull., 88:1404-1420.

Keigwin, L. D., Jr., 1978. Pliocene closing of the Isthmus of Panama, based on biostratigraphic evidence from nearby Pacific Ocean and Caribbean Sea cores. Geol., 6:630-634.

1979. Late Cenozoic stable isotope stratigraphy and paleoceanography of DSDP sites from the east equatorial and central North Pacific Ocean. Earth. Planet. Sci. Lett., 45:361-382.

LePichon, X., Francheteau, J., and Bonnin, J., 1976. Plate Tectonics: Amsterdam (Elsevier). 
Lonsdale, P., 1977. Inflow of bottom water to the Panama Basin. Deep-Sea Res., 24:1065-1101.

Lonsdale, P., and Klitgord, K. D., 1978. Structure and tectonic history of the eastern Panama Basin. Geol. Soc. Am. Bull., 89: 981-999.

Lupton, J. E., Craig, H., and Klinkhammer, G., 1979. Helium-3 and manganese at the $21^{\circ} \mathrm{N}$ EPR hydrothermal site. Eos, 60:864.

Lupton, J. E., Weiss, R. F., and Craig, H., 1977. Mantle helium in hydrothermal plumes in the Galapagos Rift. Nature, 266:603-604.

McBirney, A. R., and Williams, H., 1964. Volcanic history of Nicaragua. Univ. Calif. Berkeley Publ. Geol. Sci., 55.

1969. Geology and petrology of the Galapagos Islands. Geol. Soc. Am. Mem. 118.

Menard, H. W., 1964. Marine Geology of the Pacific: New York (McGraw-Hill).

Moore, T. C, Jr., Heath, G. R., and Kowsmann, R. O., 1973. Biogenic sediments of the Panama Basin. J. Geol., 81:458-472.

Moore, T. C., Jr., Pisias, N. G., and Dunn, D. A., 1982. Carbonate time series of the Quaternary and late Miocene sediments in the Pacific Ocean: a spectral comparison. Mar. Geol., 46:217-233.

Müller, G., and Gastner, M., 1971. The "Karbonat-Bombe", a simple device for the determination of the carbonate content in sediments, soils, and other materials. Neues Jahrb. Mineral. Monatsh., pp. $466-469$.

Ninkovich, D., and Shackleton, N. J., 1975. Distribution, stratigraphic position and age of ash layer " $L$ ", in the Panama Basin region. Earth Planet. Sci. Lett., 27:20-34.

Prospero, J. M., 1981. Eolian transport to the world ocean. In Emiliani, C. (Ed.), The Sea (Vol. 7): New York (John Wiley \& Sons), 801-874.
Riech, V., and von Rad, U., 1979. Silica diagenesis in the Atlantic Ocean: diagenetic potential and transformations. In Talwani, M., Hay, W., and Ryan, W. B. F. (Eds.), Deep Drilling Results in the Atlantic Ocean: Passive Margins and Paleoenvironment, Maurice Ewing Series 2: Washington (Am. Geophys. Union), 315-341.

Schlanger, S. O., and Douglas, R. G., 1974. The pelagic ooze-chalklimestone transition and its implications for marine stratigraphy. In Hsü, K. J., and Jenkyns, H. C. (Eds.), Pelagic Sediments on Land and Under the Sea. Internat. Assoc. Sedimentologists Spec. Publ., 1:31-62.

Shackleton, N. J., and Opdyke, N. D., 1977. Oxygen isotope and palaeomagnetic evidence for early Northern Hemisphere glaciation. Nature, 270:216-219.

Turekian, K. K., and Wedepohl, K. H., 1961. Distribution of elements in some major units of the earth's crust. Geol. Soc. Am. Bull., 72:175-192.

Tuttle, O. F., and Bowen, N. L., 1958. Origin of granite in the light of experimental studies in the system $\mathrm{NaAlSi}_{3} \mathrm{O}_{8}-\mathrm{KAlSi}_{3} \mathrm{O}_{8}-\mathrm{SiO}_{2}-$ $\mathrm{H}_{2}$ O. Geol. Soc. Am. Mem. 74.

van Andel, Tj. H., Heath, G. R., et al., 1973. Init. Repts. DSDP, 16: Washington (U.S. Govt. Printing Office).

van Andel, Tj. H., Heath, G. R., and Moore, T. C., Jr., 1975. Cenozoic history and paleoceanography of the central equatorial Pacific Ocean. Geol. Soc. Am. Mem. 143.

Worzel, J. L., 1959. Extensive deep sea sub-bottom reflections identified as white ash. Proc. Natl. Acad. Sci., 45:349-355.

Zeil, W., 1979. Zür Geodynamik des Anden-Orogens. In van der Linden, W. J. M. (Ed.), Fixism, Mobilism, or Relativism: Van Bemmelen's Search for Harmony. Geol. Mijnbouw, 58:187-192. 

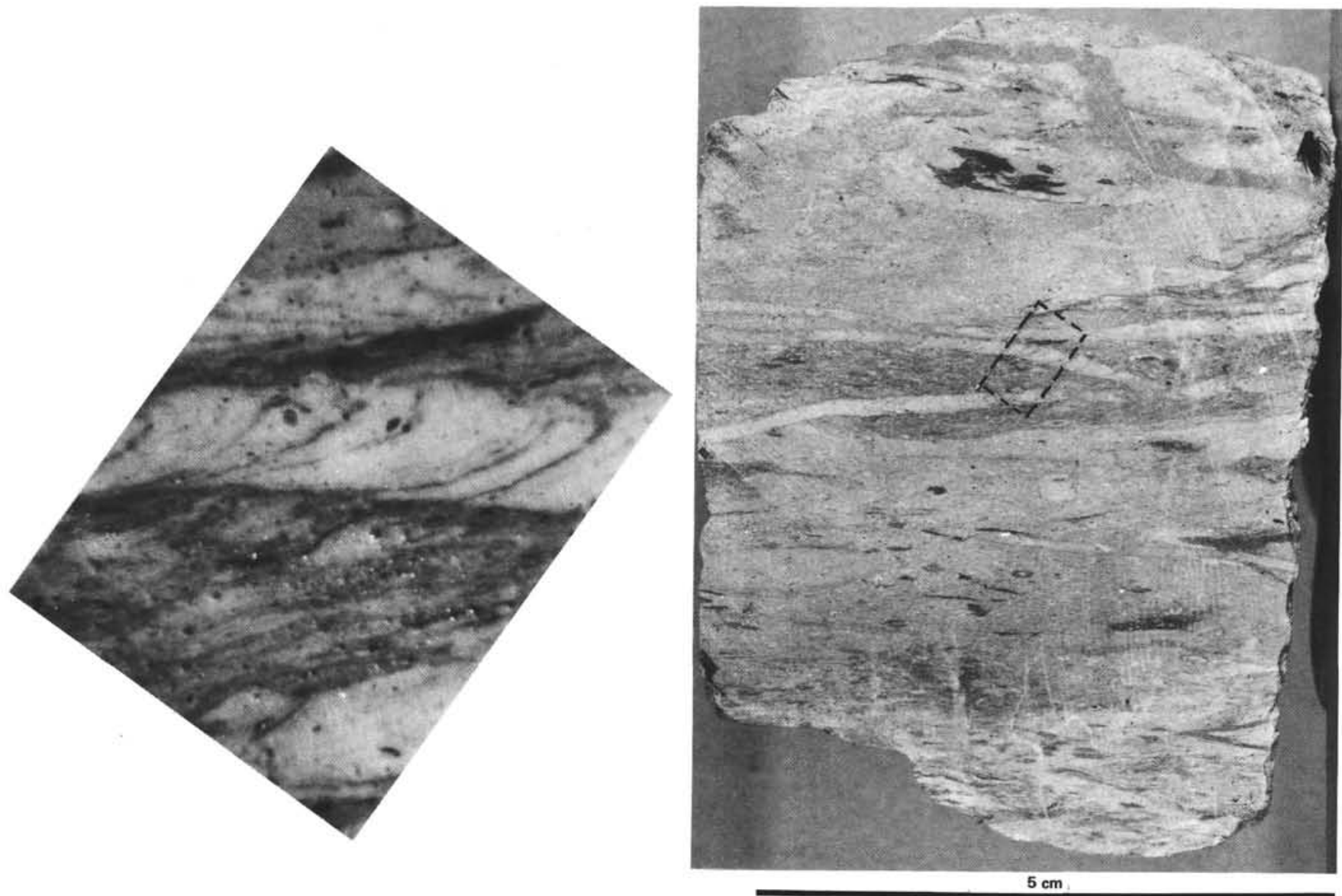

Plate 1. Compacted burrows in silicified limestone. Site 504, Lithologic Unit III, Sample 504A-4-1, 10-15 cm. Inset is incident light photomicrograph. 

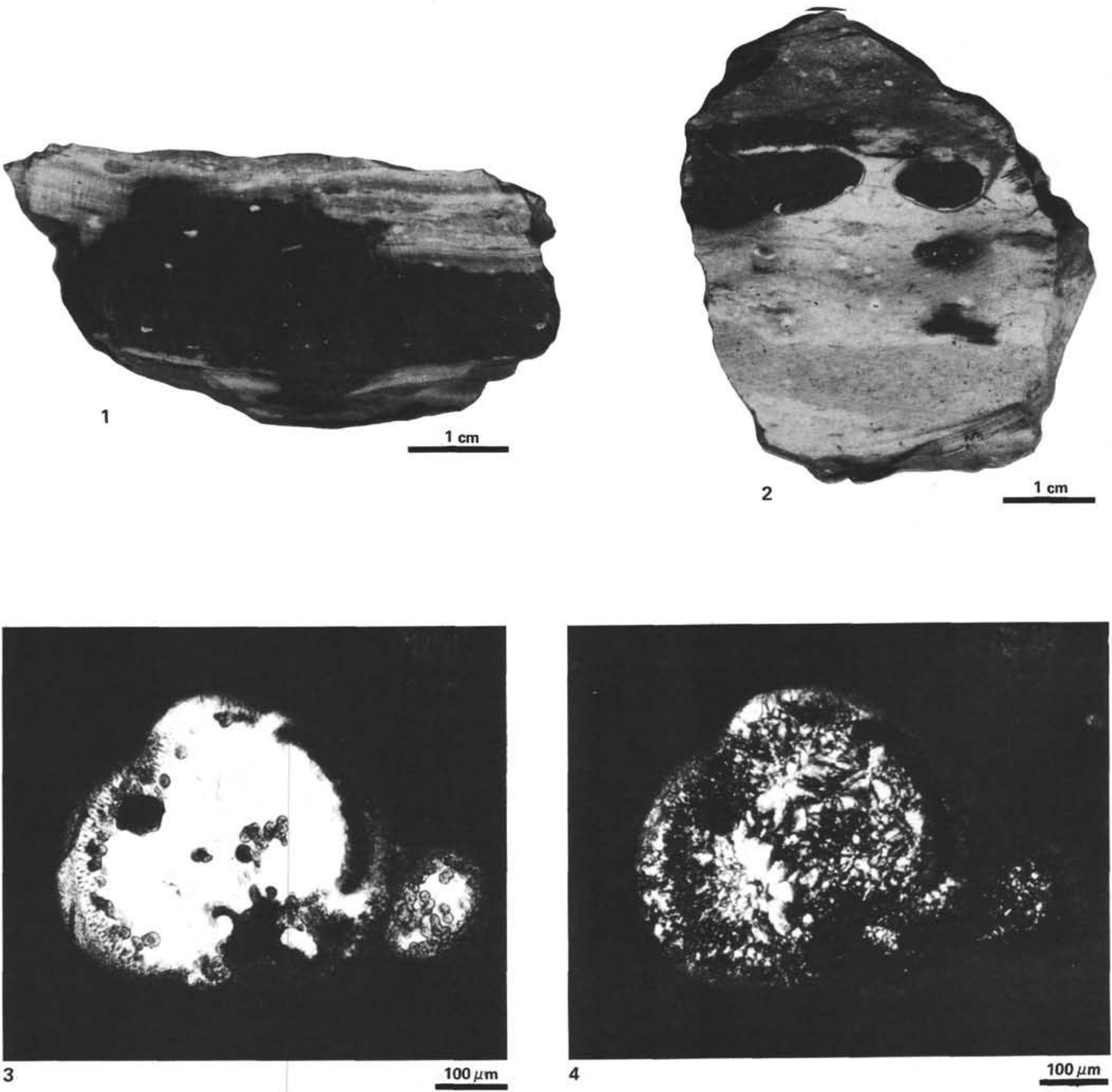

Plate 2. Features of cherts and cherty limestones at Site 504. 1. Irregular chert body within biomicrite. Sample 504A-5-1 (53-56 cm). 2. Chert nodules (dark) within biomicrite. Sample 504A-5-1 $(80-85 \mathrm{~cm})$. 3. Photomicrograph of foraminifer lined with opal-CT lepispheres and filled with quartz. Plane polarized light. Sample 504A-4-1 $(105 \mathrm{~cm})$. 4. Same as Fig. 3 except that nicols are crossed. 

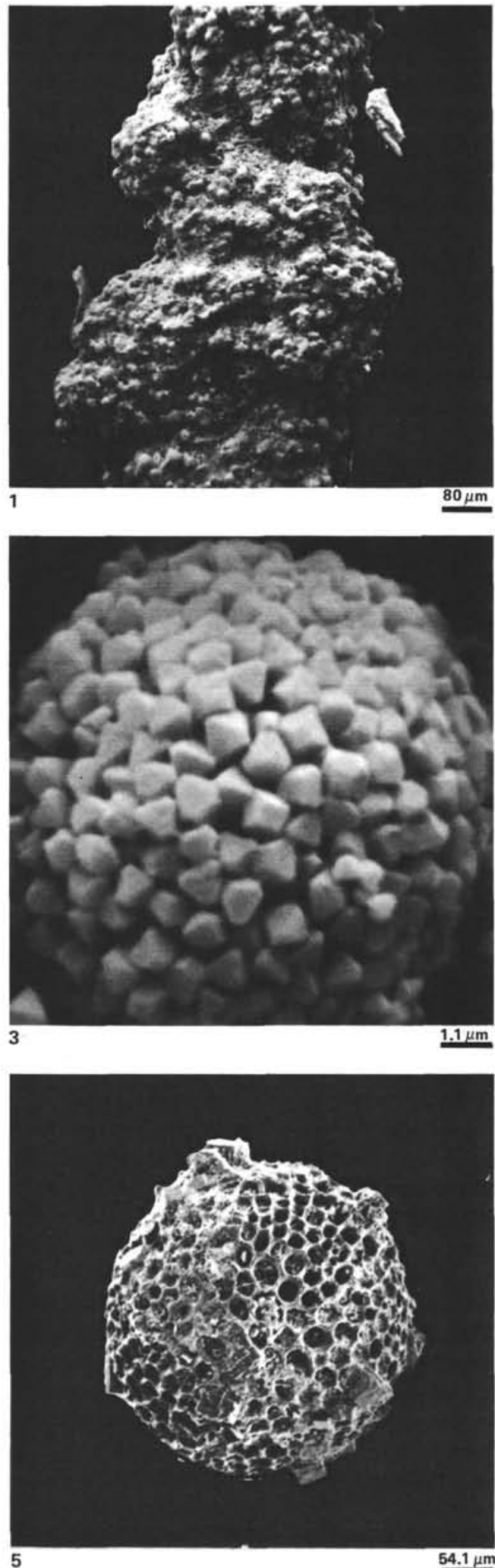
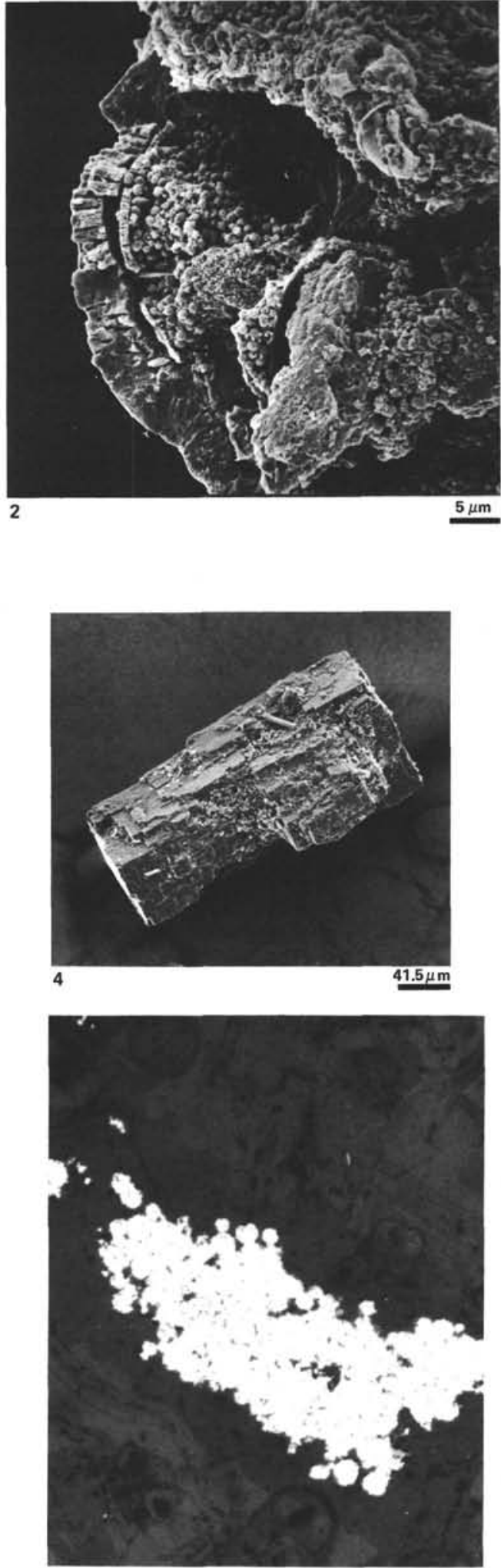

Plate 3. SEM micrographs and reflected light photomicrographs of pyrite in sediments from Sites 504 and 505.1 . Pyrite spheroids filling in worm(?) burrow. SEM micrograph. Sample 504-46,CC. 2. Pyrite filling in a foraminifer test. SEM micrograph. Sample 504-13,CC. 3. Pyrite spheroid consisting of small octahedral crystals. SEM micrograph. Sample 504-13,CC. 4. Pyrite crystal from a unique layer consisting almost entirely of large cubic pyrite crystals. Sample 504-52, CC. SEM micrograph. 5. Radiolarian test on which pyrite cubes are nucleating. SEM micrograph. Sample 504-52,CC. 6. Reflected light image of large pyrite mass in thin section of coarse fraction. Sample 504-52,CC. 7. Cubic pyrite occurring as isolated aggregates and partly intergrown with wall of foraminifer. Reflected light image of coarse fraction thin section. Sample 504-52,CC. 8. Detail of pyrite intergrowth with wall of foraminifer chamber. Reflected light image of coarse fraction thin section. Sample 504-52,CC. 9. Pyrife intergrown with radiolarian skeleton. Reflected light image of coarse fraction thin section. Sample 50452 ,CC. 10. Terminal exopodal segment from the copepod Candacia. SEM micrograph. Sample 505-1,CC. 

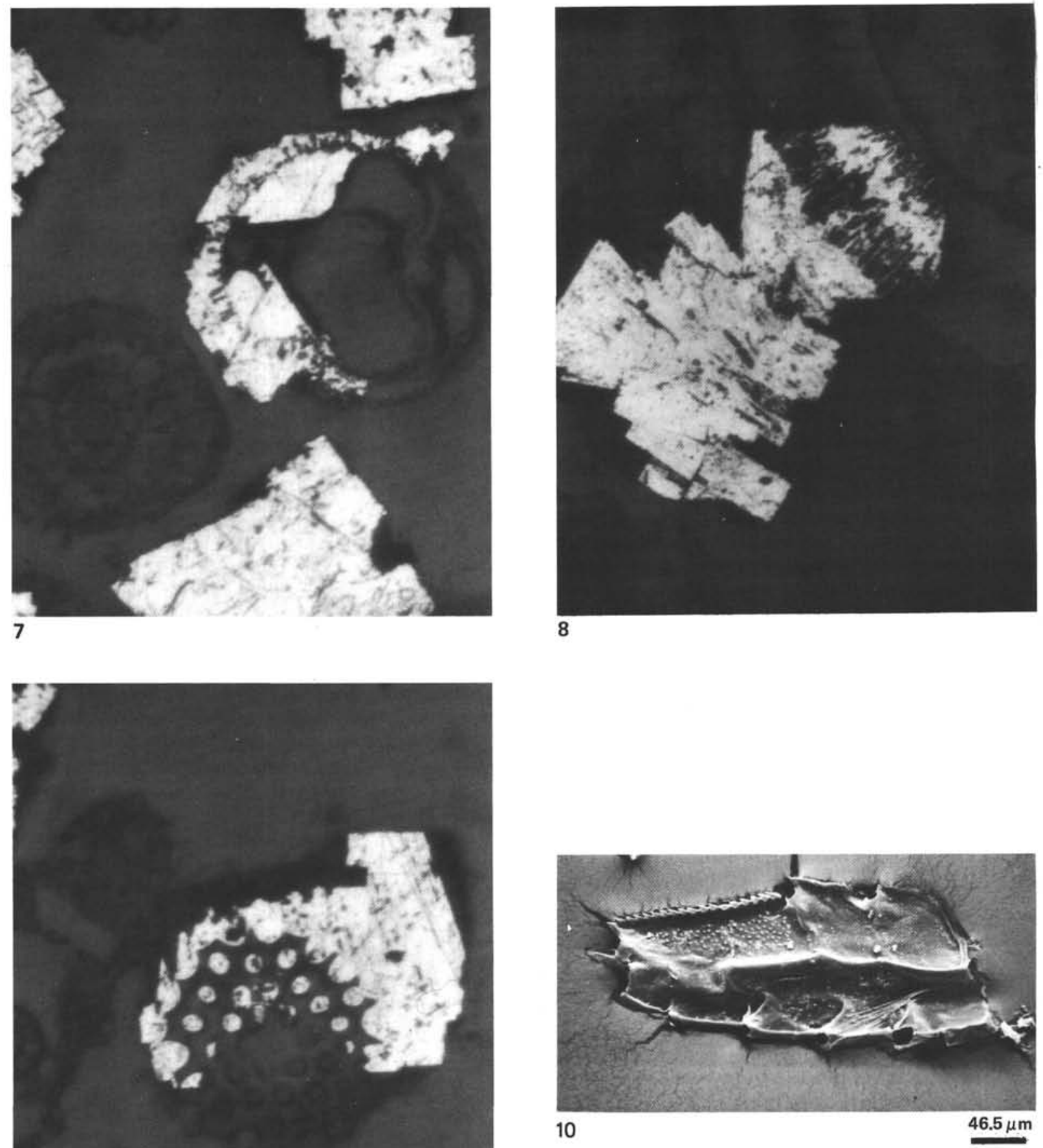

Plate 4. (Continued). 